
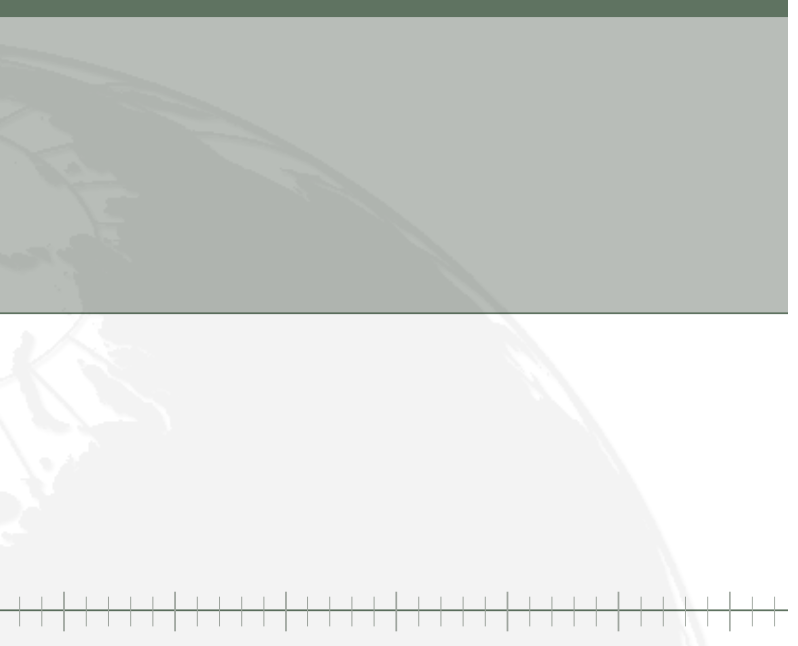


\section{Sodobni vojaški izzivi}

Contemporary Military Challenges

Znanstveno-strokovna publikacija Slovenske vojske

ISSN 2232-2825

UDK 355.5(479.4)(055)

December 2015 - 17/št. 4

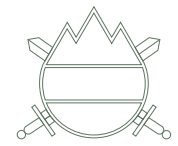

REPUBLIKA SLOVENIJA

MINISTRSTVO ZA OBRAMBO

GENERALŠTAB SLOVENSKE VOJSKE 


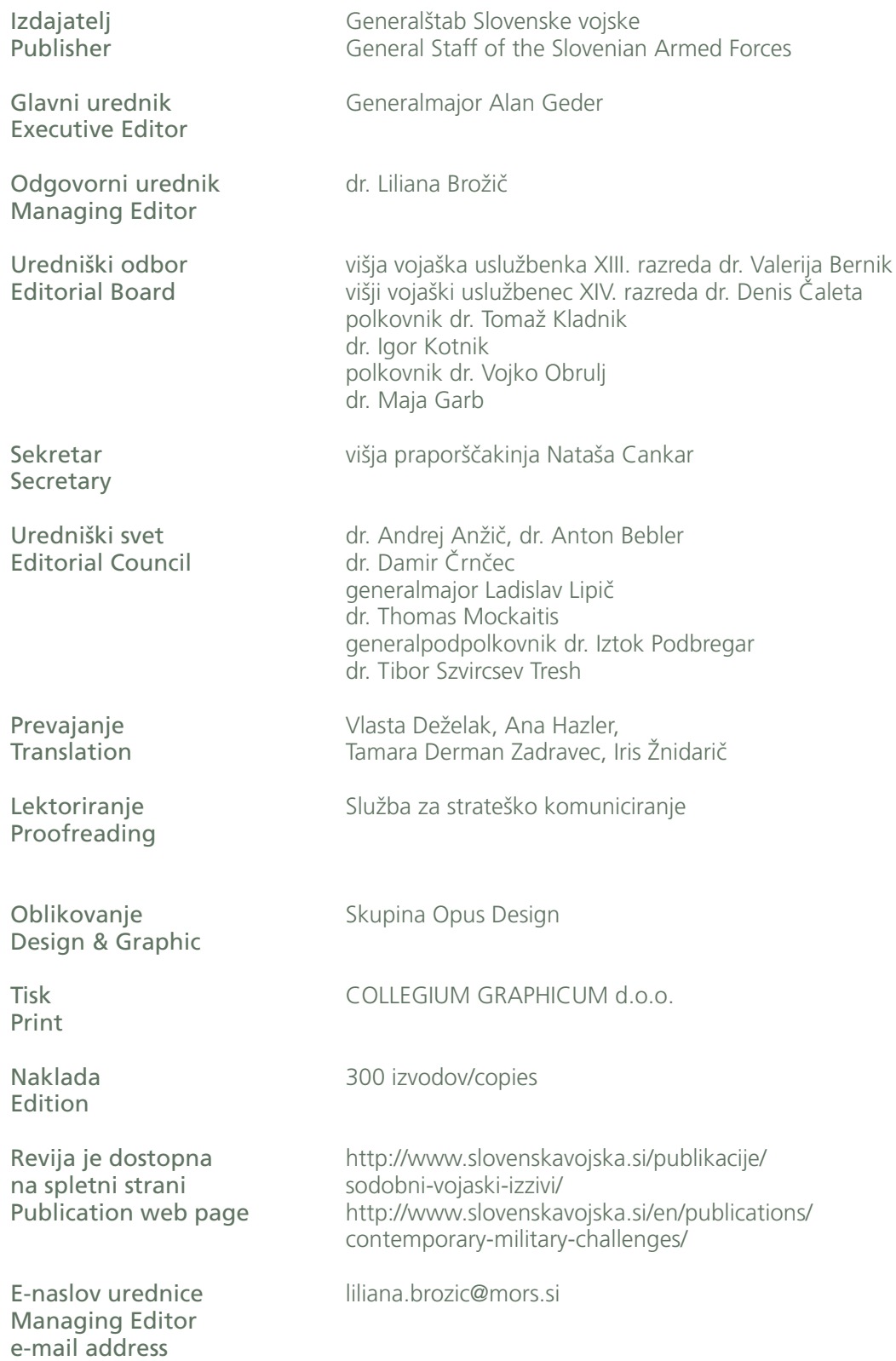

višja vojaška uslužbenka XIII. razreda dr. Valerija Bernik višji vojaški uslužbenec XIV. razreda dr. Denis Čaleta polkovnik dr. Tomaž Kladnik dr. Igor Kotnik polkovnik dr. Vojko Obrulj dr. Maja Garb

višja praporščakinja Nataša Cankar

dr. Andrej Anžič, dr. Anton Bebler dr. Damir Črnčec generalmajor Ladislav Lipič dr. Thomas Mockaitis generalpodpolkovnik dr. Iztok Podbregar dr. Tibor Szvircsev Tresh

Vlasta Deželak, Ana Hazler, Tamara Derman Zadravec, Iris Žnidarič

Služba za strateško komuniciranje

Skupina Opus Design

COLLEGIUM GRAPHICUM d.o.o.

$300 \mathrm{izvodov/copies}$

http://www.slovenskavojska.si/publikacije/ sodobni-vojaski-izzivi/ http://www.slovenskavojska.si/en/publications/ contemporary-military-challenges/

liliana.brozic@mors.si

Prispevki, objavljeni v Sodobnih vojaških izzivih, niso uradno stališče Slovenske vojske niti organov, iz katerih so avtorji prispevkov.

Publikacija je uvrščena v bibliografsko zbirko podatkov COBISS.SI in PAIS International.

Articles, published in the Contemporary Military Challenges do not reflect the official viewpoint of the Slovenian Armed Forces nor the bodies in which the authors of articles are employed.

The publication is indexed in bibliography databases COBISS.SI and PAIS International. 


\section{O SLOVENSKI VOJSKI 2012-2014}

»Profesionalnost je torej želeno idealnotipsko ciljno stanje razvoja poklica na opisanem kontinuumu, profesionalizacija pa je nikoli zares končan proces oziroma pot proti temu cilju.«

Igor Kotnik:

Profesionalizacija Slovenske vojske-

Cilj ali pot, 2012, str. 13.

\section{SLOVENIAN ARMED FORCES 2012-2014}

"Professionalism is hence the desired ideal-type end state of professional development against the described continuity, while professionalization is a never-ended process or path leading towards this goal«.

\section{Igor Kotnik:}

Professionalization of the Slovenian Armed Forces a goal or a path, 2012, p. 13. 



\section{VSEBINA}

CONTENTS

7

Liliana Brožič UVODNIK

SLOVENSKA VOJSKA 2012-2014

9

Liliana Brožič

EDITORIAL

SLOVENIAN ARMED FORCES 2012-2014

11

Igor Kotnik PROFESIONALIZACIJA SLOVENSKE VOJSKE - CIU ALI POT

PROFESSIONALIZATION OF THE SLOVENIAN ARMED FORCES - A GOAL OR A PATH

27

OBSEG IN KARAKTER SLOVENSKE VOJSKE

SLOVENIAN ARMED FORCES SIZE AND CHARACTER

47

Mojca Pešec

ALI LAHKO PROCES PROFESIONALNEGA VOJAŠKEGA IZOBRAŽEVANJA USTVARI VOJAŠKE STRATEGE?

CAN THE PROCESS OF PROFESSIONAL MILITARY EDUCATION CREATE MILITARY STRATEGISTS? 


\section{3}

Ivan Žnidar

TRANSFORMACIJSKI IZZIVI ZA VARNOST NA SLOVENSKEM MORJU

TRANSFORMATION CHALLENGES TO SAFETY AND SECURITY AT SLOVENIAN SEA

77

Branko Podbrežnik

SODELOVANJE SLOVENSKE VOJSKE V MEDNARODNIH OPERACIJAH IN NA MISIJAH V LUČI ZUNANJE POLITIKE REPUBLIKE SLOVENIJE

PARTICIPATION OF THE SLOVENIAN ARMED FORCES IN INTERNATIONAL

OPERATIONS AND MISSIONS IN THE LIGHT OF THE FOREIGN POLICY

OF THE REPUBLIC OF SLOVENIA

99

AVTORJI

AUTHORS

103

NAVODILA AVTORJEM ZA OBLIKOVANJE PRISPEVKOV

109

INSTRUCTIONS FOR THE AUTHORS OF PAPERS 


\section{UVODNIK}

\section{SLOVENSKA VOJSKA 2012-2014}

V uredniškem odboru Sodobnih vojaških izzivov smo se jeseni 2015 odločili, da za bralce pripravimo vsebine, ki so nastale med letoma 2012 in 2014 ter so povezane z razvojem Slovenske vojske. Prispevki iz te številke so že objavljeni v istem obdobju v slovenskem jeziku. S to številko želimo deliti mnenja, poglede in razmišljanja avtorjev tudi širše $\mathrm{z}$ drugimi v mednarodnem okolju, zato so prispevki prevedeni $\mathrm{v}$ angleški jezik.

Veliko let smo že člani različnih mednarodnih in varnostnih organizacij. Medtem smo pridobili veliko izkušenj na področju mednarodnega sodelovanja tako v mirnodobnih oblikah kot v mednarodnih operacijah in na misijah. Za razmišljanje o prihodnosti je pomembno imeti veliko znanja, teoretičnega in praktičnega, ter ga izmenjevati. Pri kakovostni izmenjavi znanja lahko pomaga tudi pisanje prispevkov, najprej v slovenskem jeziku. Leta 2011 sva se o pomenu pisanja in nastajanja slovenske vojaške literature v slovenskem jeziku pogovarjali z dr. Ado Vidovič Muha, slovenistko, prvo predstojnico Oddelka za slovenistiko na Filozofski fakulteti v Ljubljani. Kot je omenila, najbolj kakovostna besedila nastanejo vedno v domačem jeziku, tista, ki pa nastanejo v drugem tujem jeziku, nikdar povsem identično ne povedo, kar je avtor povedal ali pa želel povedati.

Zagotovo se s povedanim strinjamo. Prevode prispevkov v tej številki so najprej jezikovno pregledale lektorice slovenskega jezika, potem še prevajalke, zaposlene na Ministrstvu za obrambo v Slovenski vojski, ki že dolgo natančno skrbijo za besedila, ki nastajajo v obrambnem sistemu. Svoj del naloge so opravili tudi avtorji, saj so prevedene prispevke podrobno pregledali in avtorizirali.

Kadar objavimo prispevke, ki so nastali pred časom in so že bili objavljeni, se vedno postavi vprašanje njihove aktualnosti. Je določena tema že zastarela? Je imel avtor ob pisanju prav ali se je zmotil, ko je napovedoval prihodnost? 
Po prvi objavi prispevkov, ki so v tej številki prevedeni, je bilo precej različnih odzivov in komentarjev. Res je tudi, da nihče od teh, ki so komentirali, ni napisal prispevka, povezanega s to temo. Prispevki avtorjev so ostali zapisani, mnenja in komentarji nekaterih bralcev pa so se izgubili v etru. Bralci te številke imate priložnost sami oceniti, koliko so prispevki aktualni.

Igor Kotnik je v prispevku Profesionalizacija Slovenske vojske - cilj ali pot izhajal iz projekta, ki se je začel leta 2003 in se imenuje Prehod na poklicno vojsko, dopolnjeno s pogodbeno rezervo ali kratko PROVOJ, ter ugotavljal takratne razmere in se spraševal, kako naprej v danih okoliščinah in ob omejitvah, ki jih strne v devet tematskih izzivov. Ali so še aktualni?

O Obsegu in karakterju Slovenske vojske je pisal Viktor Potočnik. Veliko se je splošno pisalo o tem, koliko pripadnikov in kakšne enote naj ima Slovenska vojska. $\mathrm{V}$ tem prispevku avtor razkrije resnico. Njegova pregled in izračun sta zelo preprosta in pregledna. Že takrat smo vprašali, ali je med bralci kdo, ki se ne strinja z njim in je pripravljen o tem napisati prispevek.

Mojca Pešec in Uroš Krek sta v prispevku Ali lahko proces profesionalnega vojaškega izobraževanja ustvari vojaške stratege predstavila poglede na programe izobraževanja vojaških strategov v Sloveniji s teoretičnega in praktičnega vidika ter utemeljila potrebo po intenzivnejšem in kakovostnejšem študiju strateške teorije.

Ivan Žnidar nas je seznanil s Transformacijskimi izzivi za varnost na slovenskem morju. Pravi, da so vsestranski pristop, sodelovanje in usklajenost ali pa celo integracija različnih služb varnosti na morju nekateri od odgovorov na vprašanja racionalizacije sodobnega varnostnega okolja.

Članek Sodelovanje Slovenske vojske $v$ mednarodnih operacijah in na misijah $v$ luči zunanje politike Republike Slovenije avtorja Branka Podbrežnika osvetljuje mednarodne, politične in pravne okvire, ki vplivajo na delovanje Slovenske vojske in ga določajo v nemirnem mednarodnem okolju.

Vabljeni k sodelovanju in pisanju! 


\section{EDITORIAL}

\section{SLOVENIAN ARMED FORCES 2012-2014}

In autumn 2015, we in the Editorial Board of Contemporary Military Challenges decided to re-publish for our readers the topics, which had been first published between 2012 and 2014 and are related to the development of the Slovenian Armed Forces. The Slovenian versions of these articles have already been published before, while the aim of this issue is to share the views and thoughts of the authors also with others in the international environment. Therefore the articles have been translated into English.

For many years, we have been members of various international and security organizations. Over this period, we have gained a lot of experience in the field of international cooperation, both in peacetime structures and in international operations and missions. Looking ahead, it is important to possess abundant knowledge, both theoretical and practical, and to exchange it. In quality exchange of knowledge, writing of articles, first and foremost in one's mother tongue, can also be of assistance. In 2011, I discussed the importance of writing and producing Slovenian military literature in Slovenian language with Dr Ada Vidovič Muha, expert in Slovenian language and the first Head of the Department of Slovenian Studies at the Faculty of Arts in Ljubljana. She mentioned that the texts of highest quality were always produced in a native language, while those produced in a foreign language never identically depict what the author had said or wanted to say.

Certainly, we all agree with her statement. The translations of articles in this issue were first reviewed by Slovenian proof-readers, then by translators employed in the Slovenian Armed Forces (i.e. Ministry of Defence), who have long been closely and carefully taking care of the texts produced in the Slovenian defence system. The authors also did their share of work by thoroughly reading through and authorising the translations of their articles. 
When articles, which have been written some time ago, are re-published, there is always a question of their topicality. Is a specific topic already irrelevant? Were the author's predictions for the future when he wrote the article correct or false?

After the articles translated for this issue had been published for the first time, we received different responses and comments. But it is also true that none of those commenters ever wrote any articles to substantiate their comments. Therefore, the articles remained written down, while the opinions and comments on them were lost somewhere on air. Now, you, as the readers of this issue, have the opportunity to assess the topicality of the articles yourselves.

Igor Kotnik based his article Professionalization of the Slovenian Armed Forces - a goal or a path on the project "Transition to professional armed forces complemented with contractual reserve" (PROVOJ), which started in 2003. The author defines the present-day situation and wonders how we should proceed in the given circumstances and considering the restrictions which he divides into nine thematic challenges.

Viktor Potočnik writes about Slovenian Armed Forces size and character. A lot has already been written, in general, about how many members and which types of units the Slovenian Armed Forces should have. In this paper, the author reveals the truth. His overview and the calculations are very simple and transparent. Just as when the article was first published, we again wonder whether there is anyone among the readers who does not agree with his opinion and would be willing to write an article about it.

The article by Mojca Pešec and Uroš Krek Can the process of professional military education create military strategists presents the authors' views of the education programmes for military strategists in Slovenia both from the theoretical and practical points of view. The authors also substantiate the need for more intensive and better quality strategic theory study programmes.

Ivan Žnidar acquaints readers with Transformation challenges to safety and security at Slovenian sea. He states that comprehensive approach, cooperation, coordination and integration of various services for safety at sea provide some of the answers to the question of the rationalisation of the modern security environment.

The article Participation of the Slovenian Armed Forces in international operations and missions in light of foreign policy of the Republic of Slovenia by Branko Podbrežnik highlights international, political and legal frameworks that affect and define the functioning of the Slovenian Armed Forces in the turbulent international environment.

You are kindly invited to contribute your share and write for our publication! 


\title{
PROFESIONALIZACIJA SLOVENSKE VOJSKE - CILJ ALI POT
}

\author{
PROFESSIONALIZATION OF THE SLOVENIAN \\ ARMED FORCES - A GOAL OR A PATH
}

Kdor išče cilj, bo ostal prazen, ko ga bo našel, kdor pa najde pot, bo cilj vedno nosil v sebi.

Those who look for a goal will remain empty once they find it, but those who find a path will carry the goal inside themselves forever.

Nejc Zaplotnik, Pot

Povzetek Projekt »Prehod na poklicno vojsko, dopolnjeno s prostovoljno rezervo«, s kratico PROVOJ, je bil začet leta 2003 in predčasno končan leta 2007. Ali je bila naloga profesionalizacije SV torej že opravljena? Ocenjujemo, da proces profesionalizacije SV še zdaleč ni končan. Pot od poklicne proti zares profesionalni SV nikakor ne bo kratka in lahka, prej dolgotrajna, zavita, strma in spolzka ter polna pasti in izzivov. $\mathrm{V}$ prispevku namenjamo posebno pozornost pravilnemu dojemanju temeljnega poslanstva SV, premagovanju zapuščine obvezniške vojske, razumevanju omejitev poklicne vojske, profesionalizaciji v pogojih finančnih omejitev, profesionalni integriteti pripadnikov SV, profesionalizaciji in obvladovanju interesnih nasprotij, zunanjemu in notranjemu nadzoru vojaške profesije, profesionalizaciji prek stalnega izobraževanja ter profesionalizaciji kot nikoli zares končanem procesu. $\mathrm{V}$ tem kontekstu moramo na področju profesionalizacije poklicne SV ohraniti ustrezno čuječnost in zavzetost, preden se na nekatere nedoslednosti in nepravilnosti, na katere opozarja prispevek, dokončno navadimo oziroma ohranimo nadzor nad nekaterimi do zdaj manj uspešnimi vidiki tega procesa in njihovimi posledicami.

Ključne Poklicna vojska, obvezniška vojska, profesionalizacija, PROVOJ, profesionalna besede integriteta, interesna nasprotja, nadzor vojaške profesije. 
Abstract The project »Transition to Professional Armed Forces Complemented with Contractual Reserve« (PROVOJ) was launched in 2003 and concluded prematurely in 2007. Has thus the mission of Slovenian Armed Forces (SAF) professionalization been completed? We estimate that SAF professionalization is far from being complete. The path from career to truly professional Slovenian Armed Forces will certainly not be short and easy, but rather time consuming, winding, steep, slippery and full of traps and challenges. In the article, special attention is devoted to a proper understanding of the basic SAF mission, the overcoming of the conscription system heritage, understanding of professional armed forces restrictions, professionalization in austerity, professional integrity of SAF members, professionalization and management of conflicts of interests, internal and external control of the profession of arms, professionalization through continuous training and professionalization as a never-really-completed process. In this context, a proper amount of vigilance and commitment should be preserved in the professionalization of career armed forces, before we completely adapt to certain inconsistencies and irregularities underscored in this article and not to preserve the same level of control over some hitherto less successful aspects of this process and their consequences.

Key words Professional armed forces, conscription armed forces, professionalization, PROVOJ, professional integrity, conflicts of interest, control of the profession of arms.

Introduction Since 2000, the Republic of Slovenia has faced serious problems in the organization of obligatory military service which gave rise to deliberations on transition from the conscript to a professional armed force. In this context, the project Transition to Professional Armed Forces Complemented with Contractual Reserve (PROVOJ) was launched in 2003.

The project was divided into several sub-projects, some of which especially successfully appeased the consequences of a relatively fast transition from the conscript to a professional armed force. After five years, it was established that the project had achieved its purpose and the professionalization process was completed. The decision was based on the conviction that a career armed force is already professional and that professionalization is a goal, and not a path or process without a clearly identifiable goal.

Has thus the mission of Slovenian Armed Forces' (SAF) professionalization been completed, or would it be reasonable to be less self-sufficient and try to accomplish anything else in the field of the professionalization of the career SAF?

\section{PROFESSIONALISATION OF (NON-)COMMISSIONED OFFICERS OR THE ENTIRE ARMED FORCE?}

Until recently, it has been generally believed that the relationship between occupations and professions is dichotomous, both being characterized by opposing traits. Svetlik (1999) argues, however, that the two phenomena may not be as 
exclusive as they appear at first sight and suggests that the analysis of occupations and professions should be based on continuity. On the one side of continuity there are weakly expressed occupations, and on the other side there are ideal-type professions involving all of the implied traits. In this context, professionalization is regarded as a process where specific occupations gradually gain the increasing number of profession traits.

Professionalism is hence the desired ideal-type end state of professional development against the described continuity, while professionalization is a never-ended process or path leading towards this goal. The SAF professionalization process remains, therefore, unfinished, particularly in the context of differentiation among individual categories of military personnel - officers, non-commissioned officers, and soldiers. Officers as being one of the classic professions, beside priests, medical doctors andjudges, are undoubtedly the most professionalised part of modern military organizations, where professionalization is no longer limited exclusively to this category of military personnel.

Table 1:

\begin{tabular}{|l|l|}
\hline OCCUPATIONS & PROFESSIONS \\
\hline Marginally placed in division of work within society & Centrally placed in division of work within society \\
\hline Members are disorganized & Members have an organization of their own \\
\hline $\begin{array}{l}\text { Possess lower qualifications and receive short-term } \\
\text { training }\end{array}$ & $\begin{array}{l}\text { Possess high qualifications and receive long-term } \\
\text { training }\end{array}$ \\
\hline Experience-based activity & Activity is based on a systematic theory \\
\hline $\begin{array}{l}\text { Consumer-based selection and evaluation of their } \\
\text { products and services }\end{array}$ & $\begin{array}{l}\text { Clients accept their expertise and service as } \\
\text { unquestionable }\end{array}$ \\
\hline Market-regulated position & State-regulated position \\
\hline Activity is based on technical instructions & Activity is based on code of professional ethics \\
\hline Possess no specific occupational culture & Develop specific professional culture \\
\hline Free entry into occupational activity & Control mechanism for professional entry \\
\hline Low autonomy & High autonomy \\
\hline Poor identification with occupation & Strong identification with profession \\
\hline
\end{tabular}

Source: Svetlik, 1999.

In order to reduce differences in the officer - non-commissioned officer relationship, and even more in the officer - soldier relationship, it is not only admissible, but more and more necessary to gradually expand the professionalization concept from the officer corps across the entire military organization of developed industrial societies. This is also clearly evident in the following table, where it can be estimated that 
not only non-commissioned officers but soldiers as well are increasingly exhibiting professional qualities.

It might have been true once that soldiers without (non-)commissioned officer ranks are placed marginally in the societal division of work, are not specifically organized beyond their working environment, possess low qualifications, undergo short-term training, share no particular occupational culture, function without regard to the code of professional ethics and lack identification with their occupation, which is definitely no longer the case nowadays. Shifts are evident, but the path from a career to a genuinely full professional SAF will certainly not be short and easy, but rather time consuming, winding, steep, slippery and full of traps and challenges. Some of the major or more interesting ones will be explored in the continuation of the article.

\section{CHALLENGE NO. 1 - APPROPRIATE PERCEPTION OF THE SAF'S BASIC MISSION}

Viewed as a whole, the career SAF lacks sufficient combat orientation as a military organization ${ }^{1}$, which should be primarily directed towards the development of warfare power and combat ethos, where its stabilisation and humanitarian potential should be developed in parallel, although it is anything but that. In the long run, this may have an adverse impact on the self-image of the SAF and its members as well as the defence capacity of the state. Attention should also be given to individual occurrences of marginalisation and negative selection of career members with a distinct combat orientation or even their self-exclusion from the military organizations ${ }^{2}$ because of their frustration with an almost two-decade-long exclusion of SAF structures from real combat operations. The basic mission of any military is namely to provide realistic military force which, when other national power instruments fail to produce anticipated results, can protect, enforce and defend national interests.

Slovenian politics and public should be aware that the long-lasting obstacles in the evaluation of the training and readiness level of the professional armed force under realistic combat conditions prevent its normal development and impair its institutional integrity. Thus we are exposed to criticism that the Republic of Slovenia does not equally accept the sharing of burdens and risks in providing peace, security and stability within the international community, and hence increase the possibility of SAF's inefficient provision of national or collective defence.

\footnotetext{
Although this can no longer apply to individual SAF units trained in accordance with combat training instructions and manual, and undergoing the full operational capability system as well as appropriate verification process, we are still far away from the point when this will become common for the entire active component of the $S A F$, let alone for the members of contract reserve.

2 Termination of employment relationship in the SAF which results from employment in private security and military enterprises performing tasks in global crisis areas is still a rare case. It can with potential concentration in individual military units nevertheless severely disturb their stability and development uniformity.
} 


\section{CHALLENGE NO. 2 - ADDRESSING THE LEGACY OF THE CONSCRIPT ARMY}

The career SAF has evolved through a relatively short and soft transformation process from the conscript army, which is the reason for only partial abandonment of the legacy of the former organizational format.

Self-restraint of the Slovenian politics and public regarding the use of professional armed force in high-risk international operations and missions is well-marked. Slovenian public in particular behaves as if the Republic of Slovenia has not undergone transition from the conscript military that is understandably highly sensitive about any victims, to a totally different format of a career army. As the entry into a professional armed force is voluntary, the character of which is expeditionary rather than territorial, its members are exposed to a higher risk as early as at the beginning. I do not wish to be misunderstood - nobody wants to have victims. However, the ever-present fear of politics and public about the issue of victims should not have a negative impact on the implementation of national interests or military professional qualifications of SAF structures for operations in international operations and missions.

In the professional SAF structure, the ratio among individual categories of military personnel is still a clear indication of the legacy of the conscript army. Similarly, the target ratio of $1: 2: 5$ between officers, non-commissioned officers and soldiers laid down in planning documents has still not been attained. Achieving a more appropriate ratio is a highly demanding and long-lasting task, which must be maintained and sought by virtue of its significance.

The transition from the conscript to a career armed force led to a relatively quick downsizing of operational and military capabilities envisaged as part of the organization and mobilization development. Despite disbanding some of the commands, such as the military territorial commands ${ }^{3}$, the SAF command structure nevertheless remains oversized, not in terms of the number of commands but rather with regard to their manning levels and process duplication. Operational combat capabilities of the SAF career force are comparatively too moderate.

With the abolition of the conscript army, the flow of the cheap workforce of conscripts doing military service came to an end. It is hence unacceptable to engage expensive career soldiers, for instance military police, not only because of their salary, but also due to the investment into their education and training, for simple tasks, such as reception service instead of outsourcing cheaper services.

Loyalty in a modern career army does not necessarily mean absolute subordination to non-appellate authority. In accordance with new Military Doctrine (2006) principles,

\footnotetext{
It becomes increasingly evident that their disbandment was not only illegal, but it also had a negative impact on maintaining SAF's integration into civilian environment, which was often discussed by the author of this article and others.
} 
the loyalty of subordinates to their superiors is reflected in the fulfilment of orders which implement the mission of the Slovenian Armed Forces, promote the interests of the Republic of Slovenia and strengthen its reputation in the international community. Loyalty is demonstrated through mutual trust and respect, as well as disciplined and accountable accomplishment of duties, and not through blind obedience and submissiveness, which is still not a widely applied practice in the career SAF.

An important issue for the career SAF is the inappropriate organization of the daily working time, which can be partly related to the conscript army and the status of military personnel equal to civil servants in public administration, but also to the unwillingness of the SAF to transform as an institution into a conventional career armed force with a more functional working rhythm, allowing more flexibility within the work code regulating public administration.

An ever-present challenge for career armies is still the status of career military personnel upon termination of their contract relationship for a limited period of time or completion of age limit for professional soldiers (NCOs and COs excluded), which is set at 45 years in the Republic of Slovenia. When addressing this challenge, an adequate balance must be sought among the interests of individuals, the military organization, the state and the society. Seeking appropriate consensus in the interim period is impaired due to past experiences of the conscript army, when professional military service contracts for (non-)commissioned officers were, as a rule, concluded for an unlimited period of time, and the employees were not confronted with the challenge of a second career and a new job in the civilian labour market at the half of their length of service. The market is (still) unfavourable to former career military personnel compared to some countries with long-standing experiences of a career army. As a balanced and sustainable development of a career army is inevitable necessitated by contract relationship for a limited period of time, the challenge should be given more attention and adequate social mechanisms should be provided to reduce uncertainty and potential dissatisfaction of career military personnel.

\section{CHALLENGE NO. 3 - UNDERSTANDING THE LIMITATIONS OF THE CAREER ARMY}

It is an undeniable fact that a career army can only be sufficient as a peacetime military instrument of the Republic of Slovenia. This, however, does not mean that it would be rational to supplement it with conceptual or even structural solutions following the very example of the former Territorial Defence Forces. We namely live in a new military strategic reality, which allows only reasonable use of former experiences and not their copies.

This on the other hand does not imply a non-appellate and uncritical belief in the all-mightiness of the concept of collective defence. It needs to be understood that collective defence by definition is just a synergy set of national defence. Each state should be capable of ensuring its own military security and contributing at the 
same time to military security of allies and partners. Since in the event of extreme deterioration of security situation in the international community this objective cannot be met nationally solely with the help of career military, nations have to look for appropriate system and organization solutions facilitating the establishment of larger military capabilities in order to counter potentially bigger, intensified and long-lasting military threats.

Slovenia is therefore developing a concept of military strategic reserve which would enable reorganization and growth of peacetime defence and military capabilities into those adequate for wartime. In this regard, comprehensiveness of social endeavours plays a very important role and should be given particular attention due to the specific relationship between the career military and civilian society. The SAF still ranks high in public opinion polls on trust, although the delineation process of the career military from the civilian society is clearly perceived. ${ }^{4}$ The adverse effects are still not visible for the time being, but at time of ease and complacency as well as ignorance of this challenge a sudden tectonic slide of social acceptability and popularity of career military may occur with little chances for subsequent mending.

\section{CHALLENGE NO. 4 - PROFESSIONALISATION IN SPITE OF AUSTERITY MEASURES5}

The purpose and mission and tasks of the SAF, i.e. the ends of the defence system and the SAF, are clear. Since the means are, however, increasingly limited, we have for several years reminded about the need for deep reflection on the established ways of implementing national security and defence objectives of the state, and the search for new ones.

Owing to dynamic changes in the strategic environment, the defence sector reforms are a cyclic necessity, which has been this time additionally spurred and impaired at the same time due to limited means. In a few years' time, it will probably be impossible to achieve the planned level of defence expenditure and its adequate structure.

As a result of a recent transition to a career armed force, this represents an even more difficult situation for the Republic of Slovenia with the transition from a workingintensive form of conscript army to a financially intensive defence concept. This does not mean that the career aspect is in nominal terms costlier than the conscript system which is based on quantity, but its effectiveness relies more on armament

\footnotetext{
4 The indicators of this process are as follows: through transition from the conscript to the career army, the system-based entry of the part of the population into the military through military service and participation in military exercises was suspended, the number of barracks was reduced, all military facilities had been removed from certain parts of the country (Bela krajina region, Koroška region, Soča valley region), military territorial commands (VTP) were disbanded, and the defence system, the SAF and civilian society activities (societies of particular importance for defence, logistic support of public events etc) received less support.

5 See also Kotnik, Igor (2012). Zmanjševanje finančnih sredstev za obrambo - Naloge enake, denarja manj. Obramba Magazine, February 2012, 4-8.
} 
and equipment quality and availability of financial means for development and investment (modernization). Without the necessary financial means, the majority of positive effects of transition to a career armed force will vanish over the mid-term, while over the long-term the underfunded career SAF may turn into a caricature.

Therefore, it is necessary to make a resolute deviation from the false impression that small countries can have everything the big ones have, be it in terms of the form and structure of defence capabilities. If such logic was partially acceptable during economic activity, it has become entirely unacceptable and irresponsible in the time of financial crisis and economic recession. The Republic of Slovenia should, similarly to NATO, develop generic planning security and defence scenarios and the associated requirements for defence capabilities of adequate quantity and quality in roder to pursue and defend national interests and ambitions during peacetime, emergency situations and wartime, which would be based on strategic political and development-guiding documents and credible analysis of long-term external security threats posed to the Republic of Slovenia. In the next step, a comparison of the needed and available defence capabilities should be carried out to identify their surpluses and gaps, determine priorities and abandon unpromising capabilities allowing us to free the financial means required for the maintenance of the existing prioritized military capabilities and development of the urgently needed niche capabilities.

It should be understood that the time of austerity measures provides an excellent opportunity for investment into the organizational software, where along with various forms of education, training and exercises consideration should be particularly given to the improvement of psychosocial atmosphere and leadership as well as to the identification of innovative conceptual and doctrinal solutions which in spite of limited resources for the procurement of advanced armament and technical systems can function as multipliers of increased operational effectiveness of military capabilities. ${ }^{6}$

\section{CHALLENGE NO. 5 - PROFESSIONAL INTEGRITY OF SAF MEMBERS}

Professionalism also involves assuming responsibility for one's own professional and social conduct. This includes professional, i.e. military in our case, and general social ethics and morale. According to Drinovec (2002), it is not only about the principle of doing good and not doing bad, but doing the right thing also for the duty and avoid doing wrong.

Formally, the area of professional military ethics in the Republic of Slovenia is adequately regulated in the Code of Military Ethics of the Slovenian Armed Forces (2009). The issue is, however, whether this ethics has already been fully internalised and whether it, consequently, as professional morale of SAF career soldiers fully

\footnotetext{
${ }^{6}$ At least minimum financial means should be provided for the procurement of test examples of key advanced armament and technical systems as well as for training of key personnel responsible for their analytical use, as we should not lose contact with the development in defence field, if we are unable to follow it adequately.
} 
meets ethical standards through their judgment and activity. I believe that in the Republic of Slovenia functional military professionalism is quite well developed, although there is still significantly more room for development in the field of ethical and moral military professionalism. Let me substantiate this opinion with two examples: professional values and professional integrity.

Drinovec (2002) points out insightfully that the mission of professions is not only to protect vulnerable population, but also vulnerable social values. According to Military doctrine (2006), the values of the Slovenian Armed Forces are rooted in general civilization values, the values of Slovenian society and specifics of the military activity character.

The fundamental common value shared by the members of the Slovenian Armed Forces is patriotism, on the basis of which the military also develops military values, such as honour, courage, loyalty, comradeship and commitment. It is probably generally agreed that these values are among the more vulnerable also in our society, hence the example set by military professionals in their protection and strengthening becomes even more important.

Although professions entail the required collective responsibility, even when pursuing and protecting vulnerable institutional and social values in the military organization, comradeship should not be in the service of concealing and protecting the individuals incapable of meeting of its ethical and moral standards, which brings us to the domain of professional integrity.

Rutledge (2011) believes that in terms of respecting moral principles people can be divided into two groups - those respecting and those ignoring the principles. The first group has developed a moral core composed of fundamental values. If these values represent a consistent whole in an individual, they are referred to as integrity. People, however, with no moral core, possess no personal integrity and behave in accordance with moral relativism. As already explained, definitions of professionalism commonly refer to the required existence of ethical codes, although it should not be ignored that the influence of ethical code is only as powerful in practice as it is powerful the moral foundation of an individual.

\section{CHALLENGE NO. 6 - PROFESSIONALISATION AND MANAGEMENT OF THE CONFLICT OF INTEREST}

It is often assumed that professionalism involves quality in a non-appellate manner, or, inversely, that poor-quality services are often considered unprofessional. Professionalism is aimed at developing and providing goods and services of special quality, which meet the key needs of people (Svetlik, 1999), in our case (military) security. When fulfilment of the key needs requires subordination of individual needs and interests, we are entering the field of altruism which is also one of the characteristics of professions. 
The above, although in a more moderate form, is also summed up in the SAF Code of Military Ethics SV (2009), where SAF members »/.../ adjust their personal interest and goals to the interest of their unit and the Slovenian Armed Forces« In terms of pursuing individual interest goals, this is by all means a highly interesting dynamics which cannot be clearly established in each case. Depending on the character of individual's interests and goals, it can involve subordination, adjustment or just coordination, yet it is, by all means, unacceptable and wrong to give individual and narrow group interests and goals greater preference over general collective, institutional, state and national interests. The establishment level of the latter principle within the SAF is a matter of subjective consideration, although some objective indicators, such as the absenteeism level, particularly during prolonged field exercises, imply quite some development potential in this area.

Managing the conflict of interest represents one of the more complex professional development areas, since through the professionalization process clients increasingly regard professional expertise and services as unquestionable, thus justifying the expectations and demands of the representatives of a specific profession for a more advantageous social position. At this point specifically, maturity and social responsibility of a profession becomes evident, at the same time raising the question of its willingness to be exposed to various forms of external and internal control in as transparent and unforced manner as possible.

\section{CHALLENGE NO. 7 - EXTERNAL AND INTERNAL CONTROL OF MILITARY PROFESSION}

According to Drinovec (2002), professions are beyond the limit of necessity inclined to exploit the monopoly of maximizing economic and other interests of their members, potentially leading to decline or weakening of professionalism as a result of omitting control within the profession.

Occupations are typically controlled externally, while professions are at the same also exposed to internal control. In case of military profession, the external control is two-fold - the control of the state is performed through various institutionalized mechanisms, and the social control through public opinion. One of the main priorities of the military profession is, therefore, to maintain appropriate relations both with the political state and civilian society, where confidence of the state and society in military profession is of fundamental importance.

Such confidence depends primarily on the appropriacy of military profession activity and effectiveness of fulfilment of functional and social imperative, which demands from the military organization to develop and apply appropriate self-regulatory mechanisms of internal control. This should also involve adequate disciplinary and improvement mechanisms, and in the extreme case also the exclusion of those members who have failed to meet or respect professional standards. 
The key challenge is to ensure appropriate synchronization of external and internal control mechanisms and guidance for a career army as being a highly complex social structure in its character. If external control is too strong, problems may arise as a result of impaired professional autonomy, or in the opposite case, a career army may become a highly unpredictable and unmanageable social structure. It can be concluded that internal military professional control and SAF guidance are still not fully developed in terms of function and structure, and the commanders still lack an appropriate set of tools of positive and negative sanctions to help them efficiently manage the career army. ${ }^{7}$

\section{CHALLENGE NO. 8 - PROFESSIONALISATION THROUGH CONTINUING EDUCATION}

Military profession, or increasingly the profession of arms, has been exposed to a continual adjustment and modification need, which stems from the changing political security, technological, military strategic, doctrinal and social determinants of contemporary world. Svetlik (1999) believes that professions have to develop appropriate mechanisms of internal adjustment to respond to changes in the environment, with those of education bearing the major importance.

Owing to the speed and scope of changes faced by professions, Svetlik argues (1999) that it is increasingly impossible and unreasonable to train new members for the accomplishment of concrete professional tasks during their initial training. He suggests instead to focus the initial training on general and widely applicable qualifications and knowledge providing a solid basis for subsequent continuous adjustments to the changing professional work.

Maybe some would oppose such a view, which however does not change the fact that the ability for efficient performance of professional work demands from all military personnel to participate in continuing education. It is essential to understand and accept that continuing education is no longer an advantage for officers and non-commissioned officers, but rather a necessity for soldiers as well. In the long run, the mere training and exercises will not, without appropriate education, equip them satisfactorily with the competences needed for task accomplishment in the increasingly complex environment sensitive to mistakes. A leap in philosophy cannot be immediate, but rather demands a gradual and comprehensive approach, where a personal professional example of the superiors and colleagues will be supplemented through formalized educational topics.

The only SAF disciplinary body is the Chief of the General Staff, who may transfer his authority to commanders, originally without this power. In contrast to the practice of the majority of career armies, SAF commanders cannot order custody for soldiers and also have more limitations in terms of remuneration than their international counterparts. 


\section{CHALLENGE NO. 9 - PROFESSIONALISATION AS THE PATH WITHOUT END}

The project group in charge of the project Transition to Professional Armed Forces Complemented with Contractual Reserve (PROVOJ) was established in May $2002^{8}$ with the task of launching the project no later than in February 2003. In accordance with the final report of the project PROVOJ (2009: 15), the SAF professionalization was aimed at fully addressing the issues of the emerging career army in the following 17 areas of sub-projects:

- PP 1 and 2: Project management and management plan,

- PP 3: Recruitment measures,

- PP 4: Manning of the Slovenian Armed Forces,

- PP 5: Military service - retention and dismissal,

- PP 6: Care for the welfare of SAF members,

- PP 7: Dismissal of SAF members from military service,

- PP 8: Education and training,

- PP 9: Equipping with weapons and military equipment,

- PP 10: Further adjustments of legislation,

- PP 11: Infrastructure adjustments,

- PP 12: Funding,

- PP 13: Formal and legal advancement of military professions,

- PP 14: Cooperation with other ministries,

- PP 15: Slovenian Armed Forces and civilian environment,

- PP 16: Leadership,

- PP 17: Cooperation with economic sector.

Given the previous reasonable arguments of describing professionalization as a path and not as a goal, it may be agreed with the conclusion that it is a unique project (Final project report, 2009: 18, 23), yet not at all with a statement that it is a timely limited process. Moreover, the project, which was initially planned for the period up to the end of 2010, was officially concluded already at the end of 2007 without reaching some of the major project goals. The Final project report (2009: 42-90) lists the following working packages (ID) and task (N) or object (PR) goals:

- PR 3.19: Satisfied SAF members ${ }^{9}$;

- N 4.2: Recruitment and selection of candidates will be carried out in the manner to achieve the end states of the manning level of permanent and reserve SAF structures;

- N 4.7: Units manned with contract reservists will be manned with former active duty members;

\footnotetext{
Document-no. 802-00-8/2002-1, dated 28. 5. 2002.

9 Although the Service in the Slovenian Armed Forces Act addresses some of the negative trends, notably salary stagnation and welfare care, the following challenges still remain unresolved: emplyoment relationship for a limited period of time, distance from work, gap between expectations and reality (e.g. initial information and subsequent workload, prolonged abseentism etc.) and negative trends of labour market in terms of increased competitive offer of more attractive or safer jobs (Final report PROVOJ, 2009: 43). The latter is less evident during the period of austerity measures and economic recession, while all other trends are still topical.
} 
- N 5.20, PR 5.19: Agreements on employment of former SAF members will be concluded with other ministries and major employers;

- PR 5.6: Conditions will be established to address the lack of appropriate personnel in SAF units and commands;

- PR 5.18: The organization of professions of former SAF members will be established;

- ID 651: Medical care will be provided;

- N 6.3, PR 6.3: The self-help system for family members will be introduced;

- N 6.6, PR 6.5: In accordance with resources, basic medical care will also be provided for family members of SAF members as part of the military medical service;

- PR 8.5: The acquired rights for issuing official deeds, certificates of education and qualification will be treated equally as those of related civilian professions;

- PR 8.6: Education and qualifications acquired during education and training in the SAF can be utilized for jobs upon the termination of employment in the SAF;

- N 11.7: Priority in adjustments or construction of housing units will be given to single members;

- ID 378: Educational programmes for standard professional knowledge and skills will be drafted and verified;

- PR 13.5: Arrangements will be made for the issuance of certificates and licences to all SAF members.

The Final project report (2009: 47) also states that the implemented task and object goals of the project have not been yet introduced into life and work of the constituent units of the Ministry of Defence and the SAF, or at least not sufficiently enough.

All of the above - the early completion, unsuccessful implementation of a significant number of major task and object goals as well as conclusions on incomplete implementation of some PROVOJ results in practice - leads us to consider the necessity of the project continuation, which is rather cautiously and secretly, yet undoubtedly, also indicated on page 27 of the Final project report. In the table presenting the final stage of the PROVOJ project, the Final report PROVOJ is followed by another two, Continuation of professionalization programmes and PROVOJ II. As specific areas of professionalization requiring further or continued attention, there was an explicit mention of salaries, infrastructure, family, welfare, leadership, relations, adjustments of legislation and SAF promotion, which, based on daily experiences, could be at least expanded with the career path, care for welfare of members, adjustments of legislation, cooperation with ministries ${ }^{10}$, complete system of criteria and programmes for selection and education and training in military leadership ${ }^{11}$ and relations with civilian environment ${ }^{12}$.

\footnotetext{
${ }^{10}$ Following the example of some other countries with career armies, it would be at least sensible to seek agreement with other ministries and introduce practice, whereby a minimum of one completed contract period in the role of professional soldier would be the required career step for employment in some other state instiutions or professions.

${ }^{11}$ Example: A team-department for military leadership development is established, whose formation table and size of personnel, however, does not facilitate complete implementation of the tasks set. (Final project report, 2009: 93)

12 This is particularly important in the context of, first, limitations of the role of military territorial commands and, subsequently, their disbandment as well as social expectations and the increasing pressure on reducing defence expenditure.
} 
The Final project report becomes more explicit about the need to continue the process of professionalization in the SAF on page 97: »We believe that SAF professionalization is a process requiring the further goal-orientation and implementation through all necessary projects« In the continuation of the final report, emphasis is laid upon the argument that professionalization mind-set is still inadequately introduced into the work of the Ministry of Defence and the SAF General Staff, necessitating the continuation of project work in order to achieve a proper perception and understanding of career military and military professionalism in all SAF structures and other environments which influence the status and functioning of the military organization.

This involves in particular the aspect of so-called functional professionalization ${ }^{13}$ or the development and introduction of an appropriate way of thinking, planning and functioning, which, due to the inertia of human mind, represents one of the major challenges of any large-scale and profound system-wide changes, what transition to a career army and professionalization definitely is. This aspect of professionalization is especially important during this period of restricted defence funds, as the changed way of thinking commonly requires only little resources compared to its general positive effects.

Conclusion A lot has been achieved along the twenty-year-long path from the Territorial Defence Forces, through the conscript to the career SAF and its professionalization, but the time has not come yet to rest on our laurels.

As any other social process, professionalization of a military organization is an oscillation. It should, therefore, be carefully controlled and guided as well as ensured that the internal oscillation is as little as possible and that the main activity despite occasional problems and stops stays predominantly positive.

At the beginning of the third decade of our independent state it is time to re-evaluate whether the development of defence and military capabilities has indeed reached the expected stage given the normative, development-guiding and planning documents as well as military-strategic and social reality. We should be honest in explaining why we maybe somewhere else, not to judge about the past, but rather to prevent repetition of mistakes in the future. Encouraged by the negative impact of economic recession and financial crisis reflected notably in the reduction of financial means for defence needs of the state, we have to be prepared to take decisive, yet prudent action.

Most likely we have found ourselves at the point when at least for some time we will have to get used to the idea of a less ambitious vision of the future SAF development in terms of its modernization and financial means. At the same time, all of its positive potential which has been over ignored in the past needs to be skilfully activated.

\footnotetext{
13 The PROVOJ project took into account and specifically emphasized the difference between functional and structural professionalisation, which enables the creation of adequate personnel, materiel and organizationalstructural base of a military organization.
} 
The potential should be directed towards a determined quest for ways and methods, tolerant to minor mistakes and time- and circumstance-adequate, for accomplishing mission and tasks of the SAF.

In this context, professionalization of career military should involve the maintenance of appropriate vigilance and commitment, before finally yielding in to some inconsistencies and irregularities pointed out in the article, and control of some of the previously less successful aspects of this process and their consequences.

The Slovenian Armed Forces represent the operational core of Slovenia's defence system. Based on full social efforts, appropriate conditions for the further development of military professionalism should be established. The foreground of these endeavours, however, should be reserved for all those professionally dealing with defence matters, in particular the current and future SAF members, united and motivated by the motto: »The SAF and me - together on the way to professional excellence! $\ll^{14}$

2. Kodeks vojaške etike Slovenske vojske, 2009. Uradni list RS, št. 55/2009 z dne 17. 7. 2009.

3. Korez, Simon, 2012. SV s profesionalno odličnostjo in stabilnostjo v novo desetletje. Revija Slovenska vojska, št. 3, 9. 3. 2012, 18.

4. Kotnik, Igor, 2012. Zmanjševanje finančnih sredstev za obrambo-Naloge enake, denarja manj. Revija Obramba, februar 2012, 4-8.

5. Rutledge, Andy, 2011. Design Professionalism, Online Edition ISBN 978-0-9836578-2-8.

6. Svetlik, Ivan, 1999. Sodobni izzivi profesionalizmu. Knjižnica 43 (1999) 2/3, 7-18.

7. Vojaška doktrina, 2006. Furlan, Branimir (in drugi). Defensor, Ljubljana.

8. Zaključno poročilo projekta PROVOJ, Ministrstvo za obrambo-Generalštab SV, številka 802-00-4/2005-166, z dne 29. 5. 2009.

\footnotetext{
14 The text is an adaptation of Korez's (2012) highly attractive proposal of a new SAF motto: "The SAF through professional excellence and stability towards a new decade." The initial proposal was a little shortened and simplified, with stability being a necessary element of professionalism. Moreover, the modified motto involves a development aspect, as a path leading to a goal, at the same time through »me incorporating the idea of personal involvement and responsibility. As such, the motto follows the argument of Korez (2012) even closer than the original one, and it functions on two levels: as a recognition of all of the employed staff for co-creating professional excellence, and as encouragnment to those contemplating to join the SAF on its way towards excellence.
} 
Viktor Potočnik

\section{OBSEG IN KARAKTER SLOVENSKE VOJSKE}

\section{SLOVENIAN ARMED FORCES SIZE AND CHARACTER}

Povzetek Besedilo obravnava vprašanji o obsegu in karakterju Slovenske vojske (SV). Že nekaj časa se namreč pojavljajo zamisli o nadaljnjem zmanjševanju stalne sestave SV, ki zaradi omejenih finančnih sredstev dobivajo še dodaten zagon. V članku je kratek zgodovinski pregled obsega oboroženih formacij slovenskega naroda v luči izpolnjevanja nalog SV, kot so zapisane v Zakonu o obrambi (ZoObr). Obravnavam tudi karakter SV in osrednjega vira njene bojne moči, in sicer pehote. Vojske v zavezništvu in širše poznajo več tipov pehote, kar je treba upoštevati, ko razmišljamo o tem, kakšno pehoto bomo v SV imeli. Seveda se zavedamo finančnih omejitev, ki jim je SV izpostavljena, zato v sklepnem delu predstavljamo nekaj predlogov, kako uresničiti predlagana obseg in značaj SV, ki so namenjeni dodatni razpravi in bi bili potrebni bolj poglobljene analize.

Ključne Obseg oboroženih sil, Slovenska vojska, Nato, pehota, stalna sestava, vojaška besede strateška rezerva.

Abstract The text deals with the questions of the size and character of the Slovenian Armed Forces (SAF). Ideas of downsizing the SAF's active component have been present for quite a while, and have additionally gained momentum due to the limited defence resources. The article looks at the size of Slovenian armed structures from a historic perspective in the light of the tasks set before the SAF by the Defence Act. The article also deals with the SAF's character and the source of its combat power - the infantry. Allied and other armies list several types of infantry, the fact which should be taken into consideration when deliberating on the type of infantry in the SAF. Of course, we are aware of the financial restrictions imposed on the SAF; therefore the conclusion includes some suggestions on how to achieve the proposed size and character of the SAF. The suggestions, however, are intended more as a base for a discussion and would have to be further analysed. 


\section{Key words Size of armed forces, Slovenian Armed Forces, NATO, infantry, active component, military strategic reserve.}

Introduction At the top of its power, the wartime strength of the Territorial Defence of the Republic of Slovenia (TD) comprised over 80,000 members. Such a number was never actually mobilised, but its capabilities still enabled this strength. After the War for Independence and later, when the conflicts on the territory of the former Yugoslavia ended, the size of the TD and later the Slovenian Armed Forces gradually changed. It ranged from a wartime strength of 54,000 members in 1994 through the maximum of 73,000 in 2001; 39,000 in 2002 and 2003, and 16,000 in 2004 (Grizold, 2005, pp. 125, 127) and the currently authorised 10,000. The SAF and the TD have throughout the process preserved the character of a light infantry force with a smaller manoeuvre structure and larger territorial structure ${ }^{1}$. For quite some time, there have been more or less formal ideas that the size and structure of the SAF should be reduced even further. In this respect, a number around 5,000 servicemembers is most often mentioned. Simultaneously, informal discussions have taken place both in the SAF and in the interested public concerning the nature of the SAF's character.

The size and character of the SAF are determined on the basis of missions entrusted to the SAF, the threats posed to the Republic of Slovenia, and its NATO membership. However, we must also consider the historical experience of the size and character of the armed forces of the Slovenian nation since the beginning of the $19^{\text {th }}$ century on. The SAF is and will remain largely a land force with infantry as its core branch and the centre of its combat power. Other branches and services provide infantry support or combat service support to a limited extent and can also function as independent units. Within the infantry as the SAF's central branch and source of its combat and non-combat power, a question arises what kind of infantry we actually need, since not every type of infantry is suitable for the missions and resources of the SAF.

\section{MISSIONS OF THE SLOVENIAN ARMED FORCES AND NATO}

Missions of the SAF as stated in the Defence Act (Article 37):

- Implement military education and training in armed combat and other forms of military defence.

- Ensure the necessary and required readiness.

- Organize military defence in the event of attack on the state.

- Participate in protection and rescue activities in the event of natural and other disasters in line with its organization and equipment.

\footnotetext{
In the 1990s, forces were divided into manoeuvre and territorial forces. In 2001, this division changed to include reaction forces, main striking forces and augmentation forces in order to finally become unified with the Alliance in 2004. Currently, the SAF forces are divided according to their role in the combat system and include combat forces, combat support forces, combat service support forces and command support forces, depending on their ability to deploy (deployable and non-deployable forces) and their level of readiness (high-readiness forces, low-readiness forces and long-term build-up forces) (Grizold, 2005, pp. 134, 135, 136).
} 
- Execute obligations assumed by the state in international organizations and through treaties.

The missions stated in the Defence Act are clear. The SAF must provide military defence in the event of an attack, participate in protection and rescue activities in the event of major emergencies and meet international obligations, which the armed forces can meet. It must therefore conduct training and provide adequate readiness. The mission of the SAF, however, is defined differently in various strategic documents.

The Resolution on General Long-Term Development and Equipping Programme of the Slovenian Armed Forces up to 2025 (ReSDPRO SV 2025) defines that the mission of the SAF is "to contribute to the implementation of interests and national security objectives of the Republic of Slovenia through military capabilities" (National Assembly of the RS, p. 10). As for the missions of the SAF, the ReSDPRO SV 2025 summarizes the missions set in the Defence Act.

The Defence Strategy of the Republic of Slovenia stipulates that the mission of the SAF is "to ensure military power of the Republic of Slovenia through military capabilities, which represents the most powerful and the outmost instrument of the state for promoting and implementing its national interests, and national security objectives" (Government of the RS, 2012, p. 9).

The 2006 Military Doctrine states that "the mission of the SAF is to deter military aggression against the Republic of Slovenia in cooperation with the Alliance and to contribute to international peace and stability within and outside the borders of the Alliance. In the event of military aggression, the SAF carries out, independently or in cooperation with its allies, the military defence of the Republic of Slovenia with the objective to resist and deter the enemy and to re-establish the national sovereignty on the entire territory of Slovenia." (Furlan, 2006, p. 24).

Based on the above, we can see that the mission of the SAF is not defined uniformly by all the strategic documents, which may have negative consequences. The mission as defined by the ReSDPRO SV 2025 and Defence Strategy refers to what is called the grand strategy ${ }^{2}$ of the state and discusses its role in relation to national security interests and objectives. The mission, summarized from the Military Doctrine, however, provides a more concrete definition of the SAF's modus operandi as it follows the defined objectives, and as such provides a better framework for the discussion about the size and character of the SAF.

On the basis of the strategic documents it can therefore be concluded that the defence strategy of the Republic of Slovenia is deterrent and that, in order to ensure its own security, it mainly relies on the Alliance. Doing this, it may quickly find itself trapped by the excessive devolution of the responsibility for its own safety on other members

2 The term is used by Barry Posen in his book and refers to national security strategies of different countries. 
of the Alliance. It should therefore be clearly understood what and how much security the Alliance provides. In this respect, it is crucial to know and understand articles 3 and 5 of the North Atlantic Treaty.

Article 5 of the Treaty reads: "The Parties agree that an armed attack against one or more of them in Europe or North America shall be considered an attack against them all and consequently they agree that, if such an armed attack occurs, each of them, in exercise of the right of individual or collective self-defence recognized by Article 51 of the Charter of the United Nations, will assist the Party or Parties so attacked by taking forthwith, individually and in concert with the other Parties, such action as it deems necessary including the use of armed force, to restore and maintain the security of the North Atlantic area. "3 Article 5 does talk about the fact that an attack against one member of the Alliance is an attack against them all, but at the same time, it allows each country to respond to this attack in its own way. Armed force is just one of the ways in which they can respond, which means that an attack against the Republic of Slovenia would not necessarily imply assistance of the Alliance such as one would expect. The Alliance does not have its own armed forces, but it includes forces that are contributed to joint commands by individual states. The Alliance makes us safer only in conjunction with the global threats that threaten both Slovenia as well as the majority of other allies, or at least the most powerful ones. In the event of a local threat, however, the reliance on the Alliance is tenuous.

Article 3 of the North Atlantic Treaty reads: "In order more effectively to achieve the objectives of this Treaty, the Parties, separately and jointly, by means of continuous and effective self-help and mutual aid, will maintain and develop their individual and collective capacity to resist armed attack." 4

Article 3 of the Treaty clearly imposes the requirement that each member state develop its own capabilities for defence against an armed attack. Therefore, we cannot agree with Grizold, who states that "the division of military capabilities into those for the needs of national defence and those that are available to NATO almost no longer exists." (Grizold, 2005, p. 187). Member states, including the Republic of Slovenia, must develop their own ability to defend themselves against an attack. ${ }^{5}$ If a member state does not meet the requirements of this Article, it cannot expect that other member states would fill in the shortcomings in its defence capabilities.

The Alliance has its price, and no member should allow itself to ignore its own defence capabilities and in doing so rely that the security will be provided by

\footnotetext{
(http://www.nato.int/cps/en/natolive/official_texts_17120.htm)

(http://www.nato.int/cps/en/natolive/ official texts_17120.htm)

At the recent wave of terrorist threats, the attack on French satirical newspaper, France and Belgium sent their soldiers to the streets to ensure safety independently of the Alliance. These capabilities can be the same capabilities that are available to the Alliance, but the fact is that the national-security needs are separate from the Alliance, as demonstrated in Afghanistan, where, despite the activation of Article 5, it took almost two years before the rest of the Alliance was actively involved in the conflict.
} 
Article 5 of the Treaty. The Alliance can be effective only if all the allies fulfil their commitments. The reality is of course different and shows that the politicians often put the responsibility for the security of their own countries into the hands of other Allies, thus neglecting their own capabilities. Membership can be extremely useful for shared capabilities and cost reduction in joint projects. If, therefore, the Republic of Slovenia gives up, for example, its armoured (tank) capabilities, air defence, military aviation and so on, it must have a clear plan on how it will compensate this shortage within the Alliance: whether it will invest in better anti-tank capabilities, a joint air-defence system, regional air forces etc. Slovenia has already found solutions within the Alliance to make up for the shortages of certain capabilities; however, all cannot be solved through the Alliance, certainly not with the defence expenditure of $1.1 \%$ of GDP, where only $0.74 \%$ of GDP is allocated for the needs of the SAF. The rest of it is intended for other capabilities in the defence system of the Republic of Slovenia, namely the Civil Protection Service, fire-fighters and others. (Lecture of Slovenian CHOD at http://youtu.be/tEHYGFWO7pQ, from 12.30 to 12.45).

Although allied countries share the risks, costs and benefits of the war, the provision of security within the Alliance also brings about great hazards. Countries within the alliances leave the responsibility for their own safety to others, which leads to unrealistic reduction of their own security resources. Another trap of the Alliance, on the other hand, is following a military doctrine of the leading nation, although it may not be appropriate for a small country (Posen, 1984, p. 73). We believe that NATO is an example of such an alliance with the United States that have a highly offensive military doctrine more or less openly leading all other allies into a similar doctrine. In this respect, the SAF is despite the fact that it is declaratively committed to a deterrent doctrine, structurally more similar to an army, which develops an offensive doctrine. ${ }^{6}$

Slovenian politics and the public must be clearly aware that the safety of our country is primarily our own responsibility and that extreme saving measures in defence capabilities will leave serious consequences.

\section{SECURITY THREATS AND CHALLENGES OF THE REPUBLIC OF SLOVENIA}

The society in the postmodern era faces a number of more or less credible threats. According to Moskos "for a long time yet, different revolutionary / terrorist movements will be the most likely threat to a country in the postmodern era." (Moskos in Bebler, 2005, p. 316). However, we cannot write off the threats to which the

\footnotetext{
6 Offensive doctrine at the strategic level should not be confused with offensive actions at the tactical level. Even the armed forces, which develop defensive or deterrent doctrine at the strategic level, can and even need to develop an offensive doctrine at the tactical level, to assume the initiative in combat and interfere with the enemy's decision-making cycle. This is advocated by the function of command and control on the basis of the mission statement, also known in the SAF doctrine, which I discussed in more detail in the Contemporary Military Challenges of June 2014-16, No.2
} 
country was exposed in the traditional and the modern eras. ${ }^{7}$ According to Dandeker, post-modern armed forces have an extremely wide range of defence-related tasks and roles and must therefore have an appropriate structure and reserve component to perform them all (Dandeker in Moskos, 2000, p. 45). In addition to other features, Moskos in relation to postmodern armed forces also highlights the change in the purpose of the military from winning a war to the tasks that are not military in the traditional sense of the word, and the involvement of the military in missions with international legitimacy (Moskos, 2000, p. 2).

It is not about which threat is more likely or more significant. In a world that is as interconnected and volatile as today's it is impossible to prioritize threats in the long run. Grizold notes that post-Cold War threats around the world have a few common elements (Grizold, 2005, pp. 22, 23):

1. Integration, interlacing and interaction between military and non-military threats to security

2. Turning of national security to international security, and vice versa. Security today has global dimensions in spatial and thematic terms. In this respect, the security of individual countries is increasingly becoming the domain of the global international system.

3. Coherence and accountability among operators ensuring safety, such as national, international and transnational organizations, non-governmental organizations, multinational corporations, pressure groups, etc. have increased significantly.

4. The instruments and mechanisms for ensuring security are more complex and are integrated into the system at the level of both the state and the international community.

It is necessary to have a system which is designed so that it can adequately respond to any threat and is financially sustainable.

Strategic defence and security documents of the Republic of Slovenia come to similar conclusions and do not prioritise threats. They establish that in the short and medium terms the likelihood of direct military threats to the Republic of Slovenia is little, but not to be excluded. At the same time, however, the asymmetric nature of threats and their hybrid forms require both a non-military response to military threats as well as a military response to non-military threats (Def. Strat. RS, 2012, p. 3). If we could draw a lesson from contemporary crises and conflicts, it would be that they are unpredictable. But most unpredictable is the direction of development, which they will take - will they retain a local character or will they develop a regional one or become even broader, ultimately global. International security system is simply too unpredictable and interests which will prevail cannot be identified in advance so that

\footnotetext{
Allegedly, traditional societies existed until the end of World War II. They were characterized by massive national armies. Modern societies, on the other hand, existed from the end of World War II until the end of the Cold War. They were distinguished by the armies with professional officer corps, reduced size and advanced education. Postmodern societies in the post-Cold War period have armies, where boundaries between civil and military spheres are blurred. (Moskos in Bebler, 2005, p. 313)
} 
one could reliably estimate the developments. This has been confirmed by the recent two events of crisis in Ukraine, which shook and continue to shake the entire Europe, as well as by the achievements of Islamic State (ISIL) forces in Iraq and Syria.

Grizold states that »in addition to conventional threats (e.g. war, arms race, nuclear proliferation, etc.) modern security threats include non-military threats, which are becoming increasingly topical, such as mass violations of fundamental human rights and freedoms, pollution and consequently global warming, hunger, infectious diseases, drug trafficking and human trafficking, sudden migrations and others. These security threats, along with international terrorism, weapons of mass destruction, and what is referred to as non-functional states that are not only endangering their own population, but are also destabilizing the entire region, have become essential sources of threats to modern security. Such complex security threats require equally complex solutions. "(Grizold, 2005, p. 24).

Defence and security system of the Republic of Slovenia and in particular the SAF must therefore strive to maximize the flexibility of its structure and the individuals who make it up. The SAF must be prepared both for military threats to the national territory, as well as for natural and other disasters, cyber threats and operations in crisis zones around the world. There is no organization, which would be capable of responding to all these threats at once, and the armed forces will not take on the leading role in all of the events. However, there are threats where more significant initiative is required. These include traditional military threats to the national territory and participation in international operations and missions. Nevertheless, the Slovenian Armed Forces will also be involved elsewhere; in some places mostly with personnel and technical means (protection and rescue activities), and in others with some specialized elements, such as cyber defence, or specialists (e.g. in counterterrorist activities).

The key feature here is flexibility, which must be built into the system and constitute a part of each individual in the system.

\section{SIZE OF THE SLOVENIAN ARMED FORCES}

The choice of military doctrine of each country within what is referred to as national grand strategy defines the character, size and structure of its armed forces. Posen distinguishes between offensive, defensive and deterrent military doctrines. Offensive doctrines aim to disarm an enemy - to destroy his armed forces. Defensive doctrines aim to deny an enemy the objective he seeks. Deterrent doctrines aim to punish an aggressor - to raise his costs (material, human and financial), without reducing one's own (Posen, 1984, p. 14).

Considering the strategic documents and the military doctrine in force, the military doctrine of the SAF is deterrent. According to the Military doctrine "the mission of the SAF is to deter military aggression..." (Furlan, 2006, p. 24) The SAF should 
therefore, by its nature, structure and scope serve above all to deter potential threats. Of course, the SAF and the military security of the Republic of Slovenia cannot be considered separately from the Alliance. The fact is that NATO membership has a deterrent effect at least for conventional aggressors. However, the Alliance still shows identity crisis (Grizold, 2005, pp. 92, 93), which occurred not only after the end of the Cold War, but was above all caused by changes in the perception of what the concept of security in the post-9/11 period really means. After the Wales summit, the Alliance has become more aware that it must decisively deal with new forms of threats ${ }^{8}$, and has committed to further enhance its capabilities to address those threats (Declaration, 2014, no. 64). Among its fundamental tasks, the Alliance lists deterrence and defence against the threat of aggression against any member state, but at the same time notes that large-scale conventional aggression against the Alliance is unlikely, but should not be written off over the longer term. (NATO AJP-01 (D), pp. 2-2 and 2-3). Doctrinal documents state that response operations to crises and transnational and hybrid adversaries are more probable. The Alliance's structure corresponds to this fact and so will its further transformation (Declaration, 2014, no. 64), and also its expectations toward all member states. In accordance with Posen's definitions of military doctrine, the doctrine of the Alliance is in my opinion offensive as it provides for short and rapid conflicts on foreign territories and places great emphasis on highly responsive and strategically deployable forces.

The SAF complies with the Alliance's guidelines with its current peacetime size and structure, but not with its military strategic reserve ${ }^{9}$. By no means, however, does this suffice for the deterrence of potential adversaries with its own armed forces so that the potential enemy would suffer so much loss for such a long period of time that it would no longer consider an armed aggression sensible. Even the Doctrine of Military Strategic Reserve of the Republic of Slovenia stipulates that "the possible benefits of the potential aggressor should be significantly lesser than the damage... we as a potential victim of the attack can inflict on him" (MOD 2012, p. 6). The Alliance is currently the only deterrent of the defence doctrine of the Republic of Slovenia and the SAF's current structure is not appropriate for a deterrent doctrine. For the Republic of Slovenia and the SAF, a deterrent doctrine is the only sensible one, as small countries with very limited resources do not have the conditions to develop an offensive or defensive doctrine. At the same time, the Republic of Slovenia has no other option but to ensure its security within the Alliance. Another option is neutrality, but for this adequate security assurances within the international community would have to be obtained, which is, in the long-term, unpredictable and anarchistic. Slovenia does not have realistic options for anything like this and the hazard it would be exposed to in this respect is unacceptable.

\footnotetext{
8 The Alliance refers to transnational and multi-dimensional threats, hybrid threats, terrorism and ballistic missile threat (Declaration, 2014, no. 13, no. 32, no. 55). What these threats have in common is that they do not target only military objectives, but rather political. Thus, hybrid threats comprise a mixture of explicit and implicit military, paramilitary and civilian threats, according to the current situation.

9 The concept of military strategic reserve is only formal, written on paper, and is not precisely elaborated nor tested, so it cannot and will not be realised.
} 
The current concept of the SAF's strategic reserve foresees to increase its volume to 25,000 members in one year (Doctrine of Military Strategic Reserve of RS, 2012, p. $10,24)$. I find this unrealistic, because the SAF no longer has any reserve except the contract reserve, which is not intended to increase the military strategic reserve, but to complement the SAF's active component. Regional Defence Administrations do keep a military service record, however the registered citizens do not receive notices on military training, nor is their competence for military service monitored. The SAF also has no plans on how to use these records and what to do in case of need. Considering the pace of modern warfare and the development of crisis situations, the SAF will not have one year to prepare for the potential threat. Furthermore, it is not clear how the politicians would make a radical decision such as the mobilization of military strategic reserve a year in advance, when there is no guarantee that a crisis or war would grow into a conflict of such proportions that it would threaten Slovenia. The SAF also lacks leaders who could train 25,000 members. Where would the personnel to train strategic reserve leaders come from? It should be noted that a large part of the SAF, in particular its most qualified part, has to perform operational tasks, which should certainly be many during a crisis (including the fulfilment of commitments to the Alliance). The second-class personnel, however, cannot train other than the third-class strategic reserve leaders. Additionally, any training under the conditions of military occupation would be extremely difficult, and, above all, slow.

Plans to increase the size of the SAF, which are only in the form of a concept, will not work. If we are seriously considering increasing the size of the SAF with the strategic reserve, we must have a system in place which will live and will be at least partially periodically tested.

The Slovenian Armed Forces currently includes 7,963 members, 7,049 of which constitute the active component, and the remaining 914 are members of the contract reserve. The figures apply to December 2015 (http:// www.slovenskavojska.si/oslovenski-vojski/). The total authorised size of the SAF includes 10,000 members, but the SAF cannot reach it because of human resource constraints imposed by the Government and due to the situation on the labour market and its own lack of competitiveness. The maximum acceptable number for active component thus amounts to 7,600 members and 1,500 members of the contract reserve, a total of 9,100 members.

The manoeuvre part of the SAF, i.e. the part which is intended to face the enemy on the battlefield and defeat it in an armed conflict, comprises four infantry regiments with 700 members according to non-official sources; therefore a total of about 2,800 members ${ }^{10}$. Other SAF members provide combat support, combat service support

\footnotetext{
10 On-line sources have been used, which make no reference to official sources and are therefore not separately mentioned. Unfortunately, all the official sources known to me, which are associated with the numerical size of the SAF are classified as confidential and, therefore, cannot be referred to here. For the purposes of the article, I assume that sources available online are at least roughly correct.
} 
and command and control (C2) as well as military education and training. In a 1956 interview, U.S. General George C. Marshall said that "it is a completely mistaken illusion that infantry is easy to train" (Bolger, 1999, p. 29). For an infantryman, close combat with an enemy is an extremely personal and stressful experience. The fewer such soldiers there are in a society, the better they have to be. Good infantry is specially selected, well trained, and above all capable of making quick decisions and good judgment in combat (Bolger, 1999, p. 31).

This should be the most important qualitative difference between conscript and professional infantry. Conscripts perform their duties because they have to, while professional soldiers in principle want to do it. Conscript armed forces closely follow the programme where the content is prescribed by the number of hours, while the professional armed forces have to follow the achievement of standards. Their training is and should be harder, more realistic and better.

One of the advantages of conscript armed forces is their number. However, the quality cannot always compensate for the size. Therefore, we wonder what this number is for the SAF.

According to the Doctrine of the Strategic Reserve of the Republic of Slovenia, at least from the times of Turkish invasions to Slovenia's independence, the selfdefence skill of people on Slovenian territory was repeatedly recognized as useful. A brief historical overview of Slovenian armed forces over the past 100 years shows the following:

1. General Maister's army in 1918, approximately 12,000 members (http://www. slovenskavojska.si/o-slovenski-vojski/zgodovina/).

2. Slovenian National Liberation Army and Partisan detachments in August 1944, about 21,700 members (http://www.slovenskavojska.si/o-slovenski-vojski/ zgodovina/), by the end of the war, the number grew to about 35,000 (Guštin in Bebler, 2005, pp. 59-95).

3. Slovenian Home Guard around 13,500 members (ibid).

4. Mobilized into the German Armed Forces, 1941-1945, around 50,000 people ${ }^{11}$.

5. Territorial Defence of the Republic of Slovenia, June 1991, approximately 35,000 members (http://www.slovenskavojska.si/o-slovenski-vojski/zgodovina/).

Here, it should be noted that the army of General Maister worked almost exclusively in the northern and north-eastern part of Slovenia, therefore on a little less than half of today's Slovenian territory.

\footnotetext{
${ }^{11}$ Information about how many people were mobilized into the German army varies widely depending on the source. Seničar in his thesis gives a number 28,000 in 1943 only for Styria, but indicates 150,000 as the final number, which includes all who had been mobilized into military and paramilitary formations of the occupying forces. My assessment is therefore approximate and relates only to those mobilized into the German army.
} 
Slovenian Home Guard ${ }^{12}$ was limited to what was referred to as the region of Ljubljana and the operating zone of the Adriatic Coast, so again to a little less than half of Slovenian territory. Only Slovenian National Liberation Army and Partisan detachments were active in practically the entire territory of Slovenia, while it should be understood in their case that they constituted a guerrilla army ${ }^{13}$. They were organized into two corps and one operational zone, but the size and combat power of the Partisan corps would more resemble an Allied infantry division. This can be seen by comparing the size and structure of the $7^{\text {th }}$ Corps of the Slovenian National Liberation Army and the U.S. $2^{\text {nd }}$ Infantry Division ${ }^{14}$. At the same time, it should be noted that both the Slovenian Home Guard and the Slovenian National Liberation Army recruited their members from the same human resource pool of the Slovenian nation between 1941 and 1945, which was in a very efficient and organised manner also used by the German army.

In 1991, the Territorial Defence with its territorial structure effectively covered the entire Slovenian territory and successfully denied the enemy with a manoeuvreoriented doctrine. However, it was not intended for manoeuvre warfare aimed at defending the territory. In June 1991, its final size was about 35,000 members, which included about 10,000 police officers.

From the historic perspective, we can therefore refer to the 35,000 members of armed formations as to a force which can effectively deny the enemy's forces on the territory as large as the Republic of Slovenia. Also, the ability to deny or disrupt is what makes a military doctrine of a country deterrent, as this denies the enemy the objective it seeks and raises its costs (material, human and financial) (Posen, 1984, p. 14). This confirms the assumption from the ReSDPRO SV 2025 (up to 10,000) and the Doctrine of Military Strategic Reserve (up to 25,000), which together make up an armed force with 35,000 members.

The ratio between the active component and the anticipated size of the wartime component or what is referred to as the strategic reserve is crucial. For illustrative purposes, we can look at the German Armed Forces, After the First World War, it was limited to 100,000 members, which did not meet the defence needs of Germany, should the war in Europe reoccur. For this purpose, German General Staff sought to increase its size as quickly as possible. Consequently, they created an army of leaders with the concept of mission command, where almost all members of the armed forces were expected to be able to assume commanding duties up to two levels higher than they actually performed them in the structure of 100,000 members. When conditions were suitable, this enabled them to grow rapidly without deteriorating the quality. As

\footnotetext{
${ }^{12}$ In this paper, we use the phrase Slovenian Home Guard as a generic name for the units, which collaborated with the occupier, because their names and organization during the years of war changed frequently.

${ }^{13}$ Brigades of the Slovenian National Liberation Army included units were intended for manoeuvre combat. The rest of the Slovenian National Liberation Army comprised what was referred to as district forces.

${ }_{14}$ Partisan companies included from 30 to 80 fighters; battalions 100 to 250, and brigades 300 to 800 fighters (Guštin in Bebler, 2005, pp. 59-95). Units of the Slovenian National Liberation Army could nevertheless be compared to a-level-lower allied units, but only numerically, certainly not regarding their firepower, which made the units of the Slovenian National Liberation Army even weaker.
} 
a result, by 1935, the number quickly increased at first from 100,000 to 300,000 and then to $1,000,000$ in 1938 . The problem was that the industry was not able to keep pace and that the political leadership required even faster growth, namely 4,000,000 by 1939. This eventually led to deterioration in the quality of the armed forces (Craig, 1964). The historical experience shows that rapid increase in the armed forces is possible, but requires the fulfilment of certain conditions, such as a built-in surplus of qualified leaders, ready-to-use infrastructure and guaranteed material base. On the other hand, however, even if all conditions are met, rapid growth has its limitations, which would particularly be evident if the growth was larger than triple.

If the SAF would have to establish a wartime size of around 35,000 members, which is evident from the historical experience and strategic documents, its active component should not be smaller than 10,000 members, while all the aforementioned conditions would have to be met. The most important in all this, however, is that it has a sufficient number of skilled leaders to assume duties within the military strategic reserve.

\section{CHARACTER OF THE SLOVENIAN ARMED FORCES}

With the latest transformation, the Slovenian Armed Forces obtained a new structure, which shows that this is mainly an infantry organization. The combat power of the SAF is based on four infantry regiments, which within the brigades include several combat "multipliers"15. With their help, each of the infantry brigades is, at least in theory, capable of forming a battalion battle group for the needs of the Alliance. Whatever the current or future structure of the SAF, the fact is that its combat power is based on infantry units of a battalion- or brigade-level. The question, however, is what type of infantry these units should have.

In the Alliance, there are several different types of infantry ranging from mechanized, motorized, naval, airborne, airmobile to mountain infantry. However, the concept of light infantry is not included in allied doctrines. Nevertheless, certain member states have other specialized types of infantry, such as U.S. Army Rangers, which can be regarded as light infantry.

If we acknowledge the infantry as the cornerstone of the SAF's combat power, we must also ask ourselves what type of infantry would meet the defence needs of the Republic of Slovenia. In the past, various ideas have occurred ranging from airborne infantry to airmobile infantry and ranger battalions. These ideas were interesting and very attractive to many people, but I believe that we should first ask ourselves what is the purpose of each specific type of infantry, what are its strengths and weaknesses, and how the SAF intends to fight its enemy ${ }^{16}$.

\footnotetext{
${ }^{15}$ These include combat support units, which are in theory indeed intended for regiments, but it is solely in their commander's domain what, if anything, the regiments would get.

${ }^{16}$ In my opinion, I have already shown in the article that the normative military doctrine of the Republic of Slovenia is deterrent and that it is the only one possible for a country such as Slovenia.
} 
The SAF's tasks are very broad, ranging from the protection and rescue missions to the defence against external aggressors. There is no type of infantry, which would ideally correspond to all these tasks; therefore, I believe that we must derive from the most demanding task, which is the implementation of military defence, and then determine how to use this infantry for other tasks.

Airborne infantry has a very specific role to strategically project military force ${ }^{17}$ over distances which are beyond the reach of conventional means of transport (cf. Granada). As such, it is at its best, when it jumps directly onto the enemy. Its greatest advantage is the element of surprise. Once it copes with the enemy on the objective, it becomes very vulnerable (cf. Arnhem during World War II). It lacks mobility (except strategic), and, what is more, the maintaining of adequate readiness of these units is very expensive.

Airmobile infantry is the most mobile of all types of infantry (CC\&CS, 2011, p. A-104). Just like airborne infantry, airmobile infantry also requires specialized training, because it is not only about boarding any infantry unit on the helicopter and dropping it on a target. Its strength lies in the cooperation of the infantry with the aviation, but this can also be its greatest vulnerability. Helicopters are not armoured vehicles and it does not take much to shoot them down. ${ }^{18}$ The fall of the helicopter is usually fatal for both crew and the passengers. Airmobile infantry is thus strong only when and if infantry, artillery and aviation (combat rotary-wing and fixed-wing aircraft) cooperate. Helicopters, in particular combat ones, are rather costly, not only their purchase, but also the maintenance of their capabilities.

Mechanized infantry enables the progression of tanks, where this is not possible due to the terrain or the enemy. Mechanized infantry is disembarked only if necessary; otherwise the tactical tasks are performed with the infantry fighting vehicles which supress the enemy's infantry and enable the manoeuvre of tanks. Therefore, it is presumed that the mechanized infantry in the Alliance is equipped with vehicles carrying at least 20 -millimeter guns ${ }^{19}$. Only these weapons are capable of fighting together with a tank gun. From that, it can be established that the mechanized infantry is sensible, if there are tank capabilities present as well. The advantages of the mechanized infantry can only be fully exploited in joint warfare where tanks play the leading role. In this respect, it should not be forgotten that disembarkation elements of the mechanized infantry are usually very small, smaller than the light, airborne or airmobile infantry and can therefore burn out quickly. Armoured units are most efficient and fastest during manoeuvre, but they can only fight as part of a unit within the combined arms fight. Consequently, whoever builds mechanized infantry must also build all other elements - appropriate armoured units, the supporting artillery,

\footnotetext{
${ }^{17}$ CC \& CS, 2011, p. A-104, no. 1.1.

18 Its main limitation is own force protection (CC\& CS, 2011, p. A-104, no. 2.9).

${ }_{19}$ NATO Bi-SC Agreed Codes Capability and Capability Statements from 2011 does not define the explicit request for at least a 20-mm gun in mechanized infantry, but this fact arises from the requirement that mechanized infantry is "cable of providing support for armoured units" (p. A-103, paragraph 2.10). Other relevant sources of the Alliance are classified as confidential and, as such, cannot be used in this paper.
} 
and air support. Mechanized infantry is also capable of fighting independently without tanks, and can be very effective, but this is not its main purpose. All in all, tanks as infantry combat vehicles are also rather costly, not only their purchase, but also their maintenance.

Motorized infantry: its main feature is flexibility (Bolger, 1999, p. 259). It performs superbly in difficult terrain (mountains, forests, wetlands, urban areas), at night and in poor weather conditions. Its main disadvantage is that during the movement or manoeuvre it depends on the feet or motorized means of transport ${ }^{20}$. It has no armoured protection, except if it is equipped with armoured carriers. It should, however, be understood that armoured carriers are nothing but transport vehicles. Motorized infantry fights without combat vehicles with limitations in firepower, mobility and protection (CC \& CS, 2011, p. A-103). The burden of such warfare on the soldiers is enormous in both physical and psychological terms.

Naval infantry: Similarly to airborne infantry, its purpose is to provide for the strategic projection of force. Since it depends on sealift, it is much slower, but has much more firepower and longer self-sufficiency (15 days on land, and 6 months at sea in the region- these are the data for the U.S. Marine Corps). In addition, naval infantry has its own naval and air support (CC \& CS, 2011, p. A-91, A-92).

Mountain infantry: The infantry, whose competence and equipment are specifically adapted for operations in mountainous and Arctic terrains (CC \& CS, 2011, p. A-103, A-104). Compared to the motorized infantry mountain infantry's movement relies more on the rotary-wing than motorised capabilities. In addition to the warfare as such, mountain and arctic warfare also involves great physical strain; therefore appropriate selection for mountain infantry is of utmost importance.

Ranger infantry: It forms a part of the U.S. Army, but this type of highly trained infantry can also be found in other armed forces. Rangers are infantry. They are very well trained, led and equipped, however still only infantry. In the U.S. Armed Forces, ranger battalions are specialized to occupy airports and there is no one who could do this better than them. Within the U.S. Special Operation Task Forces, with whom they mostly collaborate, they have two primary functions: to provide a quick reaction force (QRF) and to raid (Bolger, 1999, p. 191). The Rangers, until very recently, fielded no scouts or mortars at battalion level, because these capabilities relate to sustained combat operations, not lightning direct action strikes. ${ }^{21}$ Rangers are elite infantry units which expect the best from their men and accordingly have an appropriate selection system. Standards of basic skills are excellent and they have the appropriate conditions for this - enough ammunition for training and enough time (no burden of guard and garrison duties).

\footnotetext{
${ }^{20}$ These can include trucks, armoured carriers $(4 \times 4,6 \times 6,8 \times 8)$, or in the extreme case any other vehicle.

${ }^{21}$ Nowdays, due to the experiences with sustained combat in Afganistan and Iraq, Ranger regiments do have mortars and scouts in their structure.
} 
Regardless of its type, modern, professional and small infantry must possess three core competencies: physical fitness, marksmanship and small-unit tactics (Bolger, 1999, p. 234).

At a declarative level, Military Doctrine of the SAF is deterrent. As we have already noted in the introduction, the SAF is a land force with infantry as the central element of its combat power. What infantry then corresponds to this doctrine? Airborne and naval infantries can immediately be excluded, since their main purposes are strategic force projection and offensive doctrine. Nevertheless, this is not the reason why certain SAF capabilities should not possess these competencies. This refers mainly to special operations forces, which due to the nature of their work certainly require airborne capabilities. In addition, various naval infantry formations would indeed merit consideration in terms of good practices in size, weapons and firepower.

Ranger infantry can also be excluded, as it is highly specialized and not intended for lengthy combat operations, envisaged by the deterrence doctrine. However, it would be well worth examining their selection procedures in terms of raising the "esprit de corps".

Airmobile infantry is very mobile, but it is also very expensive. Combat and transport helicopters are complex and very expensive weapons systems, but there is no true airmobile infantry without them. In addition, these systems are highly offensive and are designed for deep penetration or jumping over the opponent rather than for the exercise of control over the territory.

The Slovenian Armed Forces is gradually withdrawing tank capabilities from operational use. It only intends to keep the capability of one tank company $(+)$, while other tanks and infantry combat vehicles will be moved to the strategic reserve pool (Medium-Term Defence Programme, 2012, p. 39). It is therefore hard to understand the argument that the SAF needs a mechanized battalion battle group for its own development. Without the tank capability, the capability of mechanized infantry in the SAF does not seem sensible, except in the light of the fulfilment of commitments to the Alliance. The Alliance has tank capabilities and needs mechanized capabilities to support them. The SAF can therefore develop a mechanized capability in order to achieve greater interoperability within the Alliance, but I think this could also be achieved in other, less financially burdensome ways -the capabilities of motorized infantry must also be interoperable within the Alliance through information technology, procedures, weapon capabilities and C2 system. The biggest problem of any coalition operation is always the issue of C2 (Posen, 1984, p. 81).

At first glance, mountain infantry seems ideal for the needs of the Republic of Slovenia and the SAF. However, the fact is that mountains cover only a bit less than a quarter of Slovenian territory. The rest are the highlands, hills and plains. Additionally, the SAF has clearly expressed its ambitions by having founded a 
NATO Mountain Warfare Centre of Excellence. Nevertheless, mountain infantry is not flexible enough to form the basis of the SAF's combat power.

Finally, there is the motorized infantry. Its main feature is flexibility. At first glance, it would seem that the motorized infantry is also the most reasonably priced one. Perhaps it really costs less than most of other types of infantry, but it is far from being inexpensive. Motorised vehicles, be they trucks or armoured carriers, are not inexpensive systems. In addition, motorized infantry has to in some way compensate for its limited mobility, firepower and protection. It therefore needs more anti-tank weapons, more light mortars and other supporting weapons, and it must also be interoperable with allied C2 systems. Nevertheless, motorized infantry is, due to its numerosity and means of transport, still the most suitable one to participate in the protection-and-rescue system, which was also evident during recent major natural disasters in the Republic of Slovenia, glaze ice damage and floods.

Conclusion A brief historical overview and strategic documents suggest that the SAF should be able to increase its size to around 35,000 members. At the same time, the proposed maximum size of the SAF, the deterrent military doctrine, a wide range of statutory duties and limited financial resources suggest that the core of the SAF's combat power should be comprised of motorized and light infantry.

Of course, it would be unreasonable to maintain the active component of 35,000 personnel, but the SAF must have the system ready to upgrade it to such size without any major effort. The Doctrine of Military Strategic Reserve of the Republic of Slovenia provides only for system bases without prepared plans, and few generally voluntarily trained personnel. At the same time, it gives the SAF one year to increase its volume by up to 25,000 members. Meanwhile, there are demands issued to additionally reduce the current size of the SAF. In our opinion, these demands cannot withstand sound professional judgment unless the SAF's legally defined tasks are changed in the sense of conscious renouncement of an effective armed resistance in the event of threats to national sovereignty. At the same time, we believe that the conceptual solutions provided by the Doctrine of Military Strategic Reserve will not sustain serious examination. Neither the SAF nor the rest of the defence system of the Republic of Slovenia in their current state is able to establish a system within one year that would ultimately result in 35,000 personnel trained for combat and positioned within appropriate formations. It is also impossible to expect that the SAF in its current financial and political situation would in any way increase its peacetime size.

Accordingly, solutions should be found somewhere in-between. The SAF should have pre-prepared plans for the use of the military strategic reserve as well as the formation of its units. ${ }^{22}$ This would enable the SAF and the rest of the defence system to arrange material and human resource planning. The SAF would practically have

\footnotetext{
${ }^{22}$ According to the Defence Act, this would be the war formation of the SAF.
} 
no expenses in this respect, except for working hours of staff officers and MoD officials who have to prepare these plans and formations. ${ }^{23}$

In this context, it is also necessary to think about the structure and purpose of the contract reserve. The contract reserve could provide a part of the most important commanding personnel for the military strategic reserve.

Major importance lies on the military education system, which should enable a threefold increase in the SAF's peacetime structure. This does not refer to its size, but the fact that education and training should prepare the commanding personnel of the peacetime structure to assume senior duties within the military strategic reserve. ${ }^{24}$

Consideration should also be given on how to provide an appropriate number of trained individuals for the military strategic reserve. Growth from 10,000 to 35,000 without a clearly defined pre-prepared and tested plans and formations is unrealistic. It is unrealistic that it be achieved in 365 days, if there were ever so many people available, but considering the pace of the development of modern crises, I strongly doubt it. It is clear that relying on those who have volunteered to do military service will not be enough. It would be easiest, of course, to reintroduce some form of civic obligation, which would provide citizens with the basic military knowledge needed to quickly establish the military strategic reserve, maybe in a shorter form than we used to know (up to 3 months), and which would be supplemented by the protectionand-rescue topics ${ }^{25}$. However, since this is rather unlikely, we should consider other options, such as the introduction of defence and military topics into the mandatory programme of secondary schools, perhaps even faculties.

At the same time, the SAF must retain at least the current peacetime size of up to 10,000 members, authorised with the ReSDPRO SV 2025. Any reduction below this number will impede the realisation of the idea of the military strategic reserve's growth to up to 25,000 members. This will simply be physically impossible to achieve within the available time frame. Additionally, recruitment measures will have to be taken to fill the posts in the active component, which will necessarily lead to adverse financial consequences. Security costs money and, despite the slogan that more can be done with less, there are simply limits, beyond which less is merely less.

\footnotetext{
${ }^{23}$ The military strategic reserve should exist as a war formation, without status and financial benefits of peacetime formations. It should not be possible to man it beforehand with members of the active component, at least not until decision is made to activate the military strategic reserve. Plans for the manning of war formations with members of the active component should be pre-prepared. If not, the concept will degenerate, as has happened before and the strategic military reserve would be used to solve career problems of individuals. This would be counterproductive.

${ }^{24}$ Platoon commanders should have the skills to lead the military strategic reserve company and activities in its most important staff duties. Company commanders should be able to lead military strategic reserve battalions, regiments, etc.

${ }^{25}$ This form of conscription would not produce useful combat units. However, it would provide individuals trained to use weapons and with basic tactical skills at squad level, perhaps even platoon level. Additionally, it would allow citizens to be more actively involved in protection and rescue activities.
} 
The core of the SAF's peacetime combat power structure should therefore consist of motorized infantry, while the core of the war combat power structure $(35,000$ personnel $)$ would be a combination of motorized and light infantry (motorized infantry to perform manoeuvre warfare activities ${ }^{26}$, and light infantry to cover the territory ${ }^{27}$ ).

Motorized infantry is flexible enough to be able to fulfil all the tasks set by the law and be at the same time financially sustainable. Slovenia's contribution to the Alliance is always a matter of negotiation and should primarily reflect its deterrent military doctrine. The fulfilment of commitments to the Alliance is important and affects the credibility of the country in the international environment. Slovenia must also make a contribution proportionate to the overall security provided by the Alliance. Too often, only negative aspects of NATO membership appear in the public, while we keep forgetting that, for example, the Republic of Slovenia uses the Alliance's instruments to protect its airspace, to use the type of training and firing ranges Slovenia does not have, and so on, all without significant costs.

Modern motorized infantry is not an inexpensive system. Maybe someone might have in mind a poorly equipped and trained military force, but this could not be further from the truth. Modern motorized infantry is well-equipped and well-trained military force which does, however, have its limitations when it comes to mobility, firepower and protection, but also has the systems, training and commanding personnel, which can neutralise these deficiencies. The biggest advantage of the motorized, but also light infantry is its flexibility.

Fiscal reality is fierce and with the anticipated trends in resources for the needs of the SAF, we have to ask ourselves how to proceed. Insisting on figures, which the finances do not permit, can only be counterproductive. The minimum, below which the SAF should not go, is the pursuit of capability goals agreed with the Alliance. Maybe some of the capability goals could also be changed through the Alliance's defence planning process. The fulfilment of capability goals along with the fulfilment of its commitments to the Alliance also brings the retention of minimum expertise and at least the skeleton of the SAF's structure. However, it does not enable the performance of statutory tasks of the SAF and even severely limits its activities in the protection and rescue system. Capability goals represent approximately $4,100^{28}$ members of the active component, but even these cannot exist on their own. Even they need external combat service support elements (maintenance, supply, transportation, etc.), infrastructure, education

\footnotetext{
${ }^{26}$ Deployable and non-deployable forces of high and low levels of readiness. Their generation must be enabled by the peacetime formation. The active component generates deployable forces for operations within the Alliance (battalion battle groups and other NATO capability goals for the SAF), while the combination of active component and contract reserve enables the generation of forces for operations at home (two brigade battle groups).

${ }^{27}$ Non-deployable long-term build up forces according to the SAF Military Doctrine. These forces would represent the military strategic reserve.

${ }^{28}$ On-line sources have been used, which make no reference to official sources and are therefore not separately mentioned. Unfortunately, all the official sources known to me, which are associated with the numerical size of the SAF are classified as confidential and, therefore, cannot be referred to here. For the purposes of the article, I assume that sources available online are at least roughly correct.
} 
and training and C2 (also C2 with the Alliance). After we add what is necessary for the establishment of the capability goals, we would probably come up with about 6,500 members of the active component. But this can only be a temporary solution that bridges the poor financial situation and in fact probably does not bring much financial benefits, as well as it causes damage to national security. However, it would allow for the transfer of a part of financial resources from the personnel remuneration account to the account for modernization and thus start the development of capability goals.

At the same time it is also important to recognize what are the recommendations of the Alliance related to the deployability, high readiness and sustainability. According to the recommendation of the Alliance, armed forces are to have 50 per cent of deployable forces, 10 per cent of high-readiness forces at home and 0.8 per cent of sustainable forces. Given the fact that capabilities comprised in the capability goals are all deployable forces, the size of the SAF should, in view of the recommendations of the Alliance, not be smaller than about 8,200 members.

The SAF should in any case have pre-prepared plans and formations for the structure of 10,000 members of the active component, as well as political guarantees for the growth and manning of formations as soon as the fiscal position allows it.

Along with this, clear priorities should be established regarding the manning of units which follow the capability goals and fulfil the commitments to the Alliance. The remainder of the active component is first dedicated to the establishment of two manoeuvre brigades of light infantry with all the necessary combat multipliers, and then to the establishment of the military strategic reserve should it be activated.

The SAF must therefore take a firm and reasoned position against any attempt of reducing its current size, while at the same time actively promote public debate on its purpose, size, character and structure. For the purposes of this discussion, it must also achieve internal unity and prepare professionally substantiated arguments, which it will defend. The end result may still turn out negative for the SAF and in this case, we, SAF members will have to accept such final decisions and take the maximum out of them. Nevertheless, we must not allow any decision on the reduction the size of the SAF to be taken before the arguments of the SAF are clearly heard and acknowledged.

2. Bolger, D. P., 1999. Death Ground - Today's American Infantry in Battle. Random House Publishing Group.

3. Craig, G. A., 1964. The Politics of the Prussian Army 1640-1945. London: Oxford University Press.

4. Declaration Issued by the Heads of State and Government participating in the meeting of the North Atlantic Council in Wales, Press Release (2014) 120, Issued on 05 Sep. 2014 Last updated: 16 September 2014.

5. Furlan, B. (et al), 2006. Military Doctrine. Ljubljana: Defensor d.o.o.

6. Government of the RS, 2004. Zakon o obrambi (uradno prečiščeno besedilo). Ljubljana: ULRS. 
7. Government of the RS, 2013. Srednjeročni obrambni program Republike Slovenije 20132018. Ljubljana: št. 80300-1/2013/3 of 1 February 2013.

8. Grizold, A., 2005. Slovenija v spremenjenem varnostnem okolju, k razvoju obrambno zaščitnega sistema: Izzivi in spodbude. Ljubljana, FDV.

9. Kuster, J., 1979. Spominski zbornik ob 60-letnici bojev za severno slovensko mejo 19181919. Maribor: ZGEP Pomurski tisk.

10. Lecture of Slovenian CHOD at http://youtu.be/tEHYGFWO7pQ, 13 January 2015.

11. MO RS, 2009. Strateški pregled obrambnega resorja 2009. Ljubljana: MO RS.

12. MO RS, 2012. Doktrina vojaške strateške rezerve RS. Ljubljana: MO RS.

13. Moskos, C. C., 2000. The Postmodern Military. New York: Oxford University Press.

14. National Assembly of the RS, 2010. Resolution on General Long-Term Development and Equipping Programme of the Slovenian Armed Forces up to 2025 (ReSDPRO SV 2025). Ljubljana: $M O R S$.

15. National Assembly of the RS, 2010. Resolution on National Security Strategy of the Republic of Slovenia (ReSVN-1). Ljubljana: MO RS.

16. NATO, 2010. AJP-01(D) Alied Joint Doctrine. NATO Stardandisation Agency.

17. NATO, 2011. Bi-Sc Agreed Capability Codes and Capability Statements. Belgium: Supreme Allied Commander, Europe.

18. O Slovenski vojski, http://www.slovenskavojska.si/o-slovenski-vojski/zgodovina, 13 January 2015.

19. Posen, B. R., 1984. The Sources of Military Doctrine - France, Britain, and Germany Between the World Wars. Beograd 1992: Vojnoizdavački i Novinski centar.

20. Seničar, M., 2006. Slovenski fantje v vojski tretjega rajha-diplomsko delo. Ljubljana: $F D V$.

21. Severnoatlantska pogodba at http://nato.gov.si/slo/dokumenti/severnoatlantska-pogodba, 13 January 2015.

22. The North Atlantic Treaty at http://www.nato.int/nato_static/assets/pdf/stock publications/20120822_nato_treaty_en_light_2009.pdf, 13 January 2015.

23. The Wales Declaration on the Transatlantic Bond, Press Release (2014) 122, Issued on 05 Sep. 2014, 10 September 2014.

24. Vlada RS, 2012. Obrambna strategija Republike Slovenije. Ljubljana: št. 80000-1/2012/4, 7 December 2012. 


\title{
ALI LAHKO PROCES PROFESIONALNEGA VOJAŠKEGA IZOBRAŽEVANJA USTVARI VOJAŠKE STRATEGE?
}

\author{
CAN THE PROCESS OF PROFESSIONAL MILITARY \\ EDUCATION CREATE MILITARY STRATEGISTS?
}

Povzetek Izobraževanje vojaških strategov je tema, ki v pogojih vedno bolj kompleksnega varnostnega okolja postaja ponovno aktualna. Vojske bolj kot kdaj koli prej potrebujejo voditelje, ki bodo sposobni strateškega razmišljanja. Novembra 2011 je na Poveljstvu za doktrino, razvoj, izobraževanje in usposabljanje potekalo 5. redno srečanje Foruma centralnih evropskih držav o vojaškem izobraževanju (Central European Forum on Military Education - CEFME). Osrednja tema posveta je bilo izobraževanje vojaških strategov. Na srečanju so sodelovali visoki predstavniki s področja vojaškega izobraževanja iz devetih srednjeevropskih držav in predstavnik zveze Nato. Osrednja referata sta pripravila Uroš Krek, predavatelj predmeta vojaška strategija $\mathrm{v}$ generalštabnem programu Slovenske vojske, in polkovnica Mojca Pešec. V nadaljevanju avtorja predstavljata poglede na programe izobraževanja vojaških strategov v Sloveniji s teoretičnega in praktičnega vidika in utemeljujeta potrebo po intenzivnejšem in kakovostnejšem študiju strateške teorije za učitelje in študente predmeta vojaška strategija, nujnost oblikovanja celovitega programa učenja strategije $\mathrm{z}$ vidika izbora udeležencev in predavateljev ter potrebo po postavljanju dosegljivih ciljev, ko gre za časovni obseg in določanje vsebin programa. Oblikovanje nove generacije kompetentnih častnikov, ki bodo sposobni prepoznati varnostne izzive 21 . stoletja in strokovno prispevati k civilnovojaškemu procesu oblikovanja strategij, je nujno.

\section{Ključne Strategija, vojaški strateg, vojaško izobraževanje in usposabljanje.}

besede

Abstract In the increasingly complex security environment the education of military strategists is a topic which is again becoming of interest. More than ever before, the armed forces need leaders who will be capable of strategic thinking. In November 2011, the 5th regular meeting of the Central European Forum on Military 
Education (CEFME) was convened at the Doctrine, Development, Education and Training Command. The central theme of the conference was the training of military strategist. The meeting brought together senior military education representatives from nine Central European countries, and a representative of NATO. The two central papers were prepared by Uroš Krek, military strategy lecturer in the Slovenian Armed Forces General Staff Programme, and by Colonel Mojca Pešec. In their article, the authors present views on education programmes for military strategists in Slovenia from the theoretical and practical point of view, and substantiate the need for more intensive and better quality strategic theory study programmes for military strategy teachers and students. They also define the need for developing a comprehensive programme of learning the strategy in terms of selection of participants and lecturers, and the need for setting up achievable targets when it comes to the time frame and the determination of programme subjects. It is essential to form a new generation of competent officers who will be able to identify the 21 st century security challenges and contribute expertly to the civil-military process of the strategies formulation.

\section{Key words Strategy, military strategist, military education and training.}

Introduction In the recent decade, countries have faced increasing threats to global security. In comparison to the threats from the previous periods, these threats are more intense, more complex, multidimensional and above all unpredictable. As the importance of classic military threats to security is diminishing, non-military threats are becoming increasingly more common. Despite the continued efforts of the global community to establish peace and security, threat management is becoming increasingly challenging. States and international institutions, such as NATO, strive to establish systemic solutions and appropriate mechanisms for the provision of a comprehensive approach to the resolution of contemporary crises though the interconnection of (competent) institutions. To be able to better manage possible crisis situations, the crisis management systems defining coordination, interagency cooperation and mobilization of social resources and like are being established in individual countries and across the international community.

But what should the military or civilian experts and leaders who will be capable of directing and managing such complex systems be like? What knowledge and what kind of skills should they have to be able to effectively incorporate the expert findings of the highly specialized government and non-government agencies into the appropriate anti-crisis measures?

Essential for the coping with the current and the future security hazards and threats is to have the right people in the right positions at the right time. Each state should form and establish an identification, selection, education and training system for leader candidates capable of strategic management and of making decisions regarding national security. Leadership signifies the coping with challenges and the capacity to motivate, unify and direct people towards a specific objective. A 
state desiring to establish an effective government strategy for the elimination of security threats must have capable leaders at all management levels; leaders who successfully manage and guide comprehensive systems and organizations with their knowledge, skills and personal qualities.

\section{CAN A GOOD MILITARY STRATEGIST BE THE RESULT OF APPROPRIATE EDUCATION?}

The "strategy" notion covers not only the capability of planning, but also the capability to be goal-oriented and to be able to predict effective actions for the attainment of political and military objectives. Strategy introduces a special way of thinking and conduct, the ability to see the bigger picture and understand the connection between and interdependence of activities and their consequences. The nature of strategy is universal and not linked to a specific place or time. Strategy students should therefore be taught to think strategically outside the familiar constraints. Strategy teachers are not creating experts for solving strategic issues from the early 21 st century, but experts who will be capable of strategic thinking and strategic assessment of all time-space situations.

Strategists must be capable of long-term and comprehensive planning, decisionmaking, command and control which to a great extend depends on the character and personal characteristics of an individual (Troha, 2009, p. 77). They must also understand theory and be capable of upgrading their theoretical knowledge with experience. For this reason, there are certain limitations regarding the teaching of strategy within the formal educational process; those who excel in the understanding of military theoreticians are not necessarily the best of strategists.

There is but a handful of strategy genius, but there are individuals with a talent for strategy both in the military and in the business world. Just as any other talent, the talent for strategy can likewise be improved through education and operation in appropriate circumstances. The integration of personal characteristics and values with knowledge and skills during the education and training process supplements and develops individuals' capability (Troha, 2009, p. 74).

All professional military education systems believe to be educating military strategists and leaders. However, the curricula of higher military education programmes are often not oriented towards the development and promotion of strategic and critical thinking. They are more influenced by the characteristics and expectations of the training participants who have entered this program because they have performed duties which enabled them promotion and further education. Participants of strategic education are not selected on the basis of scientific procedures or methods aimed at assessing their psycho-physical characteristics, but by their superiors (Kotnik, 2008, p. 88-89). They are usually selected for their past success and diligence in the performance of their duties and are not required to have predispositions for a strategist or meet the objective criteria for academic 
studies (Baraka et al. 2010; Allen, 2010). On the other hand, there are some capable individuals who are not sent to schooling by military units as it is believed that sending them to schooling would mean depriving them of first-hand experience in practice. We, however, know that tactical experience without the possibility of insight into and understanding of the entire spectrum of complex situations does not support the development of strategists (Allen, 2010; Bethel et al., 2010).

Experts participating in military education estimate that the graduates of the current university programmes do not meet the standards required for the production of coherent and logical arguments and for written expression. (Gray, 2009). Clear expression and argumentation is a prerequisite for entry into the professional military education system. Should the students lack this skill, its development has to be included in the curriculum which represents a considerable challenge for the planners of military education. Education in the military education system is sadly still more of a »necessary evil« required for career path development, and to a much lesser extent an honour and an privilege bestowed only upon a couple of chosen individuals expected to fulfil their study obligations with a high level of academic maturity. ${ }^{1}$

Military leaders of the 21st century have to learn strategy. The strategy studies are compulsory at the master and doctoral levels. Study candidates should thus be selected based on the assessment of their capability to effectively and logically integrate different information into coherent conclusions which can be applied in problem solving. Personal experiences are undoubtedly the best teacher. However, knowledge and wisdom deriving from the works of the greatest strategic minds are equally important and valuable.

The learning of strategy cannot be founded exclusively on contemporary challenges and challenges anticipated in the near future. By employing this approach, strategic studies would become nothing more but an examination of the current situation. The students would thus learn to value only those strategic issues that they estimate as extremely important, which would taint their analysis with prejudice. A good strategist is highly educated also in other areas, has vast general knowledge and is familiar with the development principles of the society in which he is active. The success of strategic operation often depends on the strategist's capability to successfully communicate military issues to professional politicians (Kotnik, 2008).

\footnotetext{
A research conducted among education providers, participants and graduates of all levels of military education programmes in the SAF in the field of military education and training in the context of the Defence Sector Strategic Review (SPOR 09) confirmed these statements. The findings of the research are available in the joint material of the inspection performed at the Ministry of Defence of the Republic of Slovenia.
} 


\section{THEORETICAL ASPECT OF THE IMPORTANCE OF EDUCATION OF MILITARY STRATEGISTS}

"The illiterate of the 21 st century will not be those who cannot read or write, but those who cannot learn, unlearn and relearn."

\section{Alvin Toffler}

Strategy education is important for the development of the strategic approach, a way of thinking that can help solve contemporary and future strategic challenges. Nonetheless, such education should be based on very clear assumptions regarding the nature, importance and function as well as the fact that the nature of strategy is constantly changing.

Theoreticians (Gray, Hughes, Lyman, McCausland) agree that a good strategist is a result of the nature and personality, in short, psychological characteristics, and the experience related to the opportunities presented to an individual during his personal and professional development. They all promote the importance of formal education; although there is no scientific proof that education and training do in fact contribute to the making of a strategist.

Colin Gray is convinced that strategic talent nowadays suffices for work at the strategic level. A strategic genius, however, is a true rarity and not even close to continuous phenomena, as they are hard to be found. Both the conceptual basis which will serve as a foundation for the study of strategy and the desired content of strategic education have to be defined. He also warns that different circumstances require different strategic conduct which should be taken into account during the preparation of the curriculum for strategic education (Gray, 2009).

The education of military strategists should include both theory and the practice. It should include ideas and the method of their execution through plans carried out by commanders.

Wayne P. Hughes recommends that the strategy and tactics are taught in a way that the contents supplement and upgrade each other, stressing that it is the tactics that defines the borders of strategy. Theory (strategy as a plan) and practice (tactical activity) constitute a whole. The difference lies in the purpose and the instrument by means of which the intention is achieved. Therefore strategy theory and practice should be taught at all levels of warfare and for each war or armed conflict individually (Hughes, 1989, p. 75).

Robert Lyman is convinced that the operational level of warfare must be led by generals with a pronounced feeling for strategy (Lyman, 2008). There, nonetheless, exists a traditional belief that only command in military sense can be carried out at the operational level of warfare, without any political elements included 
(Gray, 2009). As warfare and the objectives defined as a military instrument are part of the external politics and the political will reality, the teaching of strategy can be quite a challenge.

A couple of basic questions to be answered prior the formation of the strategy education curriculum:

What can be required from a strategist?

Why are we educating future strategists?

What does it mean to be a strategist?

Colin Gray believes the following could be expected from future strategists:

- Theorize abstractly and contribute to the development, or more accurately the interpretation, of strategy's eternal and universal general theory.

- Conceive, invent, or discover, the master idea(s) that provide the basic guidance for planners in particular historical contexts.

- Shape and draft the actual historical operational plans, also known as strategies, for the use of the armed forces; this requires command and control of the process of strategic planning, including adaptive planning once the enemy begins to cast his vote.

- Command and control of the attempted implementation of plans. (Gray, 2009, p.13)

According to Kotnik senior officers should:

- Be capable of analytical integration which will ensure better understanding of the comprehensive strategic environment.

- Be able to manage a wide spectrum of activities surpassing the activities of a classical theatre.

- Be able to operate in different environments in which they will come across different races, religions, cultures etc. (Kotnik, 2008, p. 83).

Strategists must be able to direct, lead and form military operations the purpose of which is to secure the advantage obtained in the military area.

Troha states that "a strategic leader" focuses on the formation of the vision and the organization structure, and allocates resources and assets. He operates in unclear circumstances and deals with complicated and challenging problems which are influenced by events and organizations that are not part of the military" (Troha, 2009, p. 77). Strategists should also be able to form and direct military activities supporting the attainment of political objectives; "military commanders must be able to take on a multilayered and a complex role of a soldier-scientist and a soldier-diplomat" (Kotnik, 2008, pr. 82).

What should the strategists be educated in? 
Gray warns that the teaching of strategy should take into account the different roles a strategist can carry out, as well as the fact that strategy is a science not to be treated by the teachers (lecturers) as a never changing set of truths.

He is also convinced that education in the field of strategy should influence an individual, his behaviour and his conduct; a strategist should be a dynamic product or a mix of biology, psychology or character, experience and opportunity. The mere intelligence does not suffice for the attainment of the highest quality strategic conduct. Good tacticians are not always good strategists and good strategists do not need an exceptionally brilliant career in tactical warfare. In practice, however, an individual who has the potential to become a great strategist will never get the opportunity at the strategic level, if his performance of duties at the lower levels will not be satisfactory, even though if such duties do not correspond to his capabilities.

There are three closely intertwined developmental paths leading to a military leader at the strategic level: a selection process which ensures the selection of an individual with the most appropriate personal qualities and personal values; the formation of the organizational structure which enables monitoring, assessment and the rewarding of an individual through promotion to more responsible positions as well as education and training aimed at the development of knowledge (e.g. experience and findings) and conduct, both essential elements for an individual assuming the highest leadership positions (Troha, 2009, p. 77).

The strategy theory signifies a conceptual basis and the understanding of war. Is a tool which can be used for analyzing war and peace problems. The understanding of theory means that a student has both the concept and the questions which help him and guide him through further studies. The study of strategic theory helps us think strategically (Mahnken, 2010, p. 68).

The general theory of strategy is always important. It is the context in which strategy is applied that differs, most likely leading to significant differences in the contents. The challenge in this respect is, above all, to define the necessary topics for future strategists in relation to the history and context. It is much easier to reach a consensus on the contents of the general theory of strategy than to define which strategies should be applied at the present time and in the future.

Gray claims that the future strategists should be trained in a variety of different peacetime and wartime scenarios, as we cannot predict the type of conflicts that will require their professional skills. This training would, however, have to include also the classical form of warfare. Gray is a strong advocate of the revival of forgotten skills. He believes that we merely think that we understand conflicts of the new century and that it is dangerous to presume that contemporary conflicts are the same as the conflicts we will be confronted with in the future. To his belief the contemporary study approach to strategy should take into account the different conflicts and all aspects of such conflicts, even though this may not be the modern tendency or desire. 
How good can a general who has never commanded in an engagement be? How capable and efficient will the armed forces be in 2025 or 2030 ?

There are two sides to the issue of the teaching of strategists; On the one hand, military profession has been lacking real-life experience for years. On the other hand, strategic professions in the military are much more demanding than other professions, since strategy deals with the issue of national security and human survival. For this reason strategic education must be as realistic as possible.

Kotnik says that "war still demands both science and skills from (military) leaders" and that "creativity, intuition, leadership, motivation and the adoption of correct decisions", all attributes of skills or qualification and personal characteristics of an individual, remain the key factors also in the present-day theatre situation (Kotnik, 2008, p. 86).

Appropriate peacetime strategic conduct must be adaptable, flexible and adequate, and must enable operation in different types of conflicts and warfare. In the future, a military instrument able to support political decisions in that context will be required. Strategic education must therefore take into account historical experience, but must not be directed towards or rely exclusively on the study of contemporary history and the current events.

\section{What should we teach?}

The aim of the education programme is to provide strategists with quality knowledge and appropriate competencies, and not only the attainment top-notch results. The most important thing to teach a strategist is strategic assessment.

Gray presents seven areas in which strategists can gain appropriate knowledge.

1. To think strategically; to focus on activities which enable coping with consequences or results of decisions and to predict immediate (direct) and future effects of activities. To understand or justify the desired end state, the manner in which this state will be attained and the means to be used to this end.

2. Formal education in strategy is mandatory. Since war changes only in character but not also in nature, the general theory of strategy should be applied to all historical examples of war and conflicts.

3. Apply theory to contemporary examples of conflicts and war and assess the value of theoretical premises.

4. Understand the opponent and be able to adapt to new opponents.

5. Use healthy scepticism, critical and creative thinking and understand that these are strategic advantages.

6. Understand that strategy can function well enough to carry out specific tasks despite the scepticism and negative historical experience.

7. Be familiar with humanistic studies. Successful strategic operation depends on appropriate education and the worldliness of an individual. A strategist must be 
able to explain the current and future military activities to civilian high officials in a way they will understand them (Gray, 2009, p. 37-51).

Kotnik believes that future commanders will have to master combat and diplomatic skills and be capable of assessing activities "not only from the aspect of military effectiveness but also in the light of the influence of political, ethnic, linguistic and religious circumstances in the environment they are operating in" (Kotnik, 2008, p. 78).

Strategic conduct must therefore include the capability to make decisions, carry out command and control and the capability to understand events. To that end practical limitations of formal education in the field of strategy must be understood.

In addition, in order to define what needs to be taught, we also have to define who should the strategy students be, what do they have to achieve or do and what should they be taught and what not.

\section{THE CURRENT EXPERIENCE IN THE EDUCATION OF MILITARY STRATEGISTS IN SLOVENIA AS A GUIDANCE FOR THE FORMATION OF EDUCATION FOR FUTURE STRATEGISTS}

In Slovenia, the preparation of curriculum for military strategists started six years ago. In that time, Slovenia had a number of military and civilian experts who completed strategic education at the National Defense University and some other colleges in the USA, the Royal Military Academy in Great Britain and at the General Staff College in Germany. The drafting of the curriculum turned out to be very challenging as there was but a handful of people who had both the experience at the strategic level and a solid theoretical knowledge. The Faculty of Social Sciences, however, stepped in and helped with an expertise which was mostly theoretical.

Further on, the article presents the experience and the authors' proposals deriving from the attendance of the Military Strategy subject at the General Staff Programme in the Slovenian Armed Forces by one of the authors and the experience of both authors obtained during the performance of functions at the strategic level and the theoretical knowledge gained at strategic trainings.

\subsection{Strategy teachers}

During the process of preparation of the military strategy curriculum, Slovenia has gained a number of experiences which support the theoretical premises for the formation of the study of strategy.

The first important Slovenian experience has brought the realization that individuals who would be capable of teaching strategy should be identified already at the major or lieutenant-colonel level. Consequently, the planning of their professional and 
career development has to be provided for. They have to complete adequate military and civilian post-graduate studies, participate in the process of military education and training as instructors or as assistants in the strategy course and gain practical experience from engagement in command and control at the strategic level and return in the education process as strategy teachers with all the theoretical knowledge and practical experience. One of the key elements without which a national military higher-education school system cannot be formed is quality lecturers (Žabkar, Svete, 2008; SPOR09). ${ }^{2}$

In the future, effective cooperation between civilian and military actors for the formation of appropriate national security strategies will become increasingly important. Therefore the experience that better results in education can be achieved only through the inclusion of military and civilian experts, theoreticians and practicians with work experience from civil and military field in the teaching of strategy at the national and international strategic level in the form of permanent staff (co-workers).

The next challenge to be solved is the objective of the training or in other words the question "What is the desired end result?". Strategy students must develop the capacity to understand and reflect critically about skills and the knowledge for the formation and the use the national military power which can be used to support national interests. They have to develop critical thinking and the capability to use concepts and understand the current and future strategic challenges.

Up until the present time the curriculum of military strategy included topics on the theory of war and the military force, military strategy, war strategy, strategic planning, the planning of strategic resources, strategic planning for the future and the preparation of own (national) military strategy. It was practically impossible to carry out all required topics and meet the set goals completely, as they were too extensive and too demanding content-wise. These findings result in the following experience: we should set attainable objectives and support them with topics and exercises which can be carried out with the personnel and technical capabilities at hand. It is very difficult to lower the level of ambitions and expectations, however the

\footnotetext{
The key findings from the field of personnel selection to support the process of military education and training in the Slovenian Armed Forces in the context of the strategic review of the defence field carried out in 2009 were as follows: The personnel plan does not envisage the inclusion of expert personnel for the manning of duties within the education and training system: nor the education and training implementers nor those who provide for the uninterrupted execution of education and training processes; the mandatory directions for the SAF active component members career paths system even to the present day do not stipulate a planned development of personnel for the manning of duties within the education and training system; the majority of education and training implementers, working in centres which provide teaching personnel, and in military schools, attend supplementary andragogical and pedagogical training, but not before they are assigned to the new duty post; the personnel who does not have the appropriate knowledge and previous experience required for quality work in education and training and who do not see the work in the education and development process as a professional challenge are likewise assigned to schools and centres; we are not training military experts who are capable of independent and quality takeover and execution of basic military subjects from the field of education and training in the SAF; experts who would take over the execution of basic military subjects at the highest levels of education and training are also a problem.
} 
following principle "less is more" has to be applied for the definition of objectives, while the thematic scope of the education and the credibility of the programme has to be preserved. The set conduct, when execution becomes a formality but does not ensure the desired quality, has to be avoided.

In addition, the formation of the strategy curriculum also requires the definition of the type of strategists required. The experience shows that individuals who combine the capability to operate at different strategic areas of operation, such as strategic management, planning, the development of concepts and other areas are difficult to find in the education process. Therefore the curriculum has to be prepared in a way that supports the strengthening of the natural capabilities of students, thus providing for better education results.

\subsection{Strategy programme timeframe}

Another important experience was learnt; time is also essential for the attainment of the education objective. And so are the selection of students, preparation of the study process in a methodological sense (teaching methods and techniques), the selection of study material, comparison of curriculum with other programmes, courses (the upgrading, connection and the transfer of experience) and other activities.

The time available for the execution of a subject is a key factor for the attainment of curriculum objectives. There are 48 hours planned for the execution of the military strategy subject; for both lectures and practical exercises. ${ }^{3}$ In practice, the time available was much too short for a quality presentation of topics, therefore the lecturers had to decide by themselves what to exclude from the programme. The execution of the programme in the given timeframe presented an even greater challenge in the generation of students who attended the schooling while employed full-time; they attended the education one week per month at which the lectures lasted at least eight hours per day, followed by individual study. It is therefore important that the subject preparation process provides the lecturers with the freedom to assess and decide in which way they would like to address the topics. When time is limited, it is more important to address the key topics than to merely go over the prescribed content.

\subsection{The role of teachers in the selection of topics or the flexibility of syllabus}

The possibility of a flexible presentation of specific topics in the context of prescribed topics is important, as it enables the lecturer to include the discussions on and the experience gained from the current global or regional events. The lecturers must have the knowledge and the skills required to include real-life events in their lecture with the intent of encouraging discussion and application of the students' theoretical knowledge to current events. This provides the students with a possibility to educate

\footnotetext{
When Krek took over the Military Strategy subject in 2006, the subject was 48 hours long, which is the exact number of hours that the General Staff Programme curriculum encompassed in 2008 when Žabkar and Svete prepared a critical comparison of the programme with comparable programmes abroad (Žabkar, Svete, 2008, $p$. 202-203). The programme is, however, still applicable (Program, 2007).
} 
in the field of military strategy and helps them form their own strategy which could prove useful in an actual real-life situation. Strategy students can be an excellent professional audience for a critical assessment and supplementation off current strategic documents from the field of defence planning and doctrinal documents. Experience from practice to be applied in the preparation of the strategy curriculum show that the syllabus has to be flexible enough for the lecturer to include current events in the discussion and use them to support the theory. In this way, the lecturers provide for a higher quality execution of the course and includes the students' opinions in the preparation of the expert assessments of the current normative and expert national security documents.

\subsection{Study literature and material}

The study material used in the implementation of the strategy education is essential for quality education. There is currently a great variety of useful literature available in the English language, some of it in German, French, Italian and even Russian. Naturally, the limitation in the use of these materials are the lecturer's and the students' language skills. In the recent years, English language skills have considerably improved; however, the knowledge of other languages saw only little progress. Nonetheless, the greatest challenge remains the selection of the appropriate study material in the vast variety of all material available. It is relatively simple to select the material on the theory of strategy, on the identification of the use of strategy in history of warfare and in a number of modern conflicts. A much bigger challenge is the selection of the study material, which is appropriate for the examination of the strategy and military strategy of the Second World War in Slovenia, the Slovenia's War of Independence and the Balkan Wars after 1991, in short, the strategies which are of special national and security interest for Slovenia. There is more than enough material and books addressing the subject, however we have to identify the parts with expert explanations which could serve as appropriate study material. Hence the lecturer is often confronted not only with the task to prepare the study material, but to write it as well. A strategy lecturer must be able to produce quality study material addressing strategy issues.

\subsection{Interconnection of the strategy subject with other areas in the military education programmes}

Among other things, the experience gained from military education demonstrated the importance of relation to other subjects and courses or other education programmes. Also very important are the appropriate upgrading of knowledge and the joining of individual contents of different subjects under one single course and the interconnection between them. It is especially challenging to prevent repetition and to ensure the inclusion of important topics in at least one of the courses. During the drafting of curricula for different education programmes such interconnection between subjects can be attained only through professional coordination which has to be ensured also during the execution of programmes or subjects. 


\subsection{Education participants and their previous knowledge}

The strategy study programme should not be prepared without paying special attention to the education participants who enter the education process with different experience; some of them completed education abroad, their civilian and military prior knowledge differs, they have different language skills and different capability for preparing written papers at the postgraduate study level. Across the world certain strategic education programmes are attended by both civilian and military persons of different nationalities together (civilians and soldiers). It is very difficult to find a common premise which would serve as a basis for quality teaching of the subject if the lecturers have no influence over the curriculum requirements and are not familiar with the students' capabilities.

The quality of the lectures and the study can be increased through certain activities that facilitate the adjustment of the work method to the education participants. These are:

- Conducting interviews with education participants who will enter the education programme before the selection of participants and immediately afterwards;

- Preparing the selected material in advance; the material can be prepared for each individual and/or for all training participants, especially if the group of participants is large;

- Carrying out a preparation course to determine the level of knowledge. Based on the latter individuals are able to enter the education process without interruptions. This can be taken into account only if the lecturer has the possibility to determine an individual's experience and knowledge beforehand.

All of the listed activities can be carried out in practice even though an effective way for their execution might be difficult to find. A more feasible way is when the individuals obtain the knowledge required for successful inclusion in strategic education through a prior mandatory course (operational level). In the Slovenian example this means that a subject providing the basic knowledge on strategy (e.g. Strategy 101) to participants would be included in the Higher Staff Course syllabus.

\subsection{Monitoring the successfulness of the graduation candidates following the completion of the strategy studies}

There are two more experience relevant for further education on strategy in Slovenia; The work of those who have completed their education has to be monitored also in the future, especially when they take over duties at the strategic level of decisionmaking. The monitoring and assessment of their work results, also during this period, can improve their readiness and capability for the performance of strategic functions. It often occurs that individuals understand the operation of the national security system, the area of work and the responsibilities at individual functions/ duties at the strategic level up to the time they are confronted with real-life action, the influence of national politics and the civil society on the functioning of the system 
and the individuals. A particular problem at this level is an individual's incapacity to present strategic problems in a clear, unambiguous and comprehensive way. Even high officers occupying strategic positions, including those who passed education at the strategic level, are not versed in explaining professional arguments to civilian officials and politicians. On the other hand, civilian officials and politicians do not have the appropriate knowledge on national security which additionally hinders mutual communication and the assessment of issues which are often of national importance. In Slovenia, this problem was evident especially in relation to the question on the downsizing of the defence budget, assessment of certain more important programmes for the purchase of military equipment, the discussions on the cooperation of the Slovenian Armed Forces in Afghanistan and last but not least in the discussion on the abolishment of the Slovenian Armed Forces. Since we operate in an environment in which there are less and less available (financial and material) resources, political skills of high officers who are able to express the needs of the military in a persuasive and argumented manner, are becoming increasingly more important (Kotnik, 2008, p. 82-83).

Strategy students must be trained in the coping with challenges they will be confronted with at their strategic duties. They have to be versed in constructive discussion and be able to adequately explain professional military standpoints to both civilians and politicians. Already during their studies, the representatives of both the government and non-government organizations and the civil society are to be included in the education process. Strategy students have to be introduced to different circumstances and confronted with difficult questions regarding the resolution of the current crisis situations. Education at this level is their last systemic education or the last academic education during which they are free to express and defend their standpoints and opinion without their opinion having a negative influence on the defence and national security system.

Conclusion At present, a strategic education curriculum is being formed under the auspices of the Central European Forum of states for military education. The initiative resulted from the needs of the small states which were later joined by the large ones. A joint curriculum for the education of soldiers and civilians at the strategic level would facilitate the formation of the curriculum for individual countries. It would unify professional knowledge at the strategic level, which would support the cooperation between agencies not only within individual countries but also at the international level (Comprehensive Approach), especially in the decision-making and the implementation of activities connected to the world crisis. The exchange of lecturers especially for those subjects, for which they are difficult to ensure within the national framework, is envisaged. This will improve the quality of execution and contribute to the better understanding of the English language, since the course will be held in English. The planners of this curriculum in general tend to organize the lectures in the English language for all participants. The unified learning language would enable the countries to send their students abroad, while the only subjects they would attend in the homeland would be those that are exclusively of national importance, such as 
the exercises for the improvement of the operation of the system of national defence or any of its part and other similar contents.

Slovenia has to continue to be actively involved in the formation of the joint strategy curriculum and its actual realization, to support initiatives which would facilitate the study and support its quality. A small army, such as Slovenia's, will have to learn how to better exploit the different possibilities for a quality professional training of personnel and for the obtainment of better results in relation to the resources and the time invested also in the future. However, it is important to take on an active role in such initiatives, as we have both the experience and the knowledge we do not have to be ashamed of.

The politics has to support our efforts to provide the best quality lecturers, students and programmes for the study of strategy. Without a doubt, a course the objective of which would be the familiarization of the members of parliament and the Government and other important political officials with the system of national security and especially with the matters pertaining to the defence system, would prove to be more than suitable and significant, as it would contribute to the improvement of the general knowledge, familiarization with terminology in the defence field and the knowledge required for work and, in particular, for making decisions at the strategic level.

\section{Bibliography}

1. Gray, C. S., 2009: Schools for Strategy: teaching Strategy for 21 ${ }^{\text {st }}$ Century Conflict, http:/ www.StrategicStudiesInstitute.army.mil, 5 January 2012.

2. Hughes, W. P. jr, 1989: The Strategy-Tactics relationship. V Colin S. Gray and Roger W. Barnett, ed. Seapower and Strategy. Annapolis, MD, Naval institute Press, 1989, Chapter 3.

3. Lyman, R., 2008: The Generals: From defeat to Victory, Leadership in Asia, 1941-1945. London, UK, Constable.

4. Kotnik, I., 2008. Kakšen naj bo sodobni častnik Slovenske vojske in kako do njega. Bilten slovenske vojske. 2008-10/No. 1.

5. Allen, C. D. 2010. Redress of Proffesional Military Education, The Clarion Call. Joint Forces Quarterly, 59, 4th Q 2010.

6. Bethel, S. A., Aaron Prupas, Tomislav Z. Ruby, Michael V. Smith, 2010. Change Culture, Reverse Careerism. Joint Forces Quarterly, 58, 3rd Q 2010.

7. Mahnken, G. T., 2010. Strategic Theory. V Baylis J., Wirtz James J., Gray S. Colin, ed. Strategy in the Contemporary World, Oxford, p. 67-81.

8. McCausland, J. D., 2008. Developing Leaders for 21.st Century. Strategic Studies Institute, USA.

9. Program generalštabnega šolanja, 2007. MOD RS, No. 603-63/2007-2 dated 19 April 2007.

10. Salmoni, B. A., Hart J., McPherson R., Winn Aidan K., 2010. Growing Strategic Leaders for Future Conflict. Parameters. Spring 2010.

11. Strateški pregled obrambnega resorja 2009, publically available version, http://www. mo.gov.si/fileadmin/mo.gov.si/pageuploads/pdf/ministrstvo/SPOR2009.pdf, 15 February 2012.

12. Troha, N., 2009. Usposabljanje voditeljskih veščin: modna muha ali potreba-Pomen vadišča za usposabljanje voditeljskih veščin pri razvoju voditeljev. Bilten slovenske vojske $2009-11 /$ No. 4.

13. Žabkar, A., Svete, U., 2008. Šolanje vojaških profesionalcev med tradicionalnimi izhodišči in (post)modernimi izzivi. Bilten slovenske vojske 2008-10/No. 1 . 


\title{
TRANSFORMACIJSKI IZZIVI ZA VARNOST NA SLOVENSKEM MORJU
}

\author{
TRANSFORMATION CHALLENGES TO SAFETY \\ AND SECURITY AT SLOVENIAN SEA
}

Povzetek Sodobno varnostno okolje na morju je čedalje bolj kompleksno, grožnje pa so nepredvidljive in lahko povzročijo dolgotrajne posledice. Klasična in birokratska organizacija subjektov varnosti na Slovenskem morju ne bo mogla dolgo slediti varnostnim izzivom. Ti zahtevajo nove pristope in oblike organiziranja zaradi povečanja zmogljivosti in učinkovitosti delovanja ter racionalizacije porabe javnih sredstev. Vsestranski pristop, sodelovanje in koordinacija ali pa celo integracija različnih služb varnosti na morju so nekateri odgovori na vprašanja sodobnega varnostnega okolja.

Ključne Pomorska varnost, vsestranski pristop, koordinacija, integracija.

besede

Abstract Modern security environment at sea is increasingly complex, while threats are unpredictable and can have long-term consequences. The classic and bureaucratic way of organizing different safety and security services responsible for Slovenian sea will not be able to keep up with modern security challenges for a long time, since these require new approaches and forms of organization. The main aim is to increase the capabilities, efficiency and effectiveness of operations and at the same time to rationalize the use of public finance. Comprehensive approach, cooperation and coordination or even integration of various sea safety and security services may be the answers to the modern security environment.

Key words Maritime safety and security, comprehensive approach, coordination, integration. 
Introduction The sea is of major economic, political and military importance to Slovenia. The Port of Koper with its position in the far north of the Adriatic Sea provides optimum conditions for economic flourishing of the Slovenian coast and the inland of the country. Slovenian sea also functions as a sea gate for several Central European countries, with the Port of Koper being the leading transhipment port for Austria in 2010, for 33\% of all Austrian goods shipped by sea (http://www.verkehr. co.at, 10.06.2011). It is important that Slovenia develops own means for its protection, either independently or in cooperation with the Alliance. Can the existing safety and security organization on Slovenian sea successfully meet the challenges of time? Is the public spending for sea safety and security cost effective? Does Slovenia have adequate material and personnel resources? Is Slovenia developing sea defence and security concepts? Those are just some of the professional issues to be addressed as part of the future transformation process in the field of defence and the wider security. However, the first issue to be raised is the existence of political will in Slovenia for fundamental reforms to be able to reflect on transformation of defence and the military as known in Western countries, and of the entire security sector as part of complete renovation of public administration. Podbregar argues that the environment, and Slovenian politics in particular, has a very opportunistic approach towards the Slovenian Armed Forces and is only rarely prepared to address its development needs being the ultimate constant factor of any military.

In the past, the Slovenian Armed Forces successfully responded to transition challenges and implemented the relevant objectives in several areas. Worth mentioning is particularly the efficient organizational downsizing and personnel reductions, which were aimed at enhancing operational effectiveness while maintaining the core of forces and capabilities which would efficiently meet the challenges of contemporary security environment in cooperation with the allies (Šteiner, 2010). Transition was also successfully managed by maritime forces currently representing approximately $1.3 \%$ of the entire Slovenian Armed Forces' structure. From scratch, during the time of Slovenian war of independence in 1991, an enviable security entity has started to emerge on Slovenian sea to evolve after 20 years into the $430^{\text {th }}$ Naval Division. The unit has undergone several reorganization stages in accordance with the Slovenian Armed Forces' (SAF) development concepts and in line with the challenges of security environment. The last reorganization took place when the unit acquired a new multi-purpose boat TRIGLAV11.

Contemporary threats at sea are far more unpredictable and intense than those 20 years ago, as well as long-lasting in terms of their impact potentially causing damage that cannot be repaired for years if not decades. It is therefore, from the security perspective, important to develop such capabilities and organization at sea to ensure timely awareness of threats and, at the same time, efficient response to suppress or remove risks. One the other hand, one should be aware that modern capabilities cannot be developed exclusively for one type of threats or protection of one's own »little garden «, but should rather involve multi-purpose forces capable of conducting the full-range of operations in the framework of comprehensive approach to safety 
and security at sea. According to Podbregar, we are entering the period of highly trained, competent leaders and the period lacking precious coordination time for the resolution of threats and crises (Podbregar, 2011). In short, there is a need for standing forces, organized into a flexible structure with clearly defined procedures, equipped with advanced technology, integrated, and manned with qualified staff capable of cooperation at home and beyond national borders.

\section{THE SEA AND SECURITY CHALLENGES}

\subsection{Complexity of global security environment}

Peace, security, stability and development are becoming increasingly interconnected, and demand enhanced cooperation and coordination of countries and international organizations as well as other non-state actors in various fields. In the future, the international security environment will be challenged above all by climate change, unfavourable global demographic, financial, economic and social movements, limited natural and other strategic resources, uncontrolled trade in sensitive materials and services, the deepening differences between the rich and poor parts of the world, crisis areas, emergence of new forms and nature of conflicts as well as various globalisation effects. A permanent source of threats is also natural and other disasters, the intensity and frequency of which are increasing as a result of climate change and environment overburdening.

\subsection{Contemporary security threats at sea and appropriate response}

Sea routes are still cheapest and, hence, massively exploited, but also highly vulnerable to modern threats. In terms of their scope, threats at sea can be divided into national, supranational and global, and into military, non-military and natural disasters in terms of their origin. According to current assessments, military threats are at their minimum, but can still not be ignored. The division line between measures and the necessary deterrent forces is no longer clear. The sea is turning into a man's living environment, the navigation space for huge oil tankers, supper passenger and other ships accommodating over 5000 people on board, which can become highly attractive targets for pirates and terrorists.

NATO regards terrorism as one of the key threats of modern era, which was the main reason for launching the NATO-led operation Active Endeavour in the Mediterranean. As the only NATO-led operation conducted so far under Article 5 of the Washington Treaty, the operation should serve as the sign of solidarity to the US in the aftermath of 11 September 2001 terrorist attacks (http://www.manp. nato.int/ operations/Active Endeavour/, 16.05.2011). For the time being, Slovenia has no maritime forces available for participation in the operation, but can make an important contribution in the field of intelligence by sharing the information with the allies on potential sea threats. The «need to know « principle applied recently is now being transformed into the $»$ need to share « principle (Maritime security: NATO and EU roles and coordination, http://www.nato-pa.int, 02.06.2011). 
The modern form of piracy emerged in the early $21^{\text {st }}$ century in the Indian Ocean in the vicinity of the Somali Horn. Nowadays, Somali pirates use primitive vessels and weapons for disturbing the movement of large cargo ships, crew kidnapping, and enforcing high bribes. Despite their simple tactics, they have caused the rise of insurance premium on sea cargo and inflicted large economic damage. With the European Union counter-piracy operation ATALANTA ${ }^{1}$ in the Gulf of Aden, the international community has succeeded in reducing the number of kidnapped ships since 2008 despite the enlarged operational area of pirates. The area of piracy operations is expanding far into the Indian Ocean, up to India and the Arab's Gulf as well as along the south-eastern coast of Africa (Žabkar, 2011). NATO participates in the counter-piracy operation ${ }^{2}$ with the Maritime Security Centre and military vessels carrying out control and monitoring of ships at sea.

Europe has become a target for many economic and forced migrants, many of whom arrive by sea. In Europe, North-African migrants represent currently one of the biggest migrant groups. To them, European countries are promised lands (Italy - Lampedusa). The continuous increase of their numbers may have an impact on stability in the wider area of South Europe. The decision reached by the Italian Government in April 2011 to grant African migrants temporary European visas has triggered a strong reaction by France regarding the implementation of stricter control measures on the border with Italy. The problem should definitely be addressed comprehensively within the international community, i.e. the EU in this particular case. Slovenia is regarded as the country of destination by many migrants coming mostly from the Balkans' countries, which emerged after the dissolution of the former common state of Yugoslavia. The trends in migration flows are changing and depend upon the circumstances in the region and the economy in Slovenia. Migrants from the Balkans usually do not use sea routes, as land routes are far more convenient for them. The likelihood of an uncontrollable outbreak and spreading of contagious diseases additionally increases migration of the population, natural disasters and terrorism.

Modern society depends heavily on uninterrupted and reliable functioning of information systems. Any system malfunctions may therefore represent a serious threat to the activity of public and private sectors in general, notably to the principal functions of the state and society. Owing to the diversity of information and communication systems, the free cyber space and problems associated with its control, the spreading of various forms of computer crime at sea, especially cyber attacks against governmental and non-governmental entities which cannot be limited in space and time, are also likely.

\footnotetext{
ATALANTA is the European Union's first naval operation. It was launched on the basis of UN Security Council Resolutions 1814, 1816, 1838 in 1846 adopted in 2008, Resolution 1918 adopted in 2009 and Resolution 1970 adopted in 2010. http://www.eunavfor.eu/ (27.04.2011).

2 Since 9 October 2008, NATO has participated in the fight against piracy off the Horn of Africa as part of Operation Allied Provider ensuring military escort for convoys of merchant ships. On 17 August 2009, Operation Ocean Shield was launched with the same mandate as the previous one and even more comprehensive approach by preparing domestic capabilities for the fight against piracy. http://www.manw.nato. int/page_operation_ocean_shield.aspx (18.05.2011).
} 
Earthquakes, volcanic eruptions, floods, storms and fires have accompanied mankind since its very beginnings. Nowadays, we are also witnessing other disasters, such as air pollution, spills of hazardous materials at sea, nuclear accidents etc., which are all the consequences of man's impact on nature. The impact is multi-layered, ranging from economic, environmental, demographic and also to political domains. The economic logic of environmental effect, climate change and disregard for past experiences intensify the adverse impact of natural disasters. The entire northern Adriatic Sea is a gulf-type sea, where the negative influence of individual factors on its quality is bigger than in deeper and high seas. The biggest potential risk of pollution with catastrophic dimensions comes from big tankers navigating $3-5 \mathrm{~km}$ off the Slovenian coast, and from big off-shore warehouses for oil, oil derivatives and chemicals. Apart from stranding, collision, fires and explosions on ships, there is also a high risk of spills during loading and unloading of ships' cargo or fuel. As there is a strong likelihood of such pollution, prevention measures must be strictly enforced. This demands a well-organised and equipped service which will ensure effective sea protection either independently or as part of a joint national service in charge of sea security in its largest sense.

\section{ORGANIZATION OF SECURITY SERVICES ON SLOVENIAN SEA}

\subsection{The basis for the organization of security services at sea}

Slovenia's maritime orientation was already recognized at the first democratic Assembly of the Republic of Slovenia on 7 March 1991 with the adoption of the Resolution on the Maritime Orientation of the Republic of Slovenia, which preserves the advantage of the exit to the Adriatic Sea. The resolution, among other things, states a clear intention of the Republic of Slovenia to pursue maritime-oriented economic and development policy. To this end, Slovenia will support the development of the Port of Koper and, through the port-based transit and land traffic, further the enlargement of permanent sea routes, protect the public interest in port operations, pilotage, towing, rescue and passenger maritime transport, provide conditions for the development of cargo shipping which will be able to do business in the global market, systematically promote acquisition of food and other products from sea, and ensure legal arrangements in compliance with international rules, and will therefore (Resolution on Maritime Orientation of the Republic of Slovenia, Official Gazette of the Republic of Slovenia, no.10/91):

a) Set up a service or services in charge of control of the sea and the coast in terms of security, navigation, ecology, sanitary-health and fiscal aspects;

b) Regulate sea border control;

c) Reach comprehensive agreement with its two maritime neighbours on maritime navigation routes and regimes as well as fishing areas in the Adriatic Sea.

Based on resolution stipulations it can be concluded that the provision of security, safe maritime transport and protection of sea are in the national interest of the Republic of Slovenia. Geršak maintains that Slovenia is faced with challenges 
and has to be prepared to counter both conventional and the increasing number of asymmetric threats from and at sea. For this reason, the national security system of the Republic of Slovenia must take into consideration military and non-military sources of threats in national security, irrespective of their origin. Various sources of threat are interconnected. Occurrences in a specific area of society may also have an impact on the other, thereby increasing the threat level. Such threat concepts demand high adaptability of the national security system of the Republic of Slovenia. It is also important for Slovenia's strategic security environment to constantly monitor, analyze and make authentic assessments, bearing in mind at the same time that the causes of conflict situations in the international community can only be managed through enhanced cooperation and joint operation (Geršak, 2008).

\subsection{Capabilities for providing security on Slovenian sea}

Threat deterrence capabilities are within the national security system of the Republic of Slovenia connected mainly to sub-systems of traffic, internal and defence security. Moreover, all other sub-systems, such as systems pertaining to the environment, economy, finance, protection and rescue, and education, which through their operation support the effectiveness of primary services on Slovenian sea as well as the wider international community, should also be taken into account. Sea securityrelated tasks in the widest sense of the word are currently being performed by the following services: Maritime police, Port state control, $430^{\text {th }}$ Naval division, Service for protection of coastal sea, Regional office of the Administration of the Republic of Slovenia for Civil Protection and Disaster Relief, Service for protection of sea of the Port of Koper, Koper customs office and Marine biology station. These services are organized as government agencies or as part of the Port of Koper Company. A simple analysis shows that there are 31 vessels altogether available for their use, which are mainly small and cannot perform tasks under rough sea conditions when the need for providing security usually arises (Žnidar, 2011). The issue of rationality in equipping sea security services with vessels of limited capacity is well founded. Deriving from the fact that Slovenia, on the one hand, is a relatively small maritime country, and that the occurrence of modern, increasingly unpredictable threats at sea, on the other hand, demands continuous situation monitoring and rapid and efficient responsiveness, the efficiency of security services' fragmentation on Slovenian sea becomes highly relevant.

\section{POSSIBLE APPROACHES TO SEA SECURITY ORGANIZATION}

\subsection{Comprehensive ${ }^{3}$ approach to providing security at sea}

Against the background of security threats and threat complexity in the future it can be concluded that individual operations of security services anywhere in the world, and similarly on Slovenian sea, will not bring the desired results in the future, i.e. it will be neither effective nor efficient or even successful. There will be a need for

3 Comprehensive Approach as a term has two equivalents in Slovene resources and may denote completeness and comprehensiveness. 
cooperation, exchange of information, coordination and mutual assistance. According to Androjna, Slovenia has embraced a two-tier approach involving enhanced regional and multinational cooperation on the one hand, and better solutions and interagency coordination on the national level on the other (Androjna, 2010).

One of the possible modus operandi and greater efficiency of sea security services is embodied in the comprehensive approach, which can play a decisive role in ensuring success of modern operations, whose character is becoming increasingly civilianmilitary rather than military. This approach involves joint operational and mission planning and preparation, regular mutual coordination, consultation, and operation of all military and non-military actors in line with the contemporary approach of crisis management (US JFCOM, 2008).

The key areas of comprehensive approach are: joint planning and operations, lessons learned, close cooperation with non-military actors, public diplomacy, and stabilisation and reconstruction. Operational planning itself demands continued gathering of information and corrections of plans up to the conclusion of an operation. Amendments must be based on prudent monitoring and analysis of the impact of one's activities. The planning part should clearly define the desired impact of individual activities enabling the defined operational objectives. In addition to planning specific activities, their desired objectives, the possible impact and desirability should also be assessed. This can be achieved though continuous gathering, supplementing and analyzing of all relevant information before, during, and also after the operation or mission. It should also be mentioned that the world is flooded with data and messages, various perceptions of data capture, and that only a limited number of them are processed as information. Quality and comprehensible information of reasonable size can be key to greater efficiency of the comprehensive approach in providing security at sea. In addition to the information exchange, security at sea based on comprehensive approach also demands confidence among the stakeholders. The advantage of the comprehensive approach in providing security at Slovenian sea derives from the fact that no legislative changes and additional financial investment are required to increase its efficiency. On the other hand, it is necessary to clearly define the objectives, to master extensive knowledge and information, to ensure uniform understanding of standards, and to, above all, create the atmosphere stimulating the will and needs of all actors for participation in the processes leading to the fulfilment of desired objectives. The biggest disadvantage of such an approach still remains the need for developing a large body of security services, which requires major investment into equipment and training as well as standardization of processes and equipment on the one, and preparedness of services for cooperation on the other hand.

\subsection{Coordination of sea services}

On an initiative by a member of the RS National Assembly, an interagency working group was established in 2002, which explored the possibility of establishing an independent joint service for sea-related tasks or a coordination body dealing 
with coordination of all security services on Slovenian sea. In accordance with an analysis based on $\mathrm{SWOT}^{4}$ method, the group submitted a recommendation to the Government in 2003 to set up coordination of sea services, which was formalized with the Government decision of 31 August $2006^{5}$. Coordination is carried out on two levels: on strategic level as Sea service coordination, and on operational level as Operational maritime coordination. Sea service coordination has the following members:

a) Ministry of Infrastructure, Slovenian Maritime Administration;

b) Ministry of the Interior, Police, Police Directorate Koper;

c) Ministry of the Environment and Spatial Planning, Environmental Agency;

d) Ministry of Finance, Customs Administration of the Republic of Slovenia, Koper Customs Directorate;

e) Ministry of Defence, Slovenian Armed Forces, Force Command;

f) Ministry of Defence, RS Administration for Civil Protection and Disaster Relief;

g) Ministry of Foreign Affairs, European Affairs and Bilateral Political Relations Directorate;

h) Ministry of Agriculture, Forestry and Food, Agriculture, Forestry and Food Inspectorate of the Republic of Slovenia.

Operational coordination and the actual implementation of tasks related to Sea service coordination is carried out through the Operational maritime coordination (OMC) consisting of:

a) Slovenian Maritime Administration, Maritime Division - Harbour Master's Office;

b) Police Directorate Koper, Maritime Police Station Koper;

c) Koper Customs Directorate, Piran Branch Office and Port of Koper Branch Office;

d) Environmental Agency, Adriatic Sea Area Division;

e) Agriculture, Forestry and Food Inspectorate of the Republic of Slovenia, Hunting and Fisheries Inspection Service;

f) Slovenian Armed Forces, Force Command, $430^{\text {th }}$ Naval Division;

g) Administration of the Republic of Slovenia for Civil Protection and Disaster Relief, Koper Branch Office.

The tasks of Sea service coordination and Operational maritime coordination involve primarily:

h) Management of common sea issues;

i) Processing and analysis of sea situation;

j) Recommendations for the improvement of sea situation to achieve better efficiency and expeditious accomplishment of tasks as well as rational use of available technical means, coordination of work among individual bodies involved in Sea service coordination and Operational maritime coordination;

k) Cooperation with other bodies dealing with activities at sea;

1) Information services for competent authorities dealing with sea security issues;

\footnotetext{
4 Advantages/weaknesses (internal factors), opportunities/risks (external factors)
}

5 Decision by the Government no. 37300-2/2006/8 dated 31.08.2006. 
m) Development and promotion of activities for enhanced safety and security, and efficient rescue and search operations at sea.

Geršak mentions that operational coordination meetings are recorded in the minutes and that some key decisions were made (Geršak, 2008), as follows:

a) The Ministry of the Interior and the Ministry of Transport shall draft an agreement on the integration of police maritime radar with automatic identification system of the Slovenian Maritime Administration into a joint maritime traffic surveillance system;

b) A proposal for the establishment of maritime meteorology and hydrology service should be initiated and submitted to the Ministry of the Environment in order to draft documents for further discussion at the RS Government level;

c) The inspector of the fishery sector should gather the required information on the access of Slovenian Maritime Administration and Police Directorate Koper to the fishing vessel monitoring system;

d) A uniform maritime information system (UMIS) should be set up combining the data from the system of individual government bodies - members of sea coordination services and European Maritime Information System (SafeSeaNet) ${ }^{6}$.

According to the opinion of Head of Koper Harbour Master's Office, Davorin Fantulin, the various bodies of government agencies function well, even so well that Slovenia's example was followed by the EU in the establishment of the common European coast guard. As the systems and the legal basis for maritime monitoring are far too different in individual countries to have a common denominator, it was decided to create sea service coordination similar to the one established in Slovenia. The advantages of coordination operations can have an immediate effect reflected in formal cooperation and resolution of security issues and sea safety at joint meetings, regular mutual notification and acceptance of initiatives for improved sea security. The analysis of meetings shows that some significant initiatives have been adopted with a potential to increase the efficiency of all sea security services. The majority of sea services is satisfied with the established coordination or simply accepts the current situation. The key issue of whether the existing organization is sufficiently efficient and effective remains, however, unresolved. A mention should be made here, though, that the equipment and asset maintenance processes as well as personnel training are carried out entirely separate in individual government agencies, which influences both the cost and standardization of equipment as well as efficiency of joint sea operations.

\footnotetext{
SafeSeaNet is an information system set up by the European Union to provide quick and efficient data exchange among maritime authorities of member states. The system enables improved response of competent authorities during disasters and emergency situations at sea, including search and rescue, as it enables improved monitoring of ships during movements and in ports, helps improve the efficiency of port logistics and response time during search and rescue operations as well as facilitates maritime safety, protection of environment against and during pollution of sea, and supports other sea services, such as the customs, police, military etc.
} 


\subsection{Integration of sea security services}

The rapidly changing strategic environment and modern sources of threat necessitate not only information exchange and coordination, but also cooperation.

The establishment of a joint sea service, the Coast guard of the Republic of Slovenia, was a topic of discussions by the Maritime Board of the Republic Assembly as early as in 1991 and 1992, which was then abandoned. Soon after that the first maritime unit of independent Slovenia was established, the $430^{\text {th }}$ Maritime Detachment, the predecessor of the current $430^{\text {th }}$ Maritime Division. In 2002, the RS Parliament member Aurelio Juri re-launched the initiative for the establishment of a working group to explore possible forms of sea service organization. The governmental working group finalized its work in early 2003 and submitted a proposal to the RS Government with the following conclusions (http://slovensko-morje.net/sm_staro/ obalna_straza.htm, 20.06.2011):

a) Sea services are poorly equipped;

b) Services are understaffed;

c) The legislation regulates the powers, obligations and organization of individual government agencies, which allows for a relatively autonomous operations of services;

d) The merging of services would require changes to applicable laws of individual agencies or development of new legislation on sea security;

e) The merging of structures at that time could lead to reduced efficiency or even disbandment of services;

f) Sea security would be best provided through coordination of services.

The majority of the working group members shared the opinion that the merging of sea services was a political project and solution for the Maritime police, which had technical problems with its vessels. Various interests of ministries should also be mentioned in this regard, in particular the issue of assigning the leading role in the integrated structure of sea services and the associated finance control. In August 2010, the Parliament member Franco Juri re-launched the initiative on the establishment of the coast guard as a joint service on Slovenian sea, following the procurement of the multi-purpose boat Triglav and the discussions on the Resolution of the long-term programme of equipping the Slovenian Armed Forces up to 2025, which, however, evoked no serious discussion. Despite several political initiatives in the past, the initiatives stemming from the years 2002 and 2003 stimulated the widest professional debate so far. Nowadays, the situation is changed in many different ways; for one thing, the services' personnel and material resources have improved and consolidated in terms of their organization. The nuclei of experts have been created to successfully manage sea security processes. At the same time, the need for more efficient and rational organization of sea security organization developed, possibly involving integration of services, which can be linked to at least three reasons:

a) There is a big number of small government sea services differing in their organization, management and equipment, particularly in terms of their vessels. 
b) Despite the big number of vessels, these vessels are mainly small and have limited capabilities to operate under difficult conditions.

c) The country is faced with a severe economic crisis diminishing national stability and already reflected in the security system, notably in the defence sub-system and the Slovenian Armed Forces.

This can also be the time for more prudent reflections and substantial security and defence reforms, including the field of security on Slovenian sea. Moreover, it should be assessed whether today the integrated structure of security services on Slovenian sea would ensure better efficiency and effectiveness, resulting at the same time in greater operational efficiency. In this regard, positive experiences and conclusions of the 2009 Strategic defence review and reform experiences of international security sectors could be applied, in particular NATO-related experiences from the transformation of its armed forces and NATO structure as a whole. A starting point for the integration of various government agencies responsible for security on Slovenian sea could also be a new concept of joint capabilities and target forces without interference with administrative bodies and their sea powers, at the same time facilitating creation of joint capabilities under joint leadership. This would also entail the definition of the legal basis for operations and relations among administrative bodies and joint capabilities functioning as in the executive role. The advantages of such integrated structure would be manifold:

a) The objectives of ensuring efficient security of all people and material means on sea and maintenance of clean sea would be put in the foreground;

b) Integrated capabilities would be managed jointly which would simplify the management system, consequently resulting in better decision making efficiency;

c) A smaller number of more efficient vessels would be needed.

d) The vessels would be standardized, thereby allowing for more efficient management and rational maintenance, or, in short, establishment of integrated logistics;

e) The education and training system for maritime staff would be simplified and unified, thereby resulting in higher quality of training programmes and personnel;

f) Greater operational efficiency, especially round-the-clock operation according to the $7 / 24^{7}$ principle, would be ensured thus contributing to better control of the maritime domain (including maritime border) and readiness level for rescue at sea. A joint service would permit planning of operational cycles and continual operational capability of vessels.

g) Minimum investment would ensure infrastructure for all vessels. At present, the vessels are moored at various berths and under various conditions. The high berthing rent they pay comes from taxpayers' money;

h) A unified maritime operations centre would be set up at sea facilitating simple and rational links with sensors (radars, AIS, sonars, night vision devices etc.) and weapon systems. 
Integrated structures, however, should not be evaluated solely for their positive characteristics but also with reference to their disadvantages and weak points, in particular:

a) The legal basis requiring political consensus. Previous experiences show that reaching a consensus can be very difficult, even on matters of key national interest;

b) Possible disagreement among individual ministries about responsibility and authority over managing integrated capabilities could therefore be resolved through an autonomous government service or through appointment of one of the agencies for procurement and maintenance of assets and training. According to relevant past experiences, the Ministry of Defence has developed a good system;

c) The initial negative impact on sea operations due to the fact that the equipment and standards of personnel qualifications differ significantly. Through prudent merging of capabilities and planned personnel training the impact could be reduced;

d) Orientation towards peacetime tasks and along with this a strong likelihood of reduced military capabilities at sea. The issue of whether the military would fit into such integrated structure is therefore logical. Experiences from the world and home as well show that the navies have a special status and also tasks going beyond the internal affairs making them a strong element of the country's foreign policy.

Conclusion Slovenia belongs to one of the smaller maritime countries with a total of $46,6 \mathrm{~km}$ of the coastline, the sea covering an area of approximately $180 \mathrm{~m}^{2}$ and the international port of Koper in the Gulf of Trieste in the northern part of the Adriatic Sea stretching deepest into Central Europe. The Gulf of Trieste as a relatively closed gulf with shallow sea provides relatively limited navigation possibilities for larger vessels, with, however, more than 5000 of them navigating in this area annually. With the classic military threats at sea having almost disappeared, new and more intense threats are emerging, such as the weapons of mass destruction, terrorism, piracy, oil wells, tankers, nuclear technology, gas terminals etc. The development of modern technology is so rapid and all-encompassing in spite of high security standards that standards cannot be met, which can have major and far-reaching consequences for the environment and people. On the other hand, a large portion of the world's population is not in position to keep up with the swift progress, resulting in new forms of organized crime and shaped in its most cruel form as terrorism against the civilian population. The international law of the sea stipulates the rights and obligations through conventions, although practice shows that not everything can be resolved through rules. It would be wrong to think that contemporary security threats at sea cannot be resolved; on the contrary, the constantly and rapidly changeable security environment demands a flexible and comprehensive approach, and ongoing coordination of interests. This should involve participation of all actors, both governmental and non-governmental. As a maritime country, Slovenia is aware of security challenges and threats at sea, which is also reflected in its politics and efforts towards establishing conditions for the development of the naval domain, 
notably through the adoption of legal documents and programmes, support of the development of naval units and sea security. At the same time, active participation of navy professionals contributes to successful management and implementation of projects in this area of work. Security of the Slovenian sea represents one of the major areas of activity, as secure and stable sea situation is of great advantage to the development of the maritime economy. On Slovenian sea, this includes formalized coordination of sea services functioning both on operational and strategic levels. In the past, that was a suitable form for cooperation and resolution of sea security issues, however, with no regard to the measurement of effectiveness and operational efficiency. The reform of security sector including the transformation of defence would therefore represent a big challenge for all security services operating on Slovenian sea. Foreign experiences, especially those of the US and other NATO members, can be used as guidance with a critical judgment of their solutions and adjusted integration into Slovenian environment.

The complex modern security environment and the need for timely and quality information as well as efficient operation demand standardization of equipment and processes, and an effective decision-making process. Should the coordination of sea services and the comprehensive approach to safety and security on Slovenian sea represent the first two steps towards better efficiency and success, the integration of sea capabilities may be the end state providing the answer to modern security challenges at sea. The merging of operational structures and capabilities could lead to the reduction of vessels and hence to rational procurement and maintenance as well as harmonization of standards. On the other hand, we could afford more advanced vessels with higher capacity for continuous operation, also under difficult sea conditions during an increased security threat.

1. Androjna, A., 2010. Comprehensive Approach to Maritime Security of the Republic of Slovenia. Bilten SV 10/1, 192-201.

2. A cooperative Strategy for 21st Century Seapower, 2007. US Department for the Navy, US Marine Corps, US Coast Guard.

3. Booth, K., Wheeler, J. N., 2008. The Security Dilema-Fear, Cooperation, Thrust, Palgrave Macmillan, New York.

4. Časopis Seehafenbilanz z dne 10. junij 2011, št. 23. http:/www.verkehr.co.at, 17. 6. 2011.

5. Črnčec, D., 2010. Slovenija v geopolitičnem in geostrateškem okolju 21. stoletja, Bilten SV, junij 2010 - 12/št. 2, str. 55-56.

6. Geršak, B., 2008. Mednarodni vidiki zagotavljanja varnosti pomorskega prometa: Študija primera akvatorija Republike Slovenije, PŠŠ, Poljče.

7. Maritime Security: NATO and EU roles and co-ordination, http://www.nato-pa.int/default. asp?SHORTCUT=2087, 9. 2. 2011.

8. Podbregar, I., et.al, 2010. Informacija kot »bojna« podpora kriznemu odločanju, krizni komunikaciji in delovanju. Zavod za varnostne strategije pri Univerzi Maribor. Ljubljana.

9. Podbregar, I., 2011. Talka kampanjskega odnosa politike. Dnevnikov objektiv z dne 28. 5. 2011, str. 6.

10. Resolucija o splošnem dolgoročnem programu razvoja in opremljanja SV do leta 2025 , Uradni list RS, št. 99/10.

11. Resolucija o pomorski usmeritvi RS, Uradni list RS, št.10/91. 
12. Resolucija o nacionalnem programu razvoja pomorstva Republike Slovenije (ReNPRP), Uradni list RS, št. 87/10 z dne 3. 11. 2010.

13. Šteiner, A., 2010. Med tranzicijo in transformacijo. Bilten SV, junij 2010, št.12/2.

14. US JFCOM, 2008. The Comprehensive Approach: A Conceptual Framework for MNE5. Norfolk: USJFCOM.

15. Žabkar, A., 2011. Nova žarišča napetosti. Predavanje slušateljem 6. GŠŠ, Ljubljana.

16. Žnidar, I., 2011. Zaključna naloga na GŠS̆: Vpliv transformacije obrambnega resorja na zagotavljanje varnosti na Slovenskem morju, PŠŠ, Maribor.

17. http://www.stratfor.com/analysis/20110127-somali-piracy-annual-update (18. 3. 2011).

18. http://www.eunavforeu/ (27. 4. 2011).

19. http://www.manp.nato.int/operations/ActiveEndeavour/Endeavour.htm\#concept (16. 5. 2011). 


\title{
SODELOVANJE SLOVENSKE VOJSKE V MEDNARODNIH OPERACIJAH IN NA MISIJAH V LUČI ZUNANJE POLITIKE REPUBLIKE SLOVENIJE
}

\author{
PARTICIPATION OF THE SLOVENIAN ARMED \\ FORCES IN INTERNATIONAL OPERATIONS AND \\ MISSIONS IN THE LIGHT OF THE FOREIGN POLICY \\ OF THE REPUBLIC OF SLOVENIA
}

Povzetek Slovenska vojska mora biti v okviru svojih nalog sposobna izvesti vojaško obrambo države, izpolnjevati mednarodne obveznosti, sodelovati v mednarodnih operacijah in na misijah (MOM) ter v sistemu varstva pred naravnimi in drugimi nesrečami.

Odločitev države o sodelovanju v MOM je v številnih državah precej zapletena zaradi različnih in med seboj nasprotujočih si političnih pogledov ter ustavnih rešitev.

Republika Slovenija aktivno sodeluje v MOM od leta 1997. Tako želi skladno s svojimi zmožnostmi in interesi prispevati $\mathrm{k}$ vzpostavitvi mednarodnega miru in stabilnosti, predvsem v svoji soseščini, jugovzhodni Evropi.

Sodelovanje RS bo imelo v MOM predvsem funkcije varnostnih in zunanjepolitičnih interesov ter ciljev RS. SV bo zato v MOM sodelovala predvsem z višjo stopnjo tveganja, ki zahteva poudarjeno vojaško silo, in ne več predvsem z operacijami, ki so bližje policijskim nalogam.

Ključne besede

Abstract

\section{Zunanja politika, mirovne operacije in misije, Slovenska vojska.}

Within its scope of tasks, the Slovenian Armed Forces (SAF) should be capable of providing military defence of the country, fulfilling international obligations, and participating in international operations and missions (IOM) as well as in the system of protection against natural and other disasters.

In a number of countries, the decision to take part in IOMs is a rather complicated one, due to the diverse and contradictory political views and constitutional solutions. The Republic of Slovenia (RS) has actively participated in IOMs since 1997. In this way, it aims to contribute, in accordance with its capabilities and interests, to the establishment of international peace and stability, especially in its neighbourhood, the South-Eastern Europe (SEE).

Thus, in the future, the engagement of the RS in IOMs will mostly be subject to its security and foreign policy interests and objectives. The SAF participation in IOMs 
will no longer primarily include operations closer to police tasks, but rather those associated with a higher level of risk requiring enhanced military force.

\section{Key words Foreign policy, peace operations and missions, Slovenian Armed Forces.}

Introduction Due to the influence of many factors, the modern security environment is dynamic variable and marked with crisis events. Uncertainty and instability in crisis areas cause challenges, risks and threats to the operation of the international community actors. Stabilization of the situation in any crisis area requires a coordinated and integrated planning and use of the available political, civilian and military resources. The decision on the participation of national capabilities must be supported by a clearly defined exit strategy and objectives, which set out the essential functions in determining foreign policy priorities. Slovenia acknowledges the current situation and possible developments in the international political, economic and security situation in Europe and the world and builds upon the values, interests and objectives which are fundamental for the development of the Slovenian nation and the Slovenian state. Slovenia is also aware that this development can only be guaranteed in conditions of lasting peace and stability both in Europe and in the world. In international relations, Slovenia advocates a peaceful resolution of conflicts and rejects the use of force. It supports arms control, disarmament and the non-proliferation of weapons of mass destruction.

With its active participation in IOMs, the SAF aims to accomplish its development goals and fulfill its commitments in international organizations (UN, NATO, EU and OSCE). With its participation in IOMs, the SAF supports and enhances the development of national capabilities. The involvement of the SAF in IOMs also includes the provision of support to the diplomatic and civilian services in the framework of international rescue operations or interventions.

The participation of the SAF in the first IOMs was originally a political decision, which was adopted quickly, without a comprehensive expert analysis and heavily influenced by our desire to be integrated into NATO.

At the same time, the question arises whether the SAF participation in IOMs is motivated by the need of foreign policy rather than that of national security. The participation in IOMs is of particular importance for the SAF since such training enables rapid progress in the building of combat readiness, which is also important for national security. Furthermore, it is also necessary to train for individual situations in which armed forces may find themselves and which cannot be simulated in different training conditions. This article tries to answer the following questions: What is the role of the SAF in the implementation of the Slovenian foreign policy? Is the SAF a credible partner in the implementation of the Slovenian foreign policy? The article also builds on the assumption that the involvement of the SAF in IOMs requires a political consensus. 
This article presents the objectives of the Slovenian foreign policy, with the SAF as one of its operational instruments. It discusses the relationship between the Slovenian foreign policy and the SAF. It tries to establish whether Slovenia has its own national foreign policy objectives regarding the participation of the SAF in IOMs or it is simply fulfilling the objectives of international security organizations. It presents the basic strategic acts which define the participation of the SAF in IOMs.

The primary aims of this article are:

- To present the fundamental principles of the Slovenian foreign policy.

- To present and classify IOMs, with the emphasis on those operations which allow the participation of the SAF.

- To analyse the political and security reasons for engaging in those operations.

- To present the legal regulation of collective security in relation to the basic documents on IOMs in Slovenia.

- To present the contribution of the SAF to the fulfillment the obligations which arise from the membership of Slovenia in international organizations.

\section{METHODS}

In order to describe the characteristics of IOMs and Slovenian foreign policy, the article relies on the study, analysis and comparison of various domestic and foreign professional literature and command and control documents, as well as on the analysis of the decisions of the RS Government and final reports from individual peacekeeping operations. Conversations with certain persons responsible for command and control in the SAF were carried out, serving as an additional empirical research method for influencing some of my opinions and conclusions. The conclusion of the article is based on the method of research which builds upon the participation in the process of adopting decisions on the deployment of SAF soldiers in peace operations, the monitoring of the stages of preparation and conduct of activities, and the analysis after the end of participation in certain peace operation.

To some extent, my work was impeded by limited possibilities for collecting individual data on the conduct of the IOMs attended by SAF members, units and commands, since these data are marked with a certain level of classification.

\section{SLOVENIA'S FOREIGN POLICY}

The basic values of the Republic of Slovenia are enshrined in the Slovenian Constitution. Furthermore, the activities of Slovenia in the area of foreign affairs are also governed by the 2001 Foreign Affairs Act (ZZZ-1-UPB-1), Basic Constitutional Charter on the Sovereignty and Independence of the Republic of Slovenia, Declaration on the Foreign Policy of the Republic of Slovenia, Resolution on the Guidelines for National Security of the Republic of the Republic of Slovenia, the 2001 and 2010 Resolution on the National Security Strategy of the Republic of Slovenia, and 
the documents Suitable Foreign Policy and Defence Strategy of the Republic of Slovenia.

According to the Declaration on the Foreign Policy of the Republic of Slovenia (Official Gazette of the RS, No. 108/1999) (hereinafter referred to as: Declaration), the stability of South-Eastern Europe (hereinafter referred to as: SEE) is one of Slovenia's vital interests. This region also represents the very part of Europe in which Slovenia, together with its strategic partners, has to establish itself as an important international factor. Through its active role in this region, particularly in Bosnia and Herzegovina and Montenegro and in the resolution of the so-called Kosovo question, Slovenia has established itself as an important partner of NATO and the EU and, also through its participation in the UN Security Council (UNSC), proved to be a credible partner in the settlement of the situation in this part of Europe.

Due to political, security, economic and other interests and reasons, Slovenia plays an active role in SEE and therefore actively supports the efforts and initiatives of the international community for the stabilisation and development of the region. Within the Stability Pact for South-Eastern Europe, Slovenia cooperates with the EU and other members, with particular emphasis on economic projects, human rights protection, protection of minorities and in the area of humanitarian issues assistance in the mitigation of the consequences of war. Slovenia's interests include the development of its relations with both entities in Bosnia and Herzegovina (Federation and Republika Srpska), while at the same time maintaining firm support to the implementation of the Dayton Agreement. Furthermore, Slovenia continues to develop its relations with Macedonia, Albania and other countries in the region. With its active role and support to the democratic processes in the region, Slovenia is becoming an important and trustworthy partner of the international community in the settlement of the situation in this part of Europe.

Slovenian foreign policy is based on the maintenance of the Slovenian national identity and at the same time openness to the world. A successful foreign policy must represent an effective instrument for the development of the Slovenian economy and the promotion of Slovenia in the world.

According to the Declaration, given the ever increasing links between the European countries in the economic as well as security and defence areas, the strategic development and security interest of Slovenia was, at the time of the preparation of the Declaration, the accession to the EU, WEU and NATO. At that time, in order to accelerate its economic development and strengthen its international role, Slovenia aspired for active and equal participation in major international organisations and institutions. Fundamental values to be advocated by the Slovenian foreign policy certainly included a safe position in the international community. Although Slovenia was not exposed to direct security challenges, it was faced with the possibility of unpredictable security challenges in the following century. The fact is that Slovenia was situated on the outskirts of the unstable region of the Balkans and SEE and 
that its Mediterranean location also required maximum attention on the long-term strengthening of the security situation. As a new state with limited power, Slovenia had to ensure long-term security, primarily through good relations with its neighbors, integration into reliable alliances and active participation in the systems of collective security.

The international situation of that time and Slovenia's future plans therefore included its accession to NATO. In the past, the integration into the Alliance was therefore one of the fundamental strategic national interests of Slovenia and its foreign policy. In order to pursue this national interest, which was also confirmed by the decisions of the National Assembly, Slovenia, as a partner, must actively cooperate with NATO and participate in its activities and structures. In times of international stability, the security of small countries is not under threat. However, the history of the last century confirms that in periods of international crises, small countries which are not firmly rooted in strong and reliable alliances are exposed to dangerous security challenges. With its adequate foreign policy decisions and actions, Slovenia has consolidated its position as a NATO member. This means that Slovenia has demonstrated its partnership with NATO with its clear foreign policy positions, actions and activities. For improving that partnership, Slovenia's active role and participation in the efforts to reduce crisis areas in the Balkans and Afghanistan are of particular importance.

In the process of building a new European and transatlantic security structure, the EU and OSCE are also playing an increasingly important role. The accession of Slovenia to the EU, which, in addition to NATO and in cooperation with it, is becoming an important factor of the European security, also represented a strategic objective of the foreign and security policy. It took place in parallel with the accession to NATO. With its successful development and foreign policy, Slovenia has established itself as a Central European country, which has created the necessary conditions and expectations of the international community about its active involvement in the crisis area of the SEE. Based on the fundamental values and strategic interests, the priority objectives of the Slovenian foreign policy are the strengthening of its international position and reputation, good and stable relations with all the neighbouring countries, full EU and NATO membership, membership in the OECD, active role in the UN, OSCE, WTO, CEFTA and in relations with EFTA, closer cooperation with the countries of the Central Europe within CEI, in the context of trilateral cooperation (Italy, Slovenia, Hungary) and in other similar structures, active participation of Slovenia in the stabilisation of the SEE region, and the strengthening of economic cooperation. On the basis of its geographical, political, economic, cultural and historical characteristics, Slovenia's primary posture in the implementation of its foreign policy is that of the adherence to the basic principles of international law. It also demonstrates its commitment to the respect of fundamental human rights at home and abroad, and provides assistance in solving complex situations, both in its neighbourhood and elsewhere. Slovenia can only promote its national interests based on the power of arguments, relying, in a balanced way, on the alliances of states, associations and international institutions. In doing so, its guiding fundamental 
values are those of peace, security, prosperity, territorial integrity, protection and promotion of national identity. The basic principles underlying the activities of Slovenia in the area of international relations are and will always be democracy, the respect for human rights and the rule of law.

\subsection{Declaration on the Foreign Policy of the Republic of Slovenia}

The Preamble of the Declaration stipulates that the Slovenian foreign policy must advocate two fundamental values: security and prosperity of the state and its citizens, as well as the basic foreign policy interests and objectives based on a broad political consensus achieved by the parliamentary parties.

It also lays down that the primary foreign policy task of this Declaration is the normalisation of relations with the neighbouring countries based on mutual trust and respect. The Declaration emphasizes that Slovenia pursues the same objectives and principles as the EU, with a particular focus on the principle of equality. Based on the adopted Declaration, Slovenia has aligned its legislation with the legislation of the EU in order to create conditions for the free movement of goods, services, capital and people. In accordance with the objectives of the 1992 Treaty on the European Union, Slovenia wanted to participate in the process of the enlargement and deepening of the Union also on the basis of the signed European Agreement, the implementation of which, along with the negotiations and implementation of pre-accession strategy, constitutes one of the strongly interconnected parts of the process of Slovenia's integration into the EU. The Declaration also defines Slovenia's priorities within the EU and NATO, especially with regard to the increasingly strategic EU open-door policy towards other European countries in the context of the globalisation processes. Slovenia has paid special attention to that and has accordingly supported the EU Common Foreign and Security Policy, even before acquiring full EU membership (Declaration on the Foreign Policy of the RS, 1999).

\subsection{Resolution on the National Security Strategy of the Republic of Slovenia}

The Resolution on the Guidelines for National Security of the Republic of Slovenia (Official Gazette of the RS, no. 71/1993) did not provide a clear definition of Slovenia's security interests, although it was evident from its content that it defined the basic principles of national security. The amendment to the Resolution on the Guidelines for National Security of the RS (1994) provided the basis for the integration of Slovenia into European and other international economic and political structures. At the same time, Slovenia assumed both the rights and responsibilities required by those structures in the field of defence, with the exception of the provision of peacekeeping forces in the area of former Yugoslavia pending the resolution of the crisis of that time. Concurrently, the integration into NATO and the Western European Union as NATO's European pillar became Slovenia's objective for the first time. Those were the strategic principles of Slovenia which started its participation in first peace operations in 1997. 
Resolution on the National Security Strategy of the RS (Official Journal of the RS, no. 56/2001) defines Slovenia's security interest within the framework of the EU and NATO membership. In order to pursue that national interest, Slovenia must actively and comprehensively prepare for assuming the allied tasks through the Membership and Partnership for Peace Action Plan. For the first time, the SAF is clearly identified as a partner in attaining the foreign policy objectives. The Resolution also stipulates that within the system of collective defence, the defence system will perform tasks assumed by Slovenia with the accession to NATO. The SAF is responsible for military defence of Slovenia. Its main task is, in addition to deterring aggression, military defence of the state. Its other tasks include the fulfilment of obligations resulting from international treaties, participation in peace support and humanitarian operations, participation in civil protection and disaster relief in the event of natural and other disasters and the performance of other tasks defined by the law.

\subsection{Strategy of Participation of the Republic of Slovenia in International Operations and Missions}

The Strategy of Participation of the Republic of Slovenia in International Operations and Missions (Official Gazette of the RS, no. 19/10) was the first security policy and military defence document in the form of the strategy of participation in the IOM. This document consolidates the strategic and political guidelines regarding the participation in IOMs and revises them. The strategy of Slovenia's participation in international operations and missions provides a framework for decision-making on participation and defines a general set of capabilities for its implementation. The document defines the response to changes in the global environment which require a new approach, development and application of an integrated set of instruments and activities, including political, diplomatic, civilian, military, development and other instruments. In this context, particular emphasis should be given to a coordinated conduct of activities, effective coordination, consistent implementation of the policy of participation in international operations and missions, as well as the involvement of all national-level actors at all the stages of participation, from planning to implementation. In this way, Slovenia contributes to the establishment and maintenance of international peace and security, stability, democracy, humanitarian aid, establishment of the rule of law, strengthening of human rights and fundamental freedoms, development of civil society, strengthening of sustainable development in the international community and assistance in the event of natural and other disasters and thus enhances its own security. The strategy is in line with other important documents governing the field of national security, foreign policy, including development cooperation, and other strategic documents and relevant legislative acts. The strategy sets out the conditions for proper definition of strategic and implementation objectives, strengthening of analytical support in decisionmaking, greater flexibility, strengthening of coordination in order to achieve an integrated approach and synergies, achieving multiplicative effects and shortening the response time for adopting a decision on participation in a new IOM and the deployment of troops to that IOM. The strategy also sets out the legal framework for the participation of Slovenia in IOM, including the Constitution, Government 
of the Republic of Slovenia Act, Foreign Affairs Act, Defence Act, Secondment of Personnel to International Civilian Missions and International Organizations Act, Police Act, Protection Against Natural and Other Disasters Act and other legal and implementing acts. The Strategy of participation of Slovenia in international operations and missions represents a response to the changing security environment and new global challenges which are specified in more detail in the Resolution on the National Security Strategy of the RS, Foreign Policy Strategy of the RS, Public Security Strategy, Resolution on International Development Cooperation of the RS for the period until 2015 and Resolution on the National Programme of Protection against Natural and other Disasters for the Period between 2009-2015. The resulting changes require the development of a comprehensive set of mechanisms and active participation in joint efforts of the international community for the prevention, management and resolution of conflicts, post-conflict reconstruction at the global level and assistance in the event of natural and other disasters. Upon a comprehensive examination of the Strategy, my conclusion is that this document represents a link between political positions and provisions for the executive level.

\subsection{8-2012 Coalition Agreement}

In November 2008, the parties Social Democrats, Zares, Democratic Party of Pensioners of Slovenia and the Liberal Democracy of Slovenia concluded the Coalition Agreement on Cooperation in the Government of the RS for the 2008-2012 Term.

The coalition contract or agreement is not a legal act, but rather a political agreement concluded by the Government partners. It represents a political commitment of Government parties. Therefore, the sanctions in the event of a breach of contract are merely political. Since the coalition agreement is only a political commitment, there are no legal sanctions nor is the agreement examined by legal authorities.

However, I believe that it is necessary to explain the Government agreement on the IOM policy. The coalition partners made a commitment that Slovenia will participate in peace operations according to the principles of concentration and specialisation and assume obligations in operations based on UN Security Council resolutions. It will promote good practice in the performance of the role of parliamentary discussions on the deployment of units and individuals abroad and strengthen interministerial coordination in the field of deployment to IOMs. The coalition partners agreed that the Government will give priority consideration to the recall of military instructors in Iraq and the continued role of Slovenia in operations in Afghanistan. At the same time, they committed to design and prepare a clear strategy of participation of the SAF in IOMs and increase the role of the National Assembly in deploying the SAF members and other state authorities of the RS to IOMs, on the basis of broad political support of the National Assembly. 
Following the review of the Coalition Agreement, it is clear that the SAF will continue to perform its tasks abroad primarily as a result of the RS foreign policy interests, whereas the security interest plays a secondary role.

\subsection{2-2015 Coalition Agreement}

On 25 January 2012, the parties Slovenian Democratic Party, Gregor Virant's Civic List, Democratic Party of Pensioners of Slovenia, Slovenian People's Party and New Slovenia - Christian People's Party concluded the Contract for Slovenia 2012-2015, a coalition agreement on cooperation in the RS Government for the 2012-2015 term.

In Chapter 11 of this Contract, the coalition partners committed themselves to increase the effectiveness of the defence system based on internal reserves. In contrast to the past coalition agreements, the present agreement does not refer to or define the role and scope of the SAF participation in IOMs, which probably means that there will be no significant changes to the current scope of SAF participation. In accordance with the current situation, individual changes will be stipulated in the decisions of the RS Government. The present coalition agreement also makes no provision for any changes in the decision-making on participation in a specific IOM which were suggested in the previous coalition agreement.

\section{INTERNATIONAL PEACE OPERATIONS}

In the broadest sense of the world, peace operations include all forms of military and non-military activities which take place in the context of political and diplomatic efforts for the establishment and maintenance of international peace. Since the beginning of the 19 th $^{* * *}$ century, peace operations are an instrument of foreign policy. At the end of the Cold War, i.e. after 1989, they acquired new meaning. They represent one of the most visible activities of the UN, although many operations still take place outside the framework of that organisation. Peace operations therefore include all forms of military and non-military activities for the establishment and maintenance of international peace. Typically, these activities have an international mandate, usually approved by international organizations (most desirably by the UNSC). Peace operations are conducted by international organizations (such as UN), regional organizations (such as NATO, EU and OSCE) or ad hoc coalitions of states (Jelušič, 2003, pp. 20-21).

At the end of the Cold War, various threats to the world peace emerged, such as religious, economic and national conflicts in different parts of the world. In parallel, peace operations increased in number and scope as well as complexity. Standard peace operations, which were characteristic of the period of the Cold War, grew into complex, integrated operations, which include political, military and humanitarian activities.

Today, there are many different classifications of peace operations. The classification below is taken from the Joint Military Doctrine (Peace Support Operations, 1997). 
It identifies three levels with nine internationally recognized categories of military peace operations.

1. Level

Activities involving a large number of unarmed units or units armed with light weapons performing small movements.

These are:

- Observer missions.

- Separation forces.

2. Level

Conflict resolution before the crisis in individual countries between different nations and the government requires highly skilled forces and heavier weapons as on level 1. It includes the following activities:

- Preventive force deployment,

- Resolution measures in the event of internal conflicts within a state,

- Participation in provisional measures,

- Protection of humanitarian assistance,

- Provision and prohibition of movement.

3. Level

The requirement for intensive major operations with increasing threats and modern coordination of all military efforts.

These are:

- Military sanctions,

- Reestablishment of peace through the use of force,

Various levels with several types of peace interventions include:

- Ceasefire control,

- Demobilization of combatants and assistance in their integration into civil society,

- Protection f population from aggression,

- Disarmament and weapons destruction,

- Protection and escort of refugees and displaced persons,

- Humanitarian assistance,

- Building of state institutions, civilian police and legal order,

- Enforcement of human rights,

- Monitoring of free elections,

- Creation of safe zones and peaceful areas,

- Establishment and maintenance of the various prohibitions (embargo),

- Mandate compliance.

The above-mentioned peace interventions refer not only to peace operations under a UN mandate, but are also recognised and conducted by other international organizations. The diversity of the problems solved by peace operations and the possible short-term transition from one level to another make the conduct of peace operations even more difficult. Although the peace operations are increasingly 
standardised, their conduct is also made more difficult by their participants, both countries as well as individuals, since they come from backgrounds which are at different stages of social development. The greatest difficulty are unclear mandates which represent a compromise between the UNSC member states and the international community.

\subsection{Participation of countries in peace operations}

Individual countries participate in peace operations for various motives. The decision to participate in peace operations is particularly difficult for smaller countries with limited resources in all areas. However, some of the motives for the decision of individual countries to engage in peace operations (Future Place Operations Achieving Success, NATO Defence College, 1997, p. 38) can be organised in the following groups:

\section{- Political objectives}

Peace operations under the auspices of the international community can achieve results in attaining policy objectives which cannot be achieved by individual countries or can only be achieved over a long period of time. However, it should be noted that such political objectives are acceptable only if they fall under the legal system of the UN. Any other possible ambitions are nonproductive.

\section{- Country's reputation}

International peace operations, irrespective of the manner of participation, give all participants a better reputation and greater importance at an international level, which is particularly interesting and important for small countries.

\section{- Military training and experience}

Peace operations create direct, excellent conditions for military units in a wide range of military and humanitarian situations. Such training enables rapid progress in establishing combat readiness, which is also important for national security. In fact, certain situations or circumstances in which armed forces may find themselves cannot be simulated in different conditions of training.

\section{- Financial savings}

Although peace operations are very expensive, when the crises develop into full-out conflicts, the costs of peace operations are still lower than the costs of individual countries. This is especially true for small countries. The UN introduces specific standards for the costs of individual operations and, certainly, the share of the costs for a soldier of an individual country with respect to the working conditions is lower than otherwise.

\subsection{Classification of peace operations}

The classification or basic categorisation of peace operations reveals the complexity and diversity of the tasks facing the international community in the conduct of IOMs. 
Different classifications among organisers (Peace Support Operations, 1997, p. 18) and the emergence of new operations (Future Place Operations Achieving Success, NATO Defence College, 1997, p 33) show that the tasks defined for such operations are difficult to distinguish. They mostly differ a lot from the traditional military tasks and are more similar to police tasks. Nevertheless, they can rapidly escalate into demanding military operations of limited duration and a high degree of dynamics. In principle, however, every classification, regardless of the organizer, shows that these operations are, on the one hand, of peacekeeping nature, and on the other hand, they represent peace enforcement operations. In addition, there are also preventive diplomacy, peacemaking and peacebuilding operations (Jelušič, 2003, p. 20).

Up until now, the SAF only participated in peacekeeping operations. However, due to the active involvement of Slovenia in international structures and due the level of qualification, equipment and experience of the SAF members demonstrated in all peacekeeping operations in which they participated, involvement in other forms of peace operations mentioned above can be expected.

\section{REGULATORY FRAMEWORK OF COLLECTIVE SECURITY}

Since its establishment, the UN has been the leading organizer of peace operations. Although today, peacekeeping operations are most commonly associated with the $\mathrm{UN}$, this method of conflict settlement and peace enforcement is not mentioned in the UN Charter, the organisation's basic foundational document. Upon the establishment of the UN, the five major forces called permanent members of the Security Council were assigned the leading role in the maintenance of international peace and security. Chapter 6 of the UN Charter, Articles 33 to 38, provides for the mechanisms for a pacific settlement of disputes, such as negotiation, enquiry, mediation, conciliation, judicial settlement and other peaceful means chosen by the parties to the dispute. These are diplomatic and legal means. Chapter 7 of the UN Charter, Articles 39 to 51, provides for actions with respect to possible threats to peace, breaches of peace and acts of aggression. These measures refer to sanctions and coercive actions. Peacekeeping operations do not fall within any of the above-mentioned categories. Therefore, some experts rank them between Chapters 6 and 7, or even believe that they should be specified in the so-called chapter 6.5 of the UN Charter. Such chapter does not exist. However, peacekeeping activities can be ranked somewhere between, on the one hand, means of conflict resolution which are of diplomatic and legal, but purely non-military and non-violent nature, and on the other hand, military violent means of resolving international conflicts (Jelušič, 2003, p. 22).

Peacekeeping operations, as developed since 1947, especially during the Cold War, demonstrate the inability of the UNSC to establish, on the basis of the consensus of all the permanent members, the standard peace enforcement operations, as defined in Chapter 7 of the UN Charter. 
The preparation and conduct of peace operations involving the armed forces of different countries also require a series of documents which set out the powers and responsibilities of all the participants. The documents have a very different importance, structure and contents, depending on the factors related to individual operations. Some important basic documents have been developed for the conduct of peacekeeping operations, which, by nature, are high-level political, military and humanitarian international activities The below documents are listed by the UN. However, they are also used, fully or at least in part, by other organizations which carry out peace operations. These documents are (Peace Support Operations, 1997):

- UN Mandate,

- Memorandum of Understanding on the Participation of Forces (MOU),

- Status of Forces Agreement (SOFA),

- Convention on the Safety of the United Nations and Associated Personnel (1994),

- Deployment Conditions,

- Rules of Engagement (ROE),

- Transit Agreement (TA),

- Others.

\section{LEGAL ASPECTS OF PARTICIPATION OF THE REPUBLIC OF SLOVENIA IN IOMs}

The Ministry of Foreign Affairs is responsible for the process of coordination and examines the initiative for the participation of Slovenia in international operations and missions. The Secretariat of the National Security Council supplements the initiative with risk assessment and forms an opinion. The coordinated and amended proposal is examined by the Ministry of Foreign Affairs, Ministry of Defence and Ministry of the Interior at the ministerial level or the level of secretaries of state. The proposal contains a justification, including a clear participation objective and a legitimate international mandate, the assessment of the most appropriate range of mechanisms, activities and necessary resources, definition of expected effects, intelligence and information as well as intelligence and security support, and the assessment of security risks. The Ministry of Foreign Affairs and the responsible ministry submit the coordinated and amended proposal to the RS Government for decision.

The current legal bases in Slovenia governing the area of participation of the SAF members in peace operations are:

- UN Charter and Security Council Resolution,

- Constitution of the Republic of Slovenia,

- Defence Act,

- Service in the Slovenian Armed Forces Act,

- Foreign Affairs Act,

- Military Doctrine,

- Strategy of Participation of the Republic of Slovenia in International Operations and Missions, 
- RS Government decision on the deployment of SAF units to the peace operation (adopted separately for each operation),

- International treaties and other implementing acts (adopted separately for each operation),

- Decree of the Minister of Defence on the deployment of SAF members to the IOMs, made on the basis of the decision adopted by the RS Government,

- Regulations and rules governing the labour status of members in the performance of tasks abroad,

- Unit formation table.

As a member of the United Nations, Slovenia has actively participated in peace support campaigns on the basis of decisions of this organisation's General Assembly or Security Council and will also participate in the future, if necessary, in accordance with its capabilities. Pursuant to the UN Charter provisions (Chapter 7 ), the UNSC adopts a decision on the implementation of measures against a certain country, including the use of force. On the basis of a UNSC resolution and in application of Article 84 of the Defence Act, the RS Government adopts a decision on the participation of the SAF in the implementation of those measures.

Pursuant to paragraph 3 of Article 84 of the Defence Act (Official Gazette of the RS, no. 103/2004 - ZOBr - UPB-1), the RS Government adopts a decision on the participation of the SAF in the fulfilment of commitments made in international organizations, in accordance with international treaties. In the case of the UN, the UN Charter should be regarded as an international treaty which also commits the RS. Pursuant to the provisions of the Charter governing the powers of the SC, particularly Chapter 7, the SC resolution which addresses the use of force against a certain country, clearly represents an obligation referred to in Article 84 of the Defence Act and paragraph 5 of Article 75 of the Foreign Affairs Act. Specific arrangements on participation, if necessary, would be ratified by the RS Government on the basis of paragraph 5 of Article 75 of the Foreign Affairs Act.

Article 8 of the Slovenian Constitution specifies that laws and other regulations must be consistent with the generally accepted principles of international law and international treaties which are binding for Slovenia. Ratified and published treaties can be applied directly. Formal participation requirements*** are specified in the Defence Act, particularly the amended Act which entered into force on 13 June 2002. Given the fact that the international treaty is referred to several times in the Defence Act, the process of preparation of international participation needs to take into account the provisions of the Foreign Affairs Act (Chapter 5).

The power of decision to employ the SAF based on the Defence Act is divided between the RS National Assembly and the RS Government. In exceptional cases, the President of the Republic also has such power. Chapter 5 of the Foreign Affairs Act (Official Gazette of the RS, no. 45/01) defines the conclusion of treaties, explicitly enabling or facilitating the process of ratification of those international 
treaties in the field of defence which represent the fulfillment of the commitments or decisions on international participation of the RS (Article 75). It also identifies international acts other than treaties (minutes, participation programmes, etc.) which, due to the implementation of international treaties, are concluded by joint bodies established on the basis of these treaties and pursuant to which the signatories do not assume new legal obligations. The Government is only informed about these acts. The information is communicated to the Government, which authorizes a proposed person to carry out the signature.

The SAF participation in peace operations is subject to the following three conditions:

- Security Council Resolution and mandate,

- International treaty, fulfilment of obligations in international organisations,

- Implementing acts (Memorandum of Understanding on Participation, Technical Agreement).

In the event of the existence of a Security Council resolution, the decision on the employment of the SAF is adopted by the RS Government on the basis of Article 84 of the Defence Act. The corresponding agreement is ratified by the Government. However, a provisional application of the agreement as of the date of signature based on the Foreign Affairs Act is also possible.

In addition to these basic international and national documents which represent the basis for the preparation and successful conduct of peace operations, individual countries must adopt several normative acts which enable a proper and rapid involvement in peace operations. In 2009, the RS Government adopted the Strategy of Participation of RS in IOMs, which provides a comprehensive approach of the RS in the area of IOMs.

On the basis of the above-mentioned act, the SAF General Staff prepared a directive on the planning and preparation of SAF capabilities for participation in IOMs. The directive defines the processes, procedures and planning at the strategic and operational levels for the participation of the SAF in IOMs. It also provides for the unity of planning, organisation and preparation as well as effective command and control during the SAF participation in IOMs.

The aims of the directive are as follows:

- Definition of the method of planning and preparation of SAF capabilities for participation in IOMs.

- Identification of the ways of representing the interests of the SAF in the military field in the international environment or operations in which the SAF would participate or is already participating.

- Establishment of an effective method of work and cooperation with the MoD authorities to achieve a concerted representation of national interests and the interests of the SAF in the international environment. 
- Provision of the necessary information to the SAF missions abroad, so that they are able to operate actively and effectively in accordance with national objectives, policies and obligations.

- Establishment of the processes for effective cooperation between the General Staff of the SAF (SAF GS), Military Schools Centre (MSC) and SAF units.

- Effective exchange and processing of information and documents.

\section{SAF PARTICIPATION IN PEACE OPERATIONS}

\subsection{Purpose of the SAF}

The RS Constitution does not clearly identify the purpose of the SAF. The purpose of the armed forces can be inferred from: Article 4 of the Constitution, which refers to the "territorially unified and indivisible state"; Article 5, which stipulates that "the state shall create opportunities for the harmonious development of society and culture in Slovenia"; and Article 124, which states that "the nature, extent and organization of defence, inviolability and integrity of the national territory is governed by the law adopted by the National Assembly with a two-thirds majority vote of the present Members of Parliament." Article 124 also stipulates that "in ensuring security, the state primarily builds on the policy of peace and culture of peace and non-violence."

Article 2 of the Defence Act refers to the purpose of defence and stipulates that "the fundamental purpose of defence is to deter attacks on the country and to defend the independence, inviolability and integrity of the state." Article 2 also stipulates that "this purpose is further fulfilled through the integration and active participation in international security alliances in accordance with international treaties".

This means that the purpose of defence, and thus also of the SAF, is to ensure the sovereignty and independence of the RS through the defence of its territorial inviolability and integrity, which is provided through the prevention of and defence against any kind of aggression, military contribution to international peace and stability, and the involvement of the armed forces in ensuring the safety and welfare of the citizens. ${ }^{1}$

\subsection{Tasks of the SAF}

The SAF tasks defined in the Defence Act are as follows:

- To provide military education and training in armed combat and other forms of military defence.

- To ensure the necessary or required readiness.

- To perform military defence in the event of an attack on the state.

${ }^{I}$ The proposed amendment of the definition of the purpose specifies more in detail the fundamental tasks of the SAF in performing the standard defence of the state, its international role and its support to other state authorities which operate either in the field of civil protection and disaster relief or in the field of assistance to other state authorities, such as the Police or Coast Guard. 
- To participate in protection and rescue activities in the event of natural and other disasters in line with its organisation and equipment level.

- To fulfill obligations assumed by the state in international organisations and in accordance with international treaties.

- To cooperate with the Police in the wider protection of the national border within the national territory in accordance with the plans and upon a preliminary decision of the Government. During the performance of these tasks, the SAF members do not have police powers.

In relation to the Defence Act, the Service in the Slovenian Armed Forces Act does not add any new tasks. However, Article 22 defines in more detail what constitutes the fulfilment of commitments assumed by the state in international organizations and in accordance with international treaties.

The SAF fulfils these obligations by:

- Military diplomacy activities.

- Participation in operations, missions and other activities aimed at the prevention of conflict, maintenance and enforcement of peace and collective defence.

- Participation and conduct of activities in joint commands and units of the Alliance and other international organizations.

- Participation and conduct of activities in bodies, representations or services of international organizations.

- Participation and conduct of activities in joint commands and units, established together with other countries.

- Provision of military assistance of various forms, such as armament and military equipment.

- Provision of humanitarian assistance or assistance for the conduct of humanitarian operations.

- Participation in activities for the prevention of terrorism and other phenomena endangering stability and security.

\subsection{Participation of the SAF units and members in IOMs}

Since 1997, Slovenia actively participates in peace operations abroad with its military units. Thus, it attempts to contribute to the establishment of peace and stability in the world, in particular in its neighbourhood and the SEE, in accordance with its abilities and interests. The causes or reasons that led to the participation of Slovenia and consequently the SAF in peace operations are as follows (Prezelj, 2003):

- Stage of development of the SAF.

- Syndrome of running away from the Balkans.

- The process of moving closer to joining international structures, especially NATO.

- Evolvement of national interest.

Based on the experience of the first instances of participation of the SAF members in peace operations abroad, my conclusion is that the involvement in the first peace operations was primarily a political decision, which was made quickly, without a 
comprehensive professional analysis, and was heavily influenced by the desire of Slovenia to be integrated into NATO. The political decision was followed by very intense preparations within the MoD and SAF. However, they were not supported in terms of material, financial and human resources. The political decision at the state level was not followed by support in terms of material and human resources, additional financial resources, additional employment, comprehensive legal regulation, etc. The participation in first peace operations was in fact a huge challenge in terms of organization, finances and operation.

At the same time, the question arises whether the SAF participation in peace operations is motivated by the need of foreign policy rather than that of national security. Participation in peace operations is of particular importance for the SAF, since such training enables rapid progress in the building of combat readiness, which is also important for national security. It is also necessary to train for individual situations in which armed forces may find themselves and which cannot be simulated in different training conditions. For the SAF, the development of which was based on the territorial defence doctrine, as well as for the state, participation in operations abroad was a completely new task and a new challenge. Although in the former state of Yugoslavia, some soldiers of Slovenian nationality participated in peace operations abroad, there was no systematic experience. However, it is also true that these people were not actively involved in the preparation of the first peace operations of the SAF.

Given the fact that participation in peace operations has become an entirely new category of its operation, the SAF has tried to gradually create a system of collecting and analysing the experience acquired by SAF members who participated in a certain operation. Nevertheless, up until now, these efforts have only been partially successful. For this reason, questions of organizational and substantive nature that have already been resolved but not recorded and archived continue to arise.

\subsection{Overview of participation of the SAF in IOMs}

In the thirteen years of participation of the SAF in IOMs (Furlan, Jazbec, 2009), its members have been involved in nineteen IOMs on three continents. Based on the decisions of the RS Government, the SAF has steadily increased its contribution in crisis areas. Slovenia's participation peaked in 2007, when it deployed an entire battalion (the SOKOL battle group), took over the area of responsibility and became directly involved in the KFOR system of command and control.

In October 2012, 430 SAF members were involved in IOMs in nine missions.

According to the available data, 7580 SAF members and MoD employees have participated in IOMs so far (PSSV, May 2012). 
In addition to SAF members, members of the Police and civilian functional specialists (CFS) are also involved in IOMs.

In 1997, members of the Police started to participate in peace missions in the framework of the defence organization of the Western European Union within the MAPE mission in Albania. Currently, 21 police officers participate in five missions. So far, the total number of police officers who have participated is 287 . Every year, up to 30 police officers are involved in 14 different peace missions (http://www. policija.si/index.php/mednarodno-sodelovanje/mednarodne-civilne-misije).

Since 2007, 18 CFS have been deployed, with the total of 20 CFS deployments (http:// www.mo.gov.si/fileadmin/mo.gov.si/pageuploads/revija_sv/2012/sv12_07.pdf).

The overview of the participation of the SAF in IOMs so far includes, in particular, the overview of decisions of the RS Government and responses of the public to their adoption. Until 2006, Slovenian public as well as politics supported the participation of the SAF in IOMs.

The first major controversies and expert discussions began on 12 January 2006, when the Government decided that, in the context of the NATO mission to train Iraqi security forces in Iraq, Slovenia would deploy four members, including three NCOs and an officer.

Later on, the focus of controversies, involving both the political elites as well as the expert public, became the peace operation and mission ISAF in Afghanistan, where the SAF has participated since February 2004. The discussion on the SAF participation in Afghanistan was most intense upon the decision on the deployment of SAF members in ISAF, as part of its Operational Mentor and Liaison Team (OMLT). The Government adopted the decision on the basis of expert consultations at home and, in particular, in the framework of NATO. The common objective of all political discussions was the suspension of SAF participation in the ISAF operation and the withdrawal of units from the troubled area. The Government adopted a decision, according to which the SAF would participate in the OMLT up to 2012. In 2011, it would also examine the possibilities of continuation or completion of the operation. In 2012, a decision was adopted, according to which the SAF would withdraw from IOMs in 2014, when the entire international operation ISAF would come to an end.

In parallel with this initiative, there was also an initiative on the enhanced role of the RS National Assembly in adopting decisions on new IOMs or major changes, either the increase or decrease in the number of members as well as any possible changes in the mandate of an individual IOM. Thus, this kind of political and operational decisions would gain a wide political support. However, the new Coalition Agreement 2012-2015 contains no reference to these changes. 
In the study Slovenian Public Opinion 2005, 2007 and 2009, the question "To which regions of the world should Slovenia send its military and Police forces to conduct peace operations?" received the following answers:

\begin{tabular}{|r|l|r|r|c|}
\hline & The area of IOMs where the SAF is present & SJM05 $_{2}$ & SJM07 $_{1}$ & SJM09 $_{2}$ \\
\hline 1 & States on the territory of the former Yugoslavia & 39.7 & 35.0 & 36.7 \\
\hline 2 & Afghanistan & 10.1 & 8.7 & 10.9 \\
\hline 3 & African states (for example Chad, Sudan) & 13.5 & 10.4 & 12.2 \\
\hline 4 & $\begin{array}{l}\text { Middle East (for example Lebanon, Palestinian territories - the West } \\
\text { Bank, the Gaza Strip) }\end{array}$ & 11.2 & 6.8 & 11.0 \\
\hline 5 & I don't know, no answer & 53.5 & 61.6 & 57.2 \\
\hline
\end{tabular}

Source: Malešič, Marjan, Malnar, Brina, Toš, Niko at al. Slovensko javno mnenje 2009/2: Raziskava o nacionalni in mednarodni varnosti [datoteka podatkov]. RS, Ljubljana: Fakulteta za družbene vede, Center za raziskovanje javnega mnenja in množičnih komunikacij [izdelava], 2009. RS, Ljubljana: Univerza v Ljubljani, Arhiv družboslovnih podatkov [distribucija], 2010.

The results show public support to individual IOMs depending on the area of operation. Comparison of the above-mentioned controversies with ISAF is not possible, since the study was conducted in 2009 , before the adoption of the decision concerning the deployment to OMLT. However, a very low public support to the SAF operations in Afghanistan can be observed.

Conclusion The Republic of Slovenia adopts decisions on participation in IOMs and implements these decisions in accordance with the applicable legal framework, including the Constitution, Government of the Republic of Slovenia Act, Foreign Affairs Act, Defence Act, Secondment of Personnel to International Civilian Missions and International Organizations Act, Police Act, Protection Against Natural and Other Disasters Act and other important legal and implementing acts.

The SAF participates in IOMs exclusively on the basis of UN Security Council Resolutions and in accordance with the UN Charter and the EU Common Foreign and Security Policy, taking into account the strategic concept of NATO and the goals of the OSCE and Council of Europe. Participation of Slovenian military capabilities in international operations and missions follows the principle of a uniform pool of forces as well as focused and concentrated involvement in conflict areas, taking into account a comprehensive national approach and use of national advantages. Participation is planned in accordance with the principle of moderate geographical dispersion and greater specialization in the provision of certain niche capabilities.

The SAF participation in all kinds of IOMs, except in international rescue operations, is planned in accordance with the order of priority set out in the Strategy of Participation of the Republic of Slovenia in International Operations and Missions. 
This article confirms the assumption that the SAF is a suitable partner for the implementation of the Slovenian foreign policy through its participation in the UN peace forces and NATO multinational forces for peace operations (under the mandate of the UN), and to provide active assistance in the maintenance and preservation of international peace and security. Furthermore, since 1997, the SAF units have actively participated in peace operations and successfully performed all the tasks assigned to them by the RS Government decisions on the involvement in peace operations.

In the future, the involvement of Slovenia in international operations will primarily be aimed at pursuing the interests of Slovenia in the field of security and foreign policy. The SAF will therefore be primarily involved in international operations with a high degree of risk requiring an emphasized military component, rather than primarily in operations that are closer to police duties, as was confirmed during the review of the coalition agreement. At the same time, it is clear that the SAF has performed and will continue to perform their tasks abroad primarily as a result of the RS foreign policy interests, which are most often connected to security interest. As a policy instrument, the SAF must attain its foreign policy objectives also when it comes to participation in IOMs. It should be noted that both the interest of foreign policy as well as the security interest are strongly associated with NATO and the EU and the resulting obligations to provide collective defence and collective security.

The thesis which states that the involvement of the SAF in international operations requires political consensus can only be partially confirmed, since the participation of the SAF in IOMs has become the subject of political controversies as well as public discussion. The controversies started with the Government decision on the deployment of four SAF members in the context of the NATO mission to train Iraqi security forces in Iraq, continued with the participation of the SAF forces in Afghanistan, and culminated after the decision on the deployment of OMLT to ISAF14 in 2010.

This article also defends the position that only highly trained and motivated units can participate in peace operations. Up until now, this condition has been successfully fulfilled by the SAF. This position is supported by the fact that to this day, peace operations have not yet demanded any victims either in accidents or in combat

1. Direktiva o organiziranju in delovanju predstavništev in predstavnikov SV v tujini, 2009. Ljubljana: $G \dot{S} S V$.

2. Direktiva za načrtovanje in pripravo zmogljivosti Slovenske vojske za sodelovanje v mednarodnih operacijah in misijah, 2010. Ljubljana: GŠSV.

3. Furlan, B. et al, 2006. Vojaška doktrina. Ljubljana: PDRIU.

4. Future Place Operations Acheving Success, 1997. Rim: NATO Defence College.

5. Grizold, A., 1999. Evropska varnost. Ljubljana: FDV.

6. Grizold, A., Ferfila, B., 2000. Varnostne politike velesil. Ljubljana: FDV.

7. Jazbec, M. et al, 2002. Primerna zunanja politika. Ljubljana: MZZ, center za raziskave.

8. Jelušič, L., 2003. Mirovne operacije, I. del. Ljubljana: MO RS/Revija SV.

9. Jelušič, L., ur., 2005. Mirovne operacije in vloga Slovenije. Ljubljana: FDV. 
10. Obrambna strategija RS, Vlada RS, št. 820-00/2001-1, z dne 20. 12. 2001.

11. Peace Spport Oerations, 1997, Joint Military Doctrine.

12. Podbregar, I., 2000. Interoperabilnost kadrov manjših držav v mirovnih operacijah. Ljubljana: FOV: doktorska disertacija.

13. Podbrežnik, B., 2003. Sodelovanje Slovenske vojske v mirovnih operacijah v obdobju med leti 1997 in 2002. Ljubljana: FDV, diplomska naloga.

14. Pravila službe v SV, Uradni list RS, št. 84/09.

15. Prezelj, I., 2003. Mednarodne operacije za podporo miru. Gornja Radgona: razprava na posvetu.

16. Resolucija o izhodiščih zasnove nacionalne varnosti RS, Uradni list RS, št. 71/93 in 2/94.

17. Resolucija o splošnem dolgoročnem programu razvoja in opremljanja Slovenske vojske do leta 2025 (ReSDPROSV 2025), Uradni list RS, št. 99/10.

18. Resolucija o strategiji nacionalne varnosti RS, Uradni list RS, št. 56/01.

19. Resolucija o strategiji nacionalne varnosti RS, Uradni list RS, št. 27/10.

20. SKUPINA AVTORJEV, 1993. International Military and Defence Encyclopedia. Washington: Brassey's (US).

21. Strategija sodelovanja Republike Slovenije v mednarodnih operacijah in misijah, Uradni list RS, št. 19/10.

22. UN Military Observers Handbook, 1994, United Nations.

23. Ustava RS, Uradni list RS, št. 33/91 s spremembami in dopolnitvami.

24. Ustanovna listina Združenih narodov in Statut meddržavnega sodišča, 1977, New York: Urad za javne informacije (ZN).

25. Zakon o obrambi. Ustava RS, Uradni list RS, št. 82/94 s spremembami in dopolnitvami.

26. Zakon o službi v Slovenski vojski (ZSSloV). Uradni list RS, št. 68/2007, 58/08.

27. Zakon o zunanjih zadevah. Uradni list RS, št. 45/01, s spremembami in dopolnitvami.

28. http://www.gov.si/vrs/ (7. 5. 2012).

29. http://www.mo-rs.si/ (7. 5. 2012).

30. http://www.mors.si/fileadmin/mors/pdf/publikacije/zbornik_f.pdf. (10. 4. 2012-7. 5. 2012).

31. http://www.policija.si/ (10. 11. 2010-10. 12. 2010).

32. http://www.slovenskavojska.si/fileadmin/slovenska_vojska/pdf/bilten_sv/bilten_sv_12_3. $p d f(10.4$. 2012-7. 5. 2012).

33. http://www.slovenskavojska.si/fileadmin/slovenska_vojska/pdf/bilten_sv/bilten_sv09_11_1. $p d f(10.4$. 2012-7. 5. 2012). 
Avtorji

Authors 


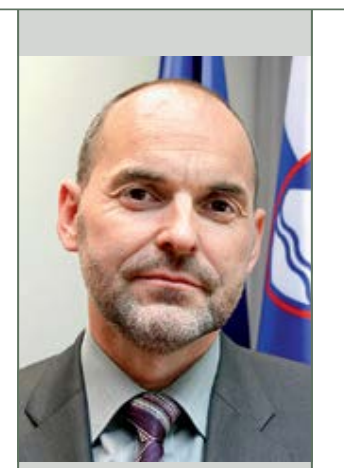

Dr. Igor Kotnik je doktoriral (2000) na Katedri za obramboslovje. Vojaško znanje in izkušnje je pridobival kot slušatelj in inštruktor v ŠROP Bileća (1985-1986), poveljnik voda v TO (1987-1991) ter rezervni štabni častnik v 24. OKMB (1992-2000). Od leta 2000 je bil svetovalec treh ministrov za obrambo, koordinator obrambnih priprav na Ministrstvu za zdravje ter namestnik generalnega direktorja za obrambno politiko MO. V letih 2010-2011 je končal RCDS v Londonu. Od leta 2012 je svetovalec NGŠSV, vmes (2014-2015) je bil POLAD poveljnika Natovega poveljstva v Sarajevu.

Igor Kotnik, PhD, obtained his PhD (2000) in Defence Studies from the University of Ljubljana. He acquired military knowledge and experience as a cadet and instructor in Infantry Reserve Officer School in Bileća (1985-1986), platoon commander in the Territorial Defence (1987-1991) and reserve staff officer in the $24^{\text {th }}$ Armoured Mechanised Battalion (1992-2000). Since 2000, he has been appointed advisor to three Ministers of Defence, coordinator of Crisis management at Ministry of Health, and Deputy Director of the Defence Policy Directorate at MoD. In 2010-2011, he graduated from RCDS, London. Since 2012, he has been working as POLAD to Chief of the SAF General Staff with an interim deployment as POLAD COM NATO HQ Sarajevo in 2014-2015.

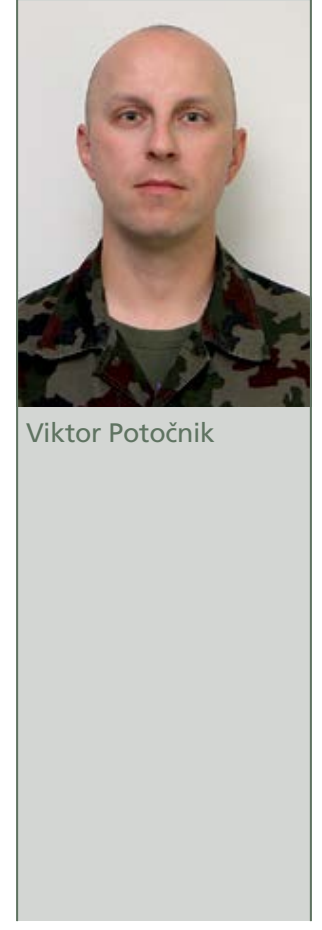

Major mag. Viktor Potočnik je v SV zaposlen od leta 2001. Opravljal je dolžnosti poveljnika motoriziranega voda, poveljnika minometne čete in motorizirane čete $\mathrm{v}$ MOM ter načelnika S-3 pehotne brigade SV. Udeležil se je treh MOM, opravil je več izobraževanj in usposabljanj v tujini, predvsem S področja ognjene podpore. Leta 2011 je končal Višje štabno šolanje na CGSC v bazi Fort Leavenworth v ZDA in pridobil naziv Master of Military Arts and Science. Zdaj dela v J-5 v Ğ̌SS.

Major Viktor Potočnik, MsC, has worked in the SAF since 2001. So far, he has performed duties of a Motorised Platoon Commander, Mortar Company and Motorised Company Commander in international operations and missions, and Chief, S-3 in SAF Infantry Brigade. He has been deployed to three operations and missions, and has attended several education and training programmes abroad, mainly in the field of fire support. In 2011, he completed Senior Staff Course and CGSC, Fort Leavenworth, USA and obtained the title Master of Military Arts and Science. Currently, he works in J-5 at SAF General Staff. 


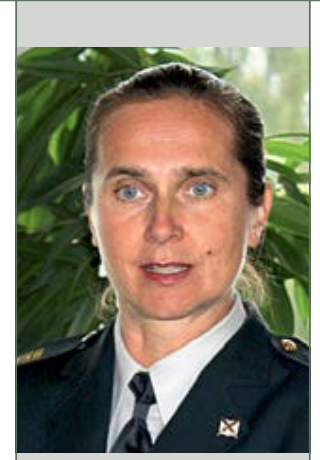

Mojca Pešec

Polkovnica dr. Mojca Pešec je doktorica obramboslovja. Julija 2013 je prevzela dolžnost vodje nacionalnega predstavništva za povezave pri Natovem poveljstvu za transformacijo v ZDA. Njeno strokovno delo obsega številne članke. Je soavtorica več strateških dokumentov Slovenske vojske in strokovnih člankov, ki jih je objavila med službovanjem $\mathrm{v}$ Natovem poveljstvu za transformacijo (ACT). Za izjemne dosežke in oseben prispevek pri Natovih aktivnostih je dobila NATO Meritorious Service Medal.

Colonel Mojca Pešec, PhD, holds a PhD in Defence Studies. In July 2013, she asumed the duty of National Liaison representative with Allied Command Transformation (ACT). She has authored numerous articles and co-authored several SAF strategic documents and professional articles published during her term at ACT Norfolk. She has been awarded NATO Meritorious Service Medal for her exceptional service and personal contribution to NATO activities.

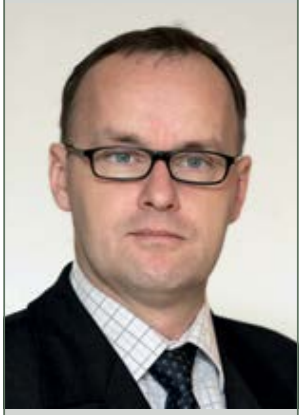

Uroš Krek

Mag. Uroš Krek je svetovalec predsednika republike za obrambo in namestnik generalne sekretarke Urada predsednika republike. Bil je generalni sekretar urada predsednika, državni sekretar na Ministrstvu za obrambo, opravljal je funkcije v. d. generalnega direktorja Direktorata za obrambno politiko, direktorja Urada za obrambno politiko, koordinatorja za članstvo v Natu ter direktorja Uprave za oborožitev in Uprave za razvoj. Je udeleženec osamosvojitvene vojne in ima čin podpolkovnika. Leta 2001 je magistriral na Univerzi za nacionalno obrambo v ZDA in je predavatelj vojaške strategije na generalštabnem šolanju.

Uroš Krek, MSc, is Adviser to the President of the Republic of Slovenia on Defence Issues and Deputy Secretary-General at his office. Before that, he was Secretary-General at the President's office and State Secretary at the Ministry of Defence, where he also worked as Acting Director General of the Defence Policy Directorate, NATO Membership Coordinator and Director of the Armament Administration and Development Administration. He participated in the War for Slovenia and carries the rank of Lieutenant Colonel. In 2001, he obtained his master's degree at NDU, USA. He teaches military strategy in the SAF general staff course. 


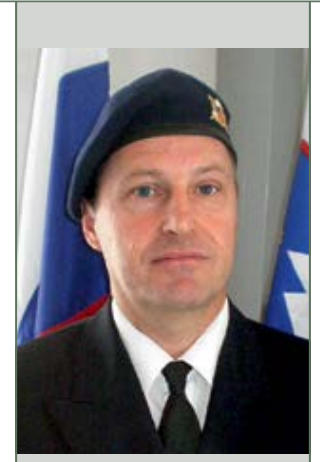

Ivan Žnidar

Kapitan fregate Ivan Žnidar je univerzitetni diplomirani vojaški pomorski častnik. V Slovenski vojski je opravljal različne poveljniške, štabne in strokovne dolžnosti na področju pomorstva, med drugim je bil poveljnik 430. mornariškega diviziona in načelnik oddelka za pomorstvo na GŠSV. Je udeleženec mirovne misije na Kosovu. Sodeloval je v številnih projektih razvoja opreme, plovil, učnih programov in vojaškostrokovne literature na področju pomorstva. Leta 2011 je končal generalštabno šolanje. Zdaj opravlja dolžnost poveljnika Verifikacijskega centra.

Commander Ivan Žnidar graduated from Naval Academy. He has performed several commanding, staff and professional duties in the Slovenian Armed Forces, including Commander, $430^{\text {th }}$ Naval Division and Chief of Naval Section at the SAF General Staff. He was deployed to the peacekeeping mission in Kosovo once. He has worked in various project teams for the development of naval equipment, vessels, curricula and professional naval documents. In 2011, he completed general staff course. Currently, he works as Commander of the SAF Verification Centre.

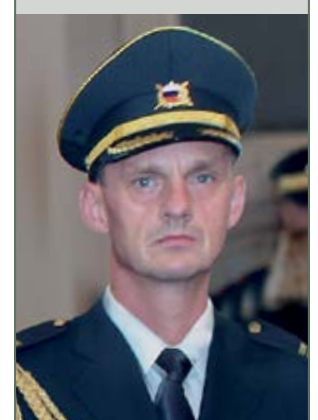

Branko Podbrežnik

Polkovnik Branko Podbrežnik je univerzitetni diplomirani politolog, smer obramboslovje. Na Ministrstvu za obrambo in v Slovenski vojski je zaposlen od leta 1991. Opravljal je strokovne, vodstvene in poveljniške dolžnosti. Izobraževal se je pretežno doma, med drugim je opravil šolo za rezervne oficirje v Bileći, višji štabni tečaj ter leta 2011 končal generalštabno šolanje. Zdaj opravlja naloge načelnika Kabineta načelnika GŠSV.

Colonel Branko Podbrežnik graduated in political sciences defence studies. In 1991, he joined the Ministry of Defence and the Slovenian Armed Forces, and has since then performed several professional, leadership and commanding duties. He completed most of his education and training in Slovenia. Among other programmes, he finished the Reserve Officer School in Bileća and the General Staff Programme (2011). He is currently Head of the Chief of the General Staff's Office. 


\section{Navodila avtorjem za oblikovanje prispevkov Instructions for the authors of papers}




\section{NAVODILA AVTORJEM ZA OBLIKOVANJE PRISPEVKOV ZA SODOBNE VOJAŠKE IZZIVE IN VOJAŠKOŠOLSKI ZBORNIK}

\section{Vsebinska navodila}

Splošno

Sodobni vojaški izzivi je interdisciplinarna znanstveno-strokovna publikacija, ki objavlja prispevke o aktualnih temah, raziskavah, znanstvenih in strokovnih razpravah, tehničnih ali družboslovnih analizah z varnostnega, obrambnega in vojaškega področja.

Vojaškošolski zbornik je vojaškostrokovna in informativna publikacija, namenjena izobraževanju in obveščanju o dosežkih ter izkušnjah na področju vojaškega izobraževanja, usposabljanja in izpopolnjevanja.

Kaj objavljamo?

Objavljamo prispevke v slovenskem jeziku s povzetki, prevedenimi v angleški jezik, in po odločitvi uredniškega odbora prispevke v angleškem jeziku s povzetki, prevedenimi v slovenski jezik.

Objavljamo prispevke, ki še niso bili objavljeni ali poslani v objavo drugi reviji. Pisec je odgovoren za vse morebitne kršitve avtorskih pravic. Če je bil prispevek že natisnjen drugje, poslan v objavo ali predstavljen na strokovni konferenci, naj to avtor sporočiti uredniku in pridobiti soglasje založnika (če je treba) ter navesti razloge za ponovno objavo.

\section{Tehnična navodila}

Omejitve dolžine prispevkov

Recenzije
Prispevki naj obsegajo 16 strani oziroma 30.000 znakov s presledki (avtorska pola), izjemoma najmanj 8 strani oziroma 15.000 znakov ali največ 24 strani oziroma 45.000 znakov.

Prispevki se recenzirajo. Recenzija je anonimna. Glede na oceno recenzentov uredniški odbor ali urednik prispevek sprejme, če je treba, zahteva popravke ali ga zavrne. Pripombe recenzentov avtor vnese v prispevek.

Zaradi anonimnega recenzentskega postopka je treba prvo stran in vsebino oblikovati tako, da identiteta avtorja ni prepoznavna.

Avtor ob naslovu prispevka napiše, v katero kategorijo po njegovem mnenju in glede na klasifikacijo v COBISS spada njegov prispevek. Klasifikacija je dostopna na spletni strani revije in pri odgovornem uredniku. Končno klasifikacijo določi uredniški odbor. 
Lektoriranje Lektoriranje besedil zagotavlja OE, pristojna za založniško dejavnost. Lektorirana besedila se avtorizirajo.

Prevajanje Prevajanje besedil ali povzetkov zagotavlja OE, pristojna za prevajalsko dejavnost oziroma Šola za tuje jezike Centra vojaških šol.

Navajanje Navajanje avtorjev je skrajno zgoraj, levo poravnano.

avtorjev Primer:

prispevka Ime 1 Priimek 1,

Ime 2 Priimek 2

V opombi pod črto se za slovenske avtorje navede, iz katere ustanove prihajajo. Pri tujih avtorjih je treba navesti tudi ime države.

Naslov Navedbi avtorjev sledi naslov prispevka. Črke v naslovu so velike 16 pik, natiprispevka snjene krepko, besedilo naslova pa poravnano na sredini.

Povzetek Prispevku mora biti dodan povzetek, ki obsega največ 1200 znakov (20 vrstic). Povzetek naj na kratko opredeli temo prispevka, predvsem naj povzame rezultate in ugotovitve. Splošne ugotovitve in misli ne spadajo v povzetek, temveč v uvod.

Povzetek Avtorji morajo oddati tudi prevod povzetka v angleščino. Tudi za prevod povzetka v angleščini velja omejitev do 1200 znakov (20 vrstic).

Ključne Ključne besede (3-5, tudi $\mathrm{v}$ angleškem jeziku) naj bodo natisnjene krepko in $\mathrm{z}$ besede obojestransko poravnavo besedila.

Besedilo Avtorji naj oddajo svoje prispevke na papirju formata A4, s presledkom med vrsticami 1,5 in velikostjo črk 12 pik Arial. Na zgornjem in spodnjem robu naj bo do besedila približno $3 \mathrm{~cm}$, levi rob naj bo širok $2 \mathrm{~cm}$, desni pa $4 \mathrm{~cm}$. Na vsaki strani je tako približno 30 vrstic s približno 62 znaki. Besedilo naj bo obojestransko poravnano, brez umikov na začetku odstavka.

Kratka Avtorji morajo pripraviti kratko predstavitev svojega strokovnega oziroma znanpredstavitev stvenega dela. Predstavitev naj ne presega 600 znakov (10 vrstic, 80 besed). Če avtorjev je avtorjev več, se predstavi vsak posebej, čim bolj zgoščeno. Avtorji naj besedilo umestijo na konec prispevka po navedeni literaturi. 
Struktu- $\quad$ Posamezna poglavja v besedilu naj bodo ločena s samostojnimi podnaslovi in riranje besedila ustrezno oštevilčena (členitev največ na 4 ravni).

Primer:

1 Uvod

2 Naslov poglavja (1. raven)

2.1 Podnaslov (2. raven)

2.1.1 Podnaslov (3. raven)

2.1.1.1 Podnaslov (4. raven)

Oblikovanje V seznamu literature je treba po abecednem redu navesti le avtorje, na katere seznama se sklicujete $\mathrm{v}$ prispevku, celotna oznaka vira pa mora biti skladna s harvardliterature skim načinom navajanja. Če je avtorjev več, navedemo vse, kot so navedeni na izvirnem delu.

Primeri:

a) knjiga:

Priimek, ime (lahko začetnica imena), letnica. Naslov dela. Kraj: Založba.

Na primer:Urlich, W., 1983. Critical Heuristics of Social Planning. Chicago: University of Chicago Press.

b) zbornik:

Samson, C., 1970. Problems of information studies in history. V S. Stone, ur. Humanities information research. Sheffield: CRUS, 1980, str./pp. 44-68. Pri posameznih člankih v zbornikih na koncu posameznega vira navedemo strani, na katerih je članek, na primer:

c) članek v reviji

Kolega, N., 2006. Slovenian coast sea flood risk. Acta geographica Slovenica. 46-2, str. 143-167.

Navajanje Vse reference se začenjajo enako kot pri natisnjenih virih, le da običajnemu delu virov $\mathbf{z}$ interneta sledi še podatek o tem, kje na internetu je bil dokument dobljen in kdaj. Podatek o tem, kdaj je bil dokument dobljen, je pomemben zaradi pogostega spreminjanja www okolja.

Urlich, W., 1983. Critical Heuristics of Social Planning. Chicago: University of Chicago Press, str. 45-100. http://www.mors.si/index.php?id=213, 17. 10. 2008. Pri navajanju zanimivih internetnih naslovov v besedilu (ne gre za navajanje posebnega dokumenta) zadošča navedba naslova (http://www.vpvs.uni-lj.si). Posebna referenca na koncu besedila $\mathrm{v}$ tem primeru ni potrebna. 
Sklicevanje na vire

Slike, diagrami in tabele
Opombe pod črto

Kratice

Format zapisa prispevka
Pri sklicevanju na vire med besedilom navedite le priimek prvega avtorja in letnico izdaje. Primer: ... (Smith, 1997) ...

Če dobesedno navajate del besedila, ga ustrezno označite z narekovaji, v oklepaju pa poleg avtorja in letnice navedite stran besedila, iz katerega ste navajali.

Primer: ... (Smith, 1997, str. 15) ...

Pri povzemanju drugega avtorja napišemo besedilo brez narekovajev, v oklepaju pa napišemo, da gre za povzeto besedilo. Primer: (po Smith, 1997, str. 15). Če avtorja navajamo $\mathrm{v}$ besedilu, $\mathrm{v}$ oklepaju navedemo samo letnico izida in stran (1997, str. 15).

Slike, diagrami in tabele v prispevku naj bodo v posebej pripravljenih datotekah, ki omogočajo lektorske popravke. V besedilu mora biti jasno označeno mesto, kamor je treba vnesti sliko. Skupna dolžina prispevka ne sme preseči dane omejitve.

Če avtor iz tehničnih razlogov grafičnih dodatkov ne more oddati v elektronski obliki, je izjemoma sprejemljivo, da slike priloži besedilu. Avtor mora $\mathrm{v}$ tem primeru na zadnjo stran slike napisati zaporedno številko in naslov, $\mathrm{v}$ besedilu pa pustiti dovolj prostora zanjo. Prav tako mora biti besedilo opremljeno $\mathrm{z}$ naslovom in številčenjem slike. Diagrami se štejejo kot slike. Vse slike in tabele se številčijo. Številčenje poteka enotno in ni povezano s številčenjem poglavij. Naslov slike je naveden pod sliko, naslov tabele pa nad tabelo. Navadno je v besedilu navedeno vsaj eno sklicevanje na sliko ali tabelo. Sklic na sliko ali tabelo je: ... (slika 5) ... (tabela 2) ...

Primer slike: $\quad$ Primer tabele:

Tabela 2: Naslov tabele

Slika 5: Naslov slike

Številčenje opomb pod črto je neodvisno od strukture besedila in se v vsakem prispevku začne s številko 1. Posebej opozarjamo avtorje, da so opombe pod črto namenjene pojasnjevanju misli, zapisanih v besedilu, in ne navajanju literature.

Kratice naj bodo dodane v oklepaju, ko se okrajšana beseda prvič uporabi, zato posebnih seznamov kratic ne dodajamo. Za kratico ali izraz v angleškem jeziku napišemo najprej slovensko ustreznico, v oklepaju pa angleški izvirnik in morebitno angleško kratico.

Uredniški odbor sprejema prispevke, napisane z urejevalnikom besedil MS Word, izjemoma tudi v besedilnem zapisu (text only). 
Naslov Prispevkom naj bosta dodana avtorjeva naslov in internetni naslov ali telefonska avtorja številka, na katerih bo dosegljiv uredniškemu odboru.

Kako poslati Na naslov uredništva ali članov uredniškega odbora je treba poslati tiskano in eleprispevek ktronsko različico prispevka.

Potrjevanje Uredniški odbor avtorju pisno potrdi prejetje prispevka. Avtorjem, ki sporočijo sprejetja tudi naslov svoje elektronske pošte, se potrditev pošlje po tej poti.

prispevka

Korekture Avtor opravi korekture svojega prispevka v treh dneh.

Naslov Ministrstvo za obrambo

uredniškega Generalštab Slovenske vojske

odbora Sodobni vojaški izzivi

Uredniški odbor

Vojkova cesta 55

1000 Ljubljana

Slovenija

Elektronski naslov

Odgovorna urednica:

liliana.brozic@mors.si

Prispevkov, ki ne bodo urejeni skladno s tem navodilom, uredniški odbor ne bo sprejemal. 


\section{INSTRUCTIONS FOR THE AUTHORS OF PAPERS FOR THE CONTEMPORARY MILITARY CHALLENGES AND THE MILITARY EDUCATION JOURNAL}

\section{Content-related instructions}

General The Contemporary Military Challenges is an interdisciplinary scientific expert magazine, which publishes papers on current topics, researches, scientific and expert discussions, technical or social sciences analysis from the field of security, defence and the military..

The Military Education Journal is a military professional and informative publication intended for education and informing on achievements and experiences in the field of military education, training and improvement.

What do we publish?

We publish papers in Slovene with abstracts translated into English. If so decided by the Editorial Board, we also publish papers in English with abstracts translated into Slovene.

We publish papers, which have not been previously published or sent to another magazine for publication. The author is held responsible for all possible copyright violations. If the paper has already been printed elsewhere, sent for publication or presented at an expert conference, the author must notify the editor, obtain the publisher's consent (if necessary) and indicate the reasons for republishing.

\section{Technical instructions}

Limitations The papers should consist of 16 typewritten double-spaced pages or 30,000 charegarding racters. At a minimum they should have 8 pages or 15,000 characters and at a the length of the maximum 24 pages or 45,000 characters.

papers 
Reviews All papers are reviewed. The review is anonymous. With regard to the reviewer's assessment, the Editorial Board or the editor accepts the paper, demands modifications, if necessary, or rejects it. Upon receiving the reviewers' remarks, the author inserts them into the paper.

Due to an anonymous review process, the first page must be designed in the way that the author's identity cannot be recognized.

Next to the title, the author should indicate the category the paper belongs to according to him and according to the classification in the COBISS ${ }^{1}$. The classification is available on the magazine's internet page and at the responsible editor. The Editorial Board determines the final classification.

Proofreading The organizational unit responsible for publishing provides the proofreading of the papers. The proofread papers have to be approved.

Translating The translation of the papers or abstracts is provided by the organizational unit competent for translation or the School of Foreign Languages, Military Schools Centre.

Indicating The authors' name should be written in the upper left corner, aligned left.

the authors Example:

of the paper Name 1 Surname 1,

Name 2 Surname 2,

In the footnote, Slovenian authors should indicate the institution they come from. Foreign authors should also indicate the name of the state they come from.

Title of the The title of the paper is written below the listed authors. The font in the title is paper bold, size 16 points. The text of the title is centrally aligned.

Abstract The paper should have an abstract of a maximum 1,200 characters (20 lines). The abstract should include a short presentation of the topic, particularly the results and the findings. General findings and reflections do not belong in the abstract, but rather in the introduction.

Abstract in The authors must also submit the translation of the abstract into English. The translaEnglish tion of the abstract is likewise limited to a maximum of 1,200 characters (20 lines).

Key words Key words (3-5 also in the English language) should be bold with a justified text alignment.

Text

The authors should submit their papers on an A4 paper format, with 1.5 line spacing, fontArial size 12 points. At the upper and the bottom edge, there should be approx. $3 \mathrm{~cm}$ of space; the left margin should be $2 \mathrm{~cm}$ wide and the right margin $4 \mathrm{~cm}$. Each page consists of approx. 30 lines with 62 characters. The text should have a justified alignment, without indents at the beginning of the paragraphs. 
A brief pre- The authors should prepare a brief presentation of their expert or scientific work. sentation of The presentation should not exceed 600 characters (10 lines, 80 words). If there the authors are several authors, each should be presented individually, as shortly and as comprehensively as possible. These texts should be placed at the end of the paper, after the cited literature.

Text structuring

Individual chapters should be separated with independent subtitles and adequately numbered.

Example:

1 Introduction

2 Title of the chapter $\left(1^{\text {st }}\right.$ level $)$

2.1 Subtitle ( $\left.2^{\text {nd }} l e v e l\right)$

2.1.1 Subtitle $\left(3^{\text {rd }}\right.$ level $)$

2.1.1.1 Subtitle $\left(4^{\text {th }}\right.$ level $)$

Referencing In the bibliography, only the authors of references one refers to in the paper should be listed, in the alphabetical order. The entire reference has to be in compliance with the Harvard citing style.

Example:

Surname, name (can also be the initial of the name), year. Title of the work. Place. Publishing House.

\section{Example:}

Urlich, W., 1983. Critical Heuristics of Social Planning. Chicago: University of Chicago Press.

With certain papers published in journals, the author should indicate, at the end of each reference, a page on which the paper can be found.

\section{Example:}

Urlich, W., 1983. Critical Heuristics of Social Planning. Chicago: University of Chicago Press. pp. 45-100.

Referencing All references start the same as the references for the printed sources, only that internet sources the usual part is followed by the information about the Internet page on which the document was found as well as the date on which it was found. The information about the time that the document was found on the Internet is important, because the WWW environment changes constantly.

Urlich, W., 1983. Critical Heuristics of Social Planning. Chicago: University of Chicago Press. p. 45-100. http://www.mors.si/index.php?id=213, 17 October 2008.

When referencing interesting WWW pages in the text (not citing an individual document) it is enough to state only the Internet address (http://www.vpvs.uni-lj. si). A separate reference at the end of the text is therefore not necessary. 
Citing

Figures, diagrams, tables
When citing sources in the text, indicate only the surname of the author and the year of publication. Example: (Smith, 1997) ...

When making a direct reference to a text, the cited part should be adequately marked with quotation marks and followed by the exact page of the text which the citing is taken from.

Example: ...(Smith, 1997, p.15) ...

Figures, diagrams and tables in the paper should be prepared in separate files which allow for proofreading corrections. The place in the text where the picture should be inserted must be clearly indicated. The total length of the paper must not surpass the given limitation.

Should the author not be able to submit the graphical supplements in the electronic form due to technical reasons, it is exceptionally acceptable to enclose the figures to the text. In this case the author must write a sequence number and a title on the back of each picture and leave enough space in the text to include it. The text must likewise contain the title and the sequence number of the figure. Diagrams are considered figures.

All figures and tables are numbered. The numbering is not uniform and not linked with the numbering of the chapters. The title of the figure is stated beneath it and the title of the table is stated above it.

As a rule, the paper should include at least one reference to a figure or a table.. Reference to a figure or a table is: ... (Figure 5) (Table 2)

Example of a figure: $\quad$ Example of a table:

Table 2: Title of the table

Figure 5: Title of the figure

The numbering of the footnotes is not related to the structure of the text and starts with number 1 in each paper. We want to stress that the aim of the footnotes is to explain the thoughts written in the text and not to reference literature.

Abbreviati- When used for the first time, the abbreviations in the text must be explained in ons parenthesis; therefore no additional list of abbreviations is needed. If the abbreviations or terms are written in English, the appropriate Slovenian term should be written along with the English original and possibly the English abbreviation in the parenthesis.

Format type The Editorial Board accepts only the texts written with a MS Word text editor and of the paper only exceptionally those in the 'text only' format. 
Author's Each paper should include the author's address, e-mail or a telephone number, so address that the Editorial Board can reach him or her.

Sending A print or an electronic version of the paper should be sent to the address of the the paper Editorial Board or the members of the Editorial Board.

Confirma- The Editorial Board sends the author a written confirmation regarding the tion of the reception of the paper. The authors who also list their e-mails receive the confirreception of mation via e-mail.

the paper

Corrections The author makes corrections to the paper within three days.

$\begin{array}{ll}\text { Editorial } & \text { Ministry of Defence } \\ \text { Board } & \text { Slovenian Armed Forces } \\ \text { address } & \text { General Staff } \\ & \text { Contemporary Military Challenges } \\ & \text { Editorial Board } \\ & \text { Vojkova cesta 55 } \\ & \text { 1000 Ljubljana } \\ & \text { Slovenia } \\ & \text { Electronic address: } \\ & \text { Editor in Chief: } \\ & \text { liliana.brozic@mors.si }\end{array}$

The Editorial Board will not accept papers, which will not be in compliance with the above instructions. 


Sodobni vojaški izzivi - 17/št. 4

Vsebina

Liliana Brožič

Igor Kotnik

Viktor Potočnik

Mojca Pešec Uroš Krek

Ivan Žnidar

Branko Podbrežnik
UVODNIK: SLOVENSKA VOJSKA 2012-2014

EDITORIAL: SLOVENIAN ARMED FORCES 2012-2014

PROFESIONALIZACIJA SLOVENSKE VOJSKE - CIU ALI POT

PROFESSIONALIZATION OF THE SLOVENIAN ARMED FORCES - A GOAL OR A PATH

OBSEG IN KARAKTER SLOVENSKE VOJSKE

SLOVENIAN ARMED FORCES SIZE AND CHARACTER

ALI LAHKO PROCES PROFESIONALNEGA VOJAŠKEGA IZOBRAŽEVANJA USTVARI VOJAŠKE STRATEGE?

CAN THE PROCESS OF PROFESSIONAL MILITARY EDUCATION CREATE MILITARY STRATEGISTS?

TRANSFORMACIJSKI IZZIVI ZA VARNOST NA SLOVENSKEM MORJU TRANSFORMATION CHALLENGES TO SAFETY AND SECURITY AT SLOVENIAN SEA

SODELOVANJE SLOVENSKE VOJSKE V MEDNARODNIH OPERACIJAH IN NA MISIJAH V LUČI ZUNANJE POLITIKE REPUBLIKE SLOVENIJE

PARTICIPATION OF THE SLOVENIAN ARMED FORCES IN INTERNATIONAL OPERATIONS AND MISSIONS IN THE LIGHT OF THE FOREIGN POLICY OF THE REPUBLIC OF SLOVENIA 